\title{
The Impact of Obesity on Microglial Function: Immune, Metabolic and Endocrine Perspectives
}

\author{
Vasileia Ismini Alexaki
}

check for updates

Citation: Alexaki, V.I. The Impact of Obesity on Microglial Function: Immune, Metabolic and Endocrine Perspectives. Cells 2021, 10, 1584. https://doi.org/10.3390/cells10071584

Academic Editor: Alessandro Tozzi

Received: 23 May 2021

Accepted: 22 June 2021

Published: 23 June 2021

Publisher's Note: MDPI stays neutral with regard to jurisdictional claims in published maps and institutional affiliations.

Copyright: (C) 2021 by the author. Licensee MDPI, Basel, Switzerland. This article is an open access article distributed under the terms and conditions of the Creative Commons Attribution (CC BY) license (https:// creativecommons.org/licenses/by/ $4.0 /)$.
Institute for Clinical Chemistry and Laboratory Medicine, University Clinic Carl Gustav Carus, TU Dresden, Fetscherstrasse 74, 01307 Dresden, Germany; VasileiaIsmini.Alexaki@uniklinikum-dresden.de; Tel.: +49-351-458-16273

Abstract: Increased life expectancy in combination with modern life style and high prevalence of obesity are important risk factors for development of neurodegenerative diseases. Neuroinflammation is a feature of neurodegenerative diseases, and microglia, the innate immune cells of the brain, are central players in it. The present review discusses the effects of obesity, chronic peripheral inflammation and obesity-associated metabolic and endocrine perturbations, including insulin resistance, dyslipidemia and increased glucocorticoid levels, on microglial function.

Keywords: obesity; microglia; neuroinflammation; neurodegeneration; systemic inflammation; insulin resistance; dyslipidemia; cytokines; leptin; adiponectin; gut microbiome; glucocorticoids

\section{Introduction}

Obesity is a major health problem reaching worldwide pandemic proportions [1,2] It is a result of the modern lifestyle, which is characterized by reduced physical activity and increased energy intake [1,2]. It constitutes an important health challenge as it substantially increases the risk for development of life-threatening conditions, such as type 2 diabetes mellitus, fatty liver disease, atherosclerosis, myocardial infarction and stroke [1,2]. Moreover, mounting evidence links obesity with enhanced cognitive decline during ageing and prevalence for development of neurodegenerative disease [3-9]. Obesity is associated with development of chronic inflammation in the adipose tissue [10], which gradually becomes systemic and may affect other organs, including the brain $[8,11,12]$. Microglia are innate immune cells of the central nervous system (CNS), which can respond to peripheral inflammatory signals and drive neuroinflammation [13-16]. The present review analyzes how obesity may promote microglia-mediated neuroinflammation and associated neurodegeneration through immune, metabolic and endocrine mechanisms. The roles of cytokines, adipokines, lipids, endotoxins and glucocorticoids are presented in this context. Special attention is given to neuroinflammation in the hypothalamus and hippocampus, due to the fundamental roles of these brain regions in whole body metabolism and cognition, respectively.

\section{Microglia in Health and Neurodegenerative Disease}

Microglia are resident immune cells of the CNS $[15,17,18]$. They derive from primitive macrophages of the yolk sac, are long-lived cells and under normal conditions their population is not replenished by peripheral immune cells but sustained through slow selfrenewal [16,19-22]. Their cell population in the adult human and mouse brain is sustained by proliferation and apoptosis $[22,23]$. Microglia from different mouse brain regions display varying proliferative rates, with hippocampal microglia showing higher proliferation than their hypothalamic, cortical, cerebellar or midbrain counterparts [21,22]. Their signature was recently revealed with the help of single-cell approaches, which showed substantial differences between microglia and CNS-resident macrophage populations, as well as brain region- and age-dependent microglial heterogeneity [24-28]. In a healthy state, microglia 
display a unique profile, exemplified by high expression of homeostatic markers, such as Transmembrane Protein 119 (TMEM119), the puringergic receptor P2RY12, sialic acid binding Ig- like lectin H (SIGLECH) and probable G protein coupled receptor 34 (GPR34), which distinguishes them from other myeloid cells [24,29-31]. The adult microglial signature is gender-dependent, with female microglia presenting neuroprotective, while male microglia show rather inflammatory features [32].

Microglia have characteristic long processes, which they continuously extend and retract to scan their environment $[33,34]$. They orchestrate synapse pruning during development, monitor the function of synapses in adulthood and eliminate synaptic connections, the latter requiring 'tagging' of unwanted synapses by complement factors [35-40]. However, synapse elimination is also a hallmark of ageing and neurodegenerative disease, such as Alzheimer's Disease (AD) [40-42]. Moreover, microglia provide trophic support to their neighboring cells by secreting neurotrophic factors, including nerve growth factor (NGF), brain-derived neurotrophic factor (BDNF), fibroblast growth factor (FGF) and Insulin-like Growth Factor (IGF), thereby regulating neuronal function and synapse formation $[29,43,44]$. In turn, NGF and BDNF can regulate microglial functions [13,14,45-48].

Upon acute injury, microglia direct their processes towards the lesion and trigger inflammatory responses in order to restrain the injury or infection [33,34,49-51]. They drive neuroinflammation by sustaining their own and astrocyte inflammatory activation $[52,53]$. For instance, TNF induces its own production, as well as the expression of IL-1 $\beta$, IL-6 and iNOS in microglia [52]. Moreover, TNF, IL-1 $\alpha$ and C1q derived from microglia promote inflammatory activation of a subset of astrocytes, termed A1 astrocytes [53]. A1 astrocytes have lost their ability to promote synapse formation or function, display compromised phagocytic capacity and exert neurotoxic effects [53]. In accordance, A1 astrocytes are abundant in brains of patients with AD, Huntington's disease, Parkinson's Disease (PD), amyotrophic lateral sclerosis (ALS) and multiple sclerosis (MS) [53].

Microglia are the main CNS phagocytes. They remove apoptotic cells and cell debris, which is necessary for resolution of inflammation and tissue repair [54,55]. They phagocytose free myelin, which is present in enhanced amounts in demyelinating disease or ageing $[54,56,57]$; myelin debris clearance is a prerequisite for remyelination and tissue repair [54,57-59]. In addition, they clear amyloid beta $(A \beta)$ peptide; reduced $A \beta$ clearance, commonly observed with advancing age, can sustain chronic microglia-mediated inflammation and drive neurodegeneration [54,60-62]. With advancing age, microglia display impaired phagocytic capacity and accumulate excessive amounts of myelin debris, which leads to cholesterol crystal formation, phagolysosomal membrane rupture and inflammasome activation [54,63-66]. Morphologically they undergo changes exemplified by deramification, amoeboid appearance, spheroid formation and fragmentation, designated as microglial dystrophy $[67,68]$. These microglia have reduced self-renewal capacity and can get dysfunctional or senescent [69-71]. Senescent microglia display increased expression of $\mathrm{p} 16^{\mathrm{Ink} 4 \mathrm{a}}$ and are abundant in neurodegenerative pathologies, while their clearance prevents gliosis and neuropathology [70,71]. In addition, dystrophic or senescent microglia are less efficient in maintaining iron homeostasis and undergo ferroptosis [72,73]. Moreover, aged microglia may become immunologically 'primed', meaning they display increased expression of inflammatory factors and antigen presentation molecules and exhibit an exaggerated inflammatory response to stimuli [74].

In neurodegenerative disease, microglia lose their homeostatic profile and acquire a disease-associated signature (disease-associated microglia, DAM), characterized by enhanced expression of Apolipoprotein E (APOE), AXL, colony-stimulating factor 1 (CSF1), C-Type Lectin Domain Family 7a (CLEC7a), Integrin Subunit Alpha X (ITGAX), Cystatin F (CST7) and Basic Helix-Loop-Helix Family Member E40 (BHLHEe4) [29,75-79]. Moreover, in the context of neurodegenerative disease, microglial responses may be gender-dependent. For instance, in an $\mathrm{AD}$ mouse model female microglia progress faster than male microglia towards an activated state expressing major histocompatibility complex (MHC) type II and AD risk genes [80]. 
Summarizing, although neuroinflammation is a vital and protective response to injury, which is required for tissue regeneration, chronicity of neuroinflammation is destructive for neuronal and glial function and is a feature of neurodegenerative disease [81-84]. Although microglia might not be the initiator of neurodegenerative disease, their passage from a homeostatic to a DAM state, impaired phagocytosis and aberrant inflammation can promote disease development. To which extent microglia might be beneficial, destructive or insufficient to resolve tissue damage and promote regeneration in different neurodegenerative diseases remains unclear.

\section{Microglia Are under the Influence of Peripheral Inflammation}

The central and peripheral innate immune systems are in continuous communication [85]. Peripheral inflammation triggers a stress response by activating the hypothalamicpituitary-adrenal gland (HPA) axis leading to enhanced production of glucocorticoids, in order to impede inflammation $[85,86]$. However, peripheral immune activation can also profoundly affect central immune function. Systemic inflammation induces an innate immune response in the brain, which is usually self-limited due to the activation of strict regulatory mechanisms restraining CNS inflammation [87]. Systemic administration of lipopolysaccharide (LPS), a component of the membrane of gram-negative bacteria, induces in the periphery strong production of pro-inflammatory cytokines, such as TNF and IL-6, which signal through or transpass the blood-brain barrier (BBB) and can target microglia [88-93]. LPS can also trigger cytokine release from BBB endothelial cells [94], while the penetration of LPS through the BBB is minimal [95]. However, a high dose of LPS enhances BBB permeability, especially in the frontal cortex, thalamus, pons-medulla and cerebellum, thereby augmenting the effects of peripheral pro-inflammatory signals in the brain $[96,97]$. In addition, LPS can also affect the brain function through stimulation of the vagal nerve. In turn, vagal nerve stimulation attenuates neuroinflammation and cognitive dysfunction induced by LPS and tilts microglia towards a neuroprotective phenotype potentially through the anti-inflammatory effects of acetylcholine or norepinephrine in microglia [98-102].

LPS strongly reduces microglial expression of homeostatic genes, such as TMEM119, SIGLECH, P2RY12 and GPR34, and phagocytosis-related genes, like Triggering receptor expressed on myeloid cells 2 (TREM2), MER Proto-Oncogene, Tyrosine Kinase (MERTK) and Transforming growth factor beta (TGF $\beta$ ). In contrast, it triggers expression of inflammatory genes, such as IL-1 $\beta$, TNF, IL-23p40, metabolic genes, such as inducible Nitric oxide synthase (iNOS), Phosphofructo-2-kinase/fructose-2,6-biphosphatase 3 (Pfk $\beta 3$ ) and Lactate dehydrogenase A (Ldh $\alpha)$, and anti-inflammatory genes, such as IL-10 [13,91,103]. In fact, distinct microglial activated profiles arise upon acute LPS-induced inflammation, as revealed through single-cell RNA sequencing [103]. Moreover, Wendeln et al. showed that microglia can be trained by a single low dose of peripherally administered LPS to respond more efficiently to a second stimulation with LPS. Microglial training involves epigenetic reprograming, in particular lysine 4 histone 3 methylation (H3K4me1), which persists even 6 months after stimulation. In contrast, three or more doses of LPS induce microglial tolerance. Microglial training promotes, while its tolerance alleviates, AD neuropathology in APP23 mice [91]. However, according to another study, repeated systemic LPS stimulation on four consecutive days maintains brain inflammation and induces loss of dopaminergic neurons in the substantia nigra through activation of the complement system [104].

Changes in microglial signature induced by peripheral inflammation can translate into alterations in neuronal and synaptic functions. For instance, postoperative cognitive dysfunction is associated with microglia-induced neuroinflammation triggered by operation-induced peripheral inflammation [105-107]. TNF, IL- 6 and IL-1 $\beta$ generated by microglia can profoundly affect synaptic transmission and plasticity and underlie cognitive and behavioral alterations occurring in peripheral inflammatory disease [108-112]. Inflammation induced in the gut by intracolonic administration of 2,4,6-trinitrobenzene sulfonic acid (TNBS) significantly reduces synaptic transmission and plasticity in the hippocampus and 
increases pentylenetetrazole-induced seizure susceptibility, while these effects are reversed by TNF neutralization or minocycline-mediated inhibition of microglial activation [111,112].

Acute peripheral inflammation causes sickness behavior, primarily through the function of proinflammatory cytokines (IL-1 $\beta$, TNF and IL-6) in the brain [113]. Long-term peripheral inflammation, such as in autoimmune diseases, systemic infections, cancer or immunotherapy, can lead to development of depression, especially in vulnerable patients or animals with preexisting sickness, due to decompensation of mechanisms regulating sickness behavior [113]. This is associated with HPA axis hyperactivity and glucocorticoid resistance, finally leading to uncontrolled inflammation [86,113]. Moreover, acute and chronic inflammation may aggravate existing neurodegenerative diseases [114-118]. Meta-analyses showed that levels of circulating pro-inflammatory cytokines (TNF, IL-1 $\beta$ and IL-6) are up-regulated in AD patients compared to age-matched control subjects and increased inflammation might even precede the outbreak of the disease [119,120]. Individuals with elevated pro-inflammatory cytokine levels over several decades are particularly prone to development of neurodegeneration $[121,122]$. Sustained presence of inflammatory signals may 'prime' microglia, which then exhibit an exaggerated inflammatory response when exposed to endogenous signals, such as $A \beta$ or myelin [61]. Particularly in the aged brain, systemic inflammation can have detrimental effects [123-125]. Microglia from aged mice exhibit a stronger inflammatory response to peripheral LPS administration compared to microglia from young mice, which is associated with behavioral and cognitive disturbances [123,126-130]. Hence, chronic inflammatory diseases, such as rheumatoid arthritis, osteoarthritis, inflammatory bowel disease, chronic liver disease and type 2 diabetes mellitus, are often accompanied by fatigue, neuropsychiatric disorders such as depression, and cognitive disturbances [131-136].

\section{Obesity-Associated Chronic Peripheral Inflammation}

Obesity is one of the most common causes of chronic low-grade inflammation, which can lead to comorbidities such as type 2 diabetes mellitus and steatohepatitis, significantly impairing life quality $[1,10,137]$. Obesity-associated chronic inflammation in the adipose tissue and other organs, such as the liver, muscle and colon, is linked to metabolic disturbances, including insulin resistance and dyslipidemia, and is therefore termed 'metainflammation' [137-141]. The latter develops predominantly in subjects with increased visceral relative to subcutaneous adiposity [142-144]. In obesity, the adipose tissue undergoes structural, immune and metabolic reprograming [10]. It grows in size through adipocyte hypertrophy and hyperplasia, becomes hypoxic due to its inadequate vascularization and develops chronic inflammation due to secretion of inflammatory factors by adipocytes and immune cells $[10,145,146]$. Hypertrophic adipocytes secrete monocyte chemoattractant protein 1 (MCP1), TNF, IL-6, IL-1 and IL-8, triggering recruitment and inflammatory activation of immune cells [10,147]. Moreover, they secrete a number of pro-inflammatory adipokines, such as leptin, resistin and chemerin [10,147]. Leptin, the best-studied adipokine, regulates food intake and energy expenditure acting on the hypothalamus, while it also triggers pro-inflammatory responses in immune and endothelial cells $[148,149]$. Macrophages play a particularly important role in adipose tissue inflammation $[10,150,151]$. During obesity, macrophages accumulate in the adipose tissue and shift to a pro-inflammatory state, exemplified by increased expression of IL-1 $\beta$, TNF and IL-6 [10,151-153]. In addition, neutrophils, cytotoxic $\mathrm{CD}^{+} \mathrm{T}$ cells and natural killer (NK) cells are recruited to the adipose tissue and promote adipose tissue inflammation $[10,140,150,154]$. Gradually, adipose tissue inflammation becomes systemic, affecting distant organs, such as the liver and muscle $[10,11,137,155,156]$.

Chronic inflammation is associated with development of insulin resistance $[157,158]$. Mechanistically, IL-6 and TNF activate c-Jun N-terminal kinase (JNK) and nuclear factor 'kappa-light-chain-enhancer' of activated B-cells (NF-kB), which can block insulin signaling [158-161]. Consequently, obese subjects display insulin resistance and hyperinsulinemia and are therefore predisposed for development of type 2 diabetes mellitus [156]. 
Chronic inflammation and insulin resistance significantly increase the risk for development of various debilitating conditions, including non-alcoholic steatohepatitis (NASH), cardiovascular disease and neurodegeneration $[10,137,162,163]$.

\section{Obesity and Risk of Neurological Disease}

Several studies have shown that obesity and high dietary fat intake are associated with increased risk of neuropsychiatric, cognitive and neurodegenerative disorders [9,164-166]. Meta-analysis studies showed that individuals with obesity or associated metabolic disorders in midlife have a significantly higher risk for development of dementia or AD later in life $[164,167,168]$. Moreover, numerous studies support a clear link between obesity and cognitive decline [165,169-171]. Obesity-associated comorbidities, including hypertension, type 2 diabetes mellitus and dyslipidemia, can further augment cognitive impairment [165]. Some studies also suggest that obesity in childhood and late adolescence may be a risk factor for MS [172-175]. In addition, epidemiological data strongly support an association between obesity and depression $[166,176]$. This association is stronger in women than men, can already exist in childhood and adolescence and is consistent across Western and non-Western countries $[166,177]$. Moreover, a large analysis showed that obese individuals with metabolic dysregulation are at greater risk for development of depression compared to obese subjects with a favorable metabolic profile [178].

Reduction of gray matter, compromised white matter integrity and lower brain volume, with the hippocampus and the prefrontal cortex being highly affected, are wellreported consequences of obesity or related metabolic perturbations [9,179-182]. Greater neuroinflammation and lower axonal density were also associated with obesity using diffusion basis spectrum imaging [183]. Microglial inflammatory activation is a common denominator of all aforementioned neurological conditions [61,184-187]. In the next paragraphs, mechanisms, which may causally link obesity to microglia-mediated inflammation, especially in the hippocampus and hypothalamus, are discussed (Figures 1 and 2, and Table 1).

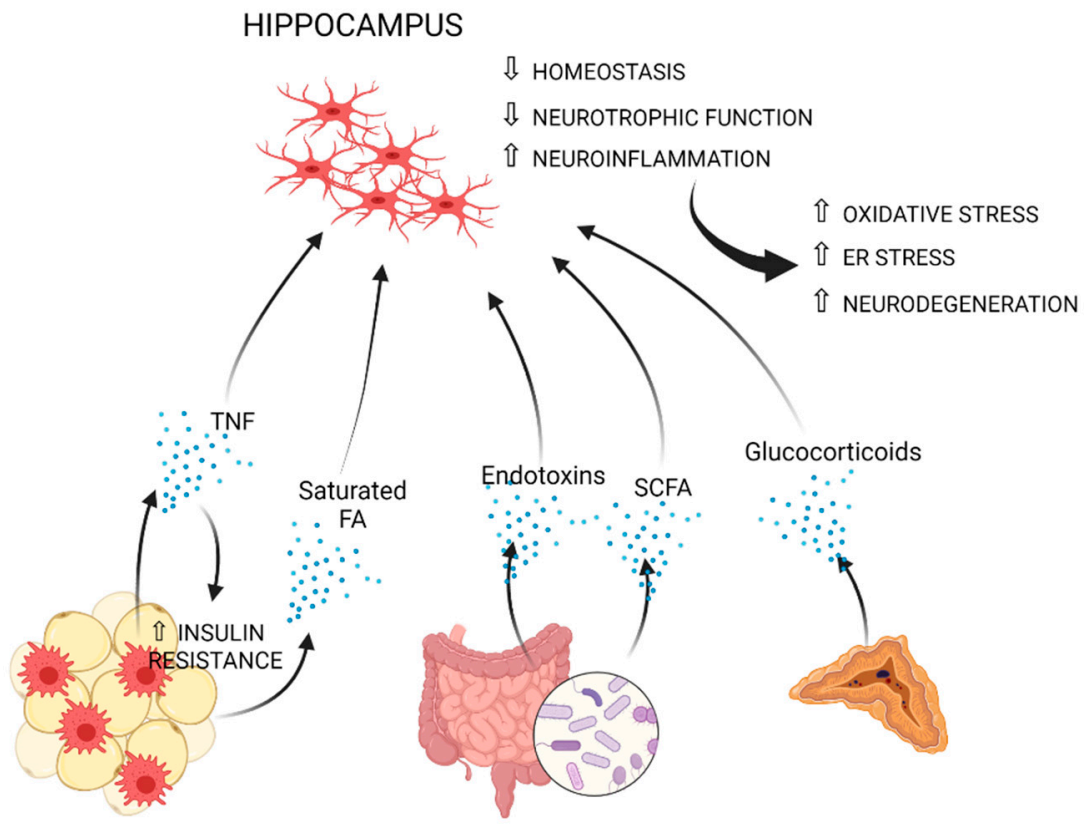

Figure 1. Peripheral immune, metabolic and endocrine routes, which may promote hippocampal microglial inflammation in obesity. Adipose-tissue-derived TNF and saturated fatty acids may exert microglial pro-inflammatory effects in the hippocampus. TNF promotes insulin resistance in the adipose tissue, which leads to enhanced lipolysis, further increasing the amount of saturated fatty acids in the circulation $[10,88,89,140,188]$. Gut microbiome-derived endotoxins and SCFA may also induce hippocampal neuroinflammation $[189,190]$. Chronically enhanced adrenocortical secretion of 
glucocorticoids may sustain microglia-mediated inflammation and neurodegeneration [191-193]. Collectively, these signals can lead to compromised homeostatic and neurotrophic function and sustained inflammatory activation of microglia, associated with oxidative stress, ER stress and neurodegeneration in the hippocampus [193-204].

Table 1. Factors that are discussed as mediators of the effects of obesity on microglia-mediated neuroinflammation.

\begin{tabular}{|c|c|c|c|}
\hline Factor & Cause or Source & Effect on Microglia & References \\
\hline TNF & $\begin{array}{l}\text { Adipose tissue macrophages, } \\
\text { adipocytes }\end{array}$ & Inflammation, reduced phagocytosis & {$[10,52,92,147,205,206]$} \\
\hline Leptin & Adipocytes & $\begin{array}{l}\text { Pro- and anti-inflammatory effects, } \\
\text { ramification }\end{array}$ & {$[10,147,207-210]$} \\
\hline Saturated fatty acids & Diet, adipose tissue & $\begin{array}{l}\text { Inflammation, inflammasome activation, } \\
\text { migration and phagocytosis }\end{array}$ & {$[196,200,211-214]$} \\
\hline Omega-6/omega-3 fatty acids & Diet & $\begin{array}{c}\text { Increased inflammation, decreased } \\
\text { phagocytosis and reduced resolution of } \\
\text { inflammation }\end{array}$ & {$[215-220]$} \\
\hline Endotoxins & Gut microbiome & Inflammation & {$[221,222]$} \\
\hline SCFA & Gut microbiome & Proper microglial function and homeostasis & {$[190,223]$} \\
\hline Glucocorticoids & Adrenal glands & Anti- and pro-inflammatory effects & [191-193,224-230] \\
\hline
\end{tabular}

\section{The Impact of Obesity on Microglia-Mediated Neuroinflammation}

A large number of animal studies has shown that obesity profoundly alters brain plasticity and function. The hippocampus and hypothalamus are extensively studied in this context. High-fat diet (HFD) feeding of juvenile mice decreases neurogenic capacity and leads to defective neuronal connectivity in the dentate gyrus [211]. Obesity also leads to reduced hippocampus-dependent cognitive performance in adult mice and rats [194,195,231-234]. In accordance, obese mice display reduction in long-term potentiation, dendritic spines and sites of excitatory synapses in the hippocampus [194,195,235]. Diet-induced obesity promotes microglial inflammation, while astrocyte density or size are less affected [194,195,235]. Additionally, epididymal fat transplantation from leptin receptor mutant mice $(d b / d b)$, which spontaneously develop obesity, into wild-type mice, causes hippocampal inflammation and disturbances in synaptic function and cognition [236]. Minocycline-mediated inhibition of microglial inflammation prevents dendritic spine loss and cognitive decline in obese mice, underscoring the critical role of microglia in obesityinduced cognitive impairment [195]. Moreover, early-stage obesity in rats interferes with prefrontal and perirhinal cortex-dependent cognitive function, accompanied by synapse and dendritic spine loss [237].

HFD feeding impairs microglial homeostasis in the hippocampus and amygdala. This is marked by increased expression of ionized calcium-binding adapter molecule 1 (IBA-1), CD11b, CD68 and MHCII, and decreased expression of homeostatic markers, including fractalkine and its receptor C-X3-C Motif Chemokine Receptor 1 (CX3CR1), TREM2 and its interactor DAP12 [194-197,238]. High-caloric diet also increases NOD-Like Receptor Protein 3 (NLRP3) expression, indicating inflammasome activation, and IL-1 $\beta$ production in hippocampus and amygdala-derived microglia [196,239]. In accordance, the IL-1 pathway was identified as an early sensor of metabolic changes triggered by overnutrition in adipose tissue macrophages [240]. Moreover, food intake alone triggers production of IL-1 $\beta$ by macrophages, which stimulates pancreatic insulin secretion and promotes inflammation [241]. Along these lines, intracerebral delivery of IL-1 receptor antagonist (IL-1ra) restrains hippocampal inflammation, synaptic dysfunction and cognitive impairment, indicating that IL-1 $\beta$ mediates obesity-associated deterioration of hippocampal function $[236,239]$.

Intriguingly, in obese mice hippocampal microglia display increased synaptic inclusions, suggesting enhanced synaptic engulfment [195]. Partial knockdown of CX3CR1 
or annexin V-treatment both attenuate obesity-associated cognitive decline by preventing microglial activation and phagocytosis, respectively [195]. These findings indicate that microglia drive obesity-associated dendritic spine loss and cognitive impairment through synaptic stripping in a CX3CR1-dependent manner [194,195]. However, a CX3CR1 antagonist reduces NMDA (N-methyl-D-aspartate) receptor subunit (NR2A), AMPA $(\alpha-$ amino-5-methyl-3-hydroxy-4-isoxazole propionate) receptor subunit GluR1, postsynaptic density protein 95 (PSD-95) and BDNF levels in the hippocampus [197]. In turn, impaired BDNF signaling may lead to decreased fractalkine and CX3CR1 expression in the hippocampus [197]. BDNF protein levels are also reduced in the brain cortex and synaptosomal fraction of obese mice, which is accompanied by increased TNF, IL- $1 \beta$ and oxidative stress and decreased mitochondrial respiration in the same regions [242].

Overnutrition leads to endoplasmatic reticulum (ER) stress in whole brain microglia and the hippocampus $[198,240]$. Strikingly, even a short (up to 10 days) period of HFD increases ER stress markers, apoptosis, $A \beta$ and phosphorylated Tau protein levels in the hippocampus of mice [199]. Moreover, high caloric feeding upregulates genes of the heat shock protein (HSP) families HSP70, HSP90 and HSP40 in brain microglia [240]. In vitro, high glucose and palmitate up-regulate ER stress, apoptosis markers and inflammasome activation and down-regulate BDNF and synaptophysin expression in hippocampal cultures, while these effects can be reversed by activation of nuclear factor erythroid 2-related factor 2 (NRF2) [243].

The effects of HFD are exacerbated in aged animals. HFD feeding promotes stronger microglial inflammation and oxidative stress in the hippocampus of old compared to young mice [196,244,245]. In accordance, ageing augments obesity-induced deficits in hippocampal-dependent cognition, reduced synaptic density and impaired long-term potentiation [246]. Old HFD-fed mice also present increased IBA- $1^{+}$microglia numbers in the cerebellum, but not the cortex, compared to young HFD-fed mice [247]. Moreover, HFD feeding aggravates $A \beta$ pathology, Tau phosphorylation, synaptic loss, microglia-mediated inflammation and cognitive deficits in AD mouse models [248-251]. For instance, western diet feeding of APP/PS1 mice increases the amount of TREM2 ${ }^{+}$microglia, which are implicated in AD pathology [245]. As recently shown using $A p p^{N L-F / w t}$ knock-in mice crossed with $o b / o b$ mice, $\mathrm{A} \beta$ deposition shortens the lifespan of obese mice due to dysregulation of microglia and astrocytes [238]. In PD animal models, obese mice display greater dopamine neuron depletion in the substantia nigra and the striatum and increased neuroinflammation compared to lean controls [252,253]. Furthermore, obese animals display enhanced hippocampal neuroinflammation after induction of systemic inflammation [239,254,255]. Collectively, these data suggest that obesity may prime microglia, which upon activation by pro-inflammatory stimuli related to aging, neurodegenerative disease or systemic inflammation, trigger aberrant neuroinflammatory responses.

However, the first brain region affected by HFD feeding is the hypothalamus. In rodents, hypothalamic inflammation evidenced by increased expression of IL-1 $\beta$, IL-6, suppressor of cytokine signaling (SOCS3), inhibitor of NF-kB kinase subunit b (IKBKB), F4/80 and Glial fibrillary acidic protein (GFAP) sets in a few days after HFD feeding start, hence prior to substantial weight gain or development of peripheral inflammation [256-258]. Infusion of glucose or oleic acid in the third ventricle triggers NF- $\mathrm{B}$ activation in the hypothalamus independently of obesity [259]. Microgliosis, astrogliosis, neuronal injury and synapse loss are observed in the hypothalamic arcuate nucleus within the first week of HFD feeding $[257,260,261]$. These early responses subside temporarily, potentially through the activation of neuroprotective mechanisms [257]. However, during long periods of HFD feeding permanent hypothalamic neuroinflammation develops, featured by enhanced numbers of IBA- $1^{+}$microglia, astrogliosis, JNK and NF- $\mathrm{KB}$ activation, increased IL-1 $\beta$, TNF and IL-6 expression, and induction of ER and oxidative stress [212,257-259,262-266]. The hypothalamic inflammatory response is driven by the accumulation and inflammatory activation of microglia in the mediobasal hypothalamus [256,267-269]. Additionally, expression of anti-inflammatory genes, such as IL-10 and CD206, is increased in the hy- 
pothalamus of mice with diet-induced obesity, perhaps in an effort to restrain or resolve inflammation [258]. Moreover, along with chronic inflammation, expression of homeostatic microglial markers, such as P2RY12, TMEM119, SELPLG, SLC2A5 and TREM2, is downregulated in hypothalamic microglia $[258,269]$.

Prolonged inflammation in the hypothalamus instigates apoptosis of hypothalamic neurons and reduction of synaptic inputs, leading to impaired control of energy homeostasis $[257,270,271]$. Consequently, hypothalamic inflammation and injury result in leptin resistance and thus impaired control of food intake, thereby propelling obesity $[263,272]$. Moreover, hypothalamic inflammation promotes development of insulin resistance in the hypothalamus, further deteriorating whole body energy homeostasis [262,263]. Along these lines it was demonstrated that microglial depletion with a CSF1 receptor (CSF1R) inhibitor reduces food intake and body weight gain in HFD-fed mice [269]. Additionally, inhibition of microglial proliferation by intracerebral delivery of the antimitotic drug arabinofuranosyl cytidine dampens hypothalamic inflammation, restores leptin sensitivity and prevents body weight gain in mice [267].

Constitutive neuronal IKK $\beta / \mathrm{NF}-\mathrm{KB}$ activation impairs insulin and leptin signaling in the hypothalamus, consequently increasing food intake and body weight gain in HFD-fed mice, while overexpression of a dominant negative IKK $\beta$ exerts opposite effects [259]. Similarly, microglia-specific inhibition of NF- $\mathrm{KB}$ signaling in $C X 3 C R 1^{\mathrm{CreER}}$; Ikbkbff/ mice reduces food intake and body weight gain upon HFD feeding [269]. Accordingly, mice with microglia-specific deficiency of the NF- $\mathrm{kB}$ negative regulator A20 display increased diet-induced hypothalamic microgliosis, enhanced body weight gain and perturbed whole organism energy expenditure [269]. The effects of hypothalamic IKK $\beta$ are mediated by SOCS3, a potent inhibitor of insulin and leptin signaling [259]. Moreover, JNK inhibition restores insulin signaling in the hypothalamus of obese animals and leads to reduced caloric intake and weight loss [262,263]. Finally, obesity-associated hypothalamic inflammation may also lead to HPA axis dysregulation and consequently stress disorders [273].

In concert with these findings, increased gliosis was demonstrated with magnetic resonance imaging (MRI) in the mediobasal hypothalamus of obese subjects $[257,274,275]$. IBA- $1^{+}$cells show aberrant morphology indicative of microglia dystrophy, characterized by enlarged cell bodies, shortened processes and cytorrhexis, in the hypothalamus of obese individuals compared to normal weight control subjects [258]. Finally, hypothalamic inflammation and damage detected with diffusion tensor imaging are associated with worse cognitive performance in obese individuals [276].

HYPOTHALAMUS

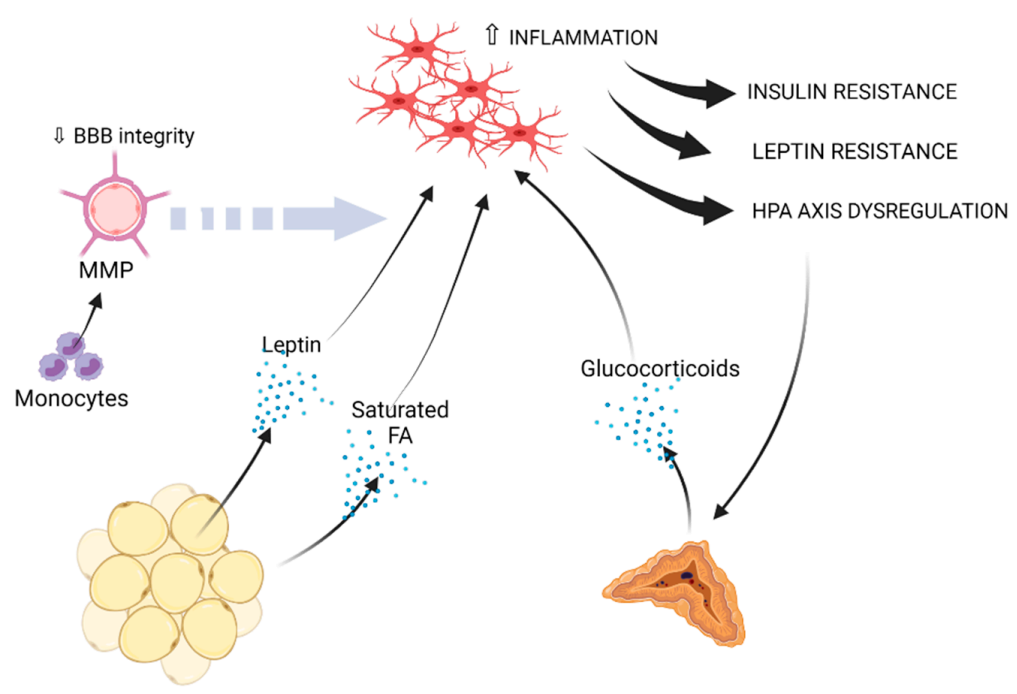

Figure 2. Obesity-induced peripheral immune, metabolic and endocrine factors, which may promote microglia-mediated inflammation in the hypothalamus. Fat-derived leptin and saturated fatty acids 
may promote neuroinflammation in the hypothalamus [212,256,257,259,260,264,266-269,277,278]. Circulating monocytes can drive BBB impairment through MMP production [269,279-282]. Hypothalamic neuroinflammation leads to insulin resistance, leptin resistance and HPA axis dysregulation $[212,256,257,259,260,262-268,272,273]$. Enhanced HPA axis activation drives increased glucocorticoid production by the adrenal gland, which may further sustain microglial inflammation $[283,284]$.

\section{Mechanisms Mediating Obesity-Associated Neuroinflammation}

\subsection{The Impact of Obesity on Blood-Brain Barrier Function}

A dense microcirculatory network ensures appropriate oxygen and nutrient distribution and removal of by-products from the neural tissue. Moreover, it forms the BBB and regulates entry of substances into the brain parenchyma. Hence, microvascular health is critical for brain homeostasis [165]. Cerebromicrovascular dysfunction or damage is an important cause of obesity-associated cognitive decline $[165,285]$. The mechanisms of obesity-associated endothelial disruption leading to cerebrovascular impairment are reviewed elsewhere [165].

The BBB is formed by endothelial cells of the microvessel wall, pericytes, the astrocytic endfeet, the inner vascular and the outer parenchymal basement membrane [286]. Microglial cells are in close connection with the BBB and together with the extracellular matrix they constitute the neurovascular unit [286]. Upon ischemia, microglia in the penumbra associate with blood vessels and engulf endothelial cells, which leads to BBB breakdown and enhanced entrance of blood serum components into the parenchyma [287]. In response to acute systemic inflammation, microglia accumulate around cerebral vessels before changes in BBB permeability are detectable, a contact that is protective for BBB integrity [288]. However, prolonged inflammation drives phagocytosis of the astrocytic endfeet and loss of BBB permeability [288]. Accordingly, LPS-activated microglia reduce the expression of tight junction proteins (zonula occludens-1-, claudin-5-, and occludin-like) through reactive oxygen species (ROS) production in an in vitro BBB model [289].

Several studies suggest that obesity may promote disruption of the BBB [165]. Highenergy-diet consumption leads to reduced expression of tight junction proteins, particularly Claudin-5 and -12 , in the choroid plexus and the BBB, and enhanced BBB permeability in the hippocampus $[290,291]$. Using a mouse model with tdTomato ${ }^{+}$microglia and tdTomato $^{-}$peripheral myeloid cells, Valdearcos et al. showed that mice fed for 4 weeks a HFD display peripherally recruited myeloid cells in the hypothalamus [269]. The same study showed that C-C chemokine receptor type 2 (CCR2) ${ }^{+}$monocytes appear in the mediobasal hypothalamus within the first week of HFD feeding [269]. The percentage of peripheral monocytes and neutrophils, identified as CD11b ${ }^{+}$CD $45^{\text {high }}$ cells, is greater in western diet compared to control diet-fed animals in a CCR2-dependent manner [279]. According to the same study, CD $11 b^{+} C D 45^{\text {high }}$ but not $C D 11 b^{+} C D 45^{\text {low }}$ cells, the latter representing microglia, display a proinflammatory signature, exemplified by high ITGAL, TREM1 and Osteopontin expression [279]. Diabetes mellitus and hypercholesterolemia also increase BBB permeability [292]. BBB integrity can be more strongly impaired in obesity in combination with ageing [244], while certain brain regions, such as the dorsal striatum and subregions of the hippocampus, may be more vulnerable than others [293]. In contrast, according to another study using bone marrow chimeric mice harboring actin-GFP bone marrow, peripheral myeloid cells are not present in the hypothalamus after 20 weeks of HFD feeding [258]. This discrepancy may be due to use of different mouse models, genetic backgrounds, experimental settings or diets in these studies.

Microglia depletion abolishes the recruitment of peripheral myeloid cells in the hypothalamus of HFD-fed mice, suggesting a critical role of microglia in the recruitment of circulating immune cells [269]. BBB disruption facilitates the entry of plasma constituents including IgG and fibrinogen into the brain parenchyma, which may promote microglial inflammatory activation [294,295]. Fibrinogen induces rapid and sustained responses of perivascular microglia through binding to CD11b leading to ROS release and axonal damage $[295,296]$. Moreover, obesity-induced BBB dysfunction is associated with upregulation 
of activating Fc- $\gamma$ receptors, which can interact with $\operatorname{IgG}$ and promote microglia activation in the hippocampus of mice [244]. Activated microglia may cause further BBB impairment, thereby maintaining a vicious cycle of inflammation [280,289].

\subsection{Circulating Monocytes}

Obesity is associated with increased circulating monocyte numbers in humans and mice [297-299]. Mechanistically, the fat-derived alarmins S100A8/A9 locally stimulate macrophage Toll-like Receptor 4 (TLR4) signaling and thereby IL- $1 \beta$ production, which drives myelopoiesis in the bone marrow [297]. Additionally, in metabolically unhealthy obese individuals proinflammatory monocyte counts are increased compared to metabolically healthy obese control subjects [298]. In addition, monocytes acquire a more inflammatory profile in human obesity [300,301]. Hence, more pro-inflammatory monocytes may contribute to systemic and central inflammation in the obese state. Myeloid cells are important producers of matrix metalloproteinases (MMPs) [281,302]. Human macrophages express several MMPs, while murine macrophages predominantly produce MMP-12 and to a lesser extent MMP-9 [303]. Insulin and palmitate can increase MMP-9 expression in human monocytes $[304,305]$. In accordance, MMP-12 expression is up-regulated in the obese adipose tissue and supports nitric oxide synthesis in macrophages [306]. MMPs can promote BBB breakdown through degradation of tight junction and basal lamina proteins and thereby facilitate leukocyte infiltration [282]. Augmented MMP expression is a feature of neuroinflammatory and neurodegenerative disorders, including AD, PD and MS [307]. For instance, monocytes with enhanced MMP-1, $-3,-7$ and -9 mRNA expression are more frequent in MS compared to control patients [308]. Neutrophil-derived MMP-9 destructs type IV collagen, a key component of the BBB in Mycobacterium tuberculosis infection [309]. Leukemic cell-derived MMP-2 and -9 destroy tight junction proteins and thereby increase BBB permeability [310]. Taken together, MMPs secreted by circulating myeloid cells may additionally compromise BBB integrity in obesity.

\subsection{Cytokines}

In obesity, proinflammatory cytokines, such as TNF and IL-6, are produced predominantly by adipose tissue macrophages [10]. In accordance, TNF, IL-6 and IL-18 levels are elevated in the serum of obese compared to non-obese subjects [311-313], while IL-1 $\beta$ serum levels are increased in obese subjects with rheumatoid arthritis compared to nonobese control patients [314]. In addition, type 2 diabetes mellitus strongly correlates with increased serum levels of TNF and IL-6 [311,312]. TNF and IL-6 can affect the CNS either by signaling through their respective receptors on the BBB endothelium or by transpassing the BBB [88-90,315]. Cytokine uptake in the brain may be enhanced in metabolic disease due to reduced BBB integrity [290-292].

TNF skews microglia towards a proinflammatory and less phagocytic phenotype in vitro and in vivo [205]. Alone or in combination with IFN $\gamma$, it increases the expression of inflammatory genes, including C1R, IL-6, iNOS, apoptosis-inducing factor 1 (AIF1), CCR5, CD68, TLR4 and SOCS3, reduces expression of homeostatic genes, such as P2RY12, CX3CR1 and CSF1R, and decreases the expression of phagocytosis-related genes, such as TREM2 and TGFBR1 [92,206,316]. Moreover, it promotes its own production in microglia, thereby sustaining microglial inflammation [92,108]. TNF secreted by microglia mediates endothelial necroptosis, exacerbating BBB breakdown in ischemic stroke [317]. It also targets astrocytes, which then may exert toxic effects on neurons and oligodendrocytes [53]. In addition, TNF directly targets neuronal cells, increasing neuronal injury, CNS excitability and neural precursor apoptosis $[111,318]$.

IL-6 has pleiotropic functions $[319,320]$. Neonatal overnutrition in rats leads to increased IL-6 serum levels and protein amounts in the hypothalamus and cerebellum, without concomitant changes in IL-6 mRNA levels, suggesting an increased uptake of circulating IL-6 [321]. Chronically elevated IL-6 levels in the CNS due to IL-6 overexpression in astrocytes in transgenic mice promotes microglial density, inflammation exemplified by 
increased IL-1 $\beta$, TNF, IL-10, IL-6 and MHCII expression, and neurologic disease [322,323]. Moreover, IL-6-deficient mice are resilient to LPS-induced sickness behavior and do not develop age-associated baseline increase of IL-1 $\beta$ in the hippocampus [93]. However, IL-6-deficient mice develop disturbed carbohydrate and lipid metabolism, leptin resistance and mature-onset obesity, which can be reversed by intracerebroventricular or intrahypothalamic application of IL-6, suggesting an important role of IL-6 in the hypothalamic control of energy intake and metabolism [324,325]. Moreover, exercise-induced increase in IL-6 levels suppresses hyperphagia and hypothalamic inflammation [326] and counteracts the neurotoxic effects of TNF [327]. Finally, IL-6 mediates protective effects of microglia on neurogenesis following injury $[319,328]$.

\subsection{Adipokines}

Leptin is predominantly produced by adipocytes, and its serum levels increase significantly in obesity, which is associated with development of leptin resistance [329,330]. It reaches the brain via direct transport through circumventricular organs, transport through the BBB and uptake into the brain parenchyma and choroid plexus $[329,330]$. In the hypothalamus, it acts in the central melanocortin system, i.e., the pro-opiomelanocortin (POMC) expressing neurons and the neurons producing agouti-related protein (AgRP), regulating hepatic glucose homeostasis, food intake and energy expenditure [329-331]. However, it also contributes to neurogenesis, synaptogenesis and neuronal function [332]. Besides the hypothalamus, leptin receptors are also expressed in the cortex, hippocampus, substantia nigra and other brain regions [332].

Microglial cells express long (active) and short isoforms of leptin receptors [207,332,333]. Leptin modulates the proinflammatory activation of microglia. It increases IL-6 expression through a mechanism involving insulin receptor substrate 1 (IRS-1), AKT, NF- $\mathrm{kB}$ and p300 [208]. It also enhances LPS-induced TNF, IL-1 $\beta$ and macrophage inflammatory protein 2 (MIP2) production in microglia in vitro [209]. However, leptin was also shown to reduce microglial inflammation, increase neuroprotective gene expression and preserve myelin in a spinal cord injury model [210]. Moreover, mice with myeloid cell-specific leptin receptor deficiency display impaired microglial ramification and decreased numbers of hypothalamic neurons, suggesting that leptin signaling is critical for proper microglial activation in the hypothalamus [207]. Mice bearing myeloid cell-specific leptin receptor deficiency are hyperphagic and display increased body weight and fat mass, underscoring the important role of microglial function in hypothalamic neuroendocrine responses [207].

Adiponectin is an adipokine with anti-inflammatory and insulin-sensitizing properties [334]. Its serum levels decrease with obesity, which contributes to development of chronic inflammation and insulin resistance [335]. Low-molecular-weight adiponectin oligomers are detected in the cerebrospinal fluid, and adiponectin receptors are abundantly expressed in the hippocampus and brain cortex [336-339]. Systemically administered adiponectin restrains microglia-mediated inflammation in the hypothalamus during short-term HFD feeding [340]. In accordance, aged adiponectin-deficient mice develop neuroinflammation, $A \beta$ deposition, neuronal loss, central insulin resistance and memory deficits [341]. In addition, adiponectin knockout mice crossed with 5xFAD mice present accelerated amyloid deposition and reduced insulin sensitivity [342]. Moreover, adiponectin suppresses neuroinflammation in mice with corticosterone-induced depression [343,344]. In accordance, globular adiponectin reduces in vivo and in vitro LPS-induced microglial inflammation through an NF- $\mathrm{kB}$-dependent mechanism [345]. Adiponectin also restrains $\mathrm{A} \beta$-induced inflammatory activation and promotes an anti-inflammatory signature in microglia [346,347]. Moreover, adiponectin receptor agonists reduce microglial and astrocyte activation, and restore microglial $\mathrm{A} \beta$ phagocytosis in $\mathrm{AD}$ and intracerebral hemorrhage mouse models, while adiponectin receptor suppression increases amyloidogenesis [342,348-350]. However, whether reduced adiponectin serum levels can account for obesity-associated neuroinflammation remains to be clarified. 


\subsection{Dyslipidemia}

Obesity is associated with alterations in the serum lipidome (dyslipidemia) [351]. Circulating fatty acids are increased in obesity as a result of the enlarged adipose tissue and resistance to the antilipolytic effect of insulin [352,353]. Saturated fatty acids, such as palmitic and stearic acids, trigger inflammatory responses in a number of different cell types, such as monocytes/macrophages, endothelial cells, adipocytes, fibroblasts and smooth and skeletal muscle cells [352]. In humans, a diet rich in palmitate increases plasma IL- 6 and IL-1 $\beta$ levels and potentiates proinflammatory effects of peripheral blood mononuclear cells [354]. Additionally, HFD-fed mice display increased serum levels of saturated fatty acids $[355,356]$. Circulating free fatty acids are taken up by the brain and their uptake is higher in obese compared to non-obese individuals [215,357,358]. For instance, brain uptake and accumulation of palmitate was shown in patients with obesity and metabolic syndrome [357]. Moreover, palmitate levels are increased in the cerebrospinal fluid of overweight and obese subjects with amnestic mild cognitive impairment [359]. In accordance, palmitate levels are elevated in the hypothalamus and hippocampus of HFD-fed mice, and their accumulation can be more pronounced in male than female mice $[196,263,277,358,360,361]$.

Palmitate inhibits leptin signaling in a TLR-Myeloid differentiation primary response 88 (Myd88)-dependent manner [278]. In accordance, TLR4 loss-of-function mutation or intracerebroventricular injection of a TLR4 neutralizing antibody reduces obesity and leptin resistance [212]. Long-chain saturated fatty acids induce in the hypothalamus microglial inflammatory activation, while microglial depletion restores saturated fatty acid-induced leptin signaling impairment [268]. Intracerebroventricular administration of palmitate induces microglial activation and impairs synaptic plasticity in the mouse hippocampus, thereby leading to memory deficits [359]. In vitro, palmitate-treated microglia exhibit increased inflammatory gene expression and impaired migration and phagocytosis [196,211,213]. Mechanistically, saturated fatty acids induce TLR4 activation and downstream JNK signaling [212,214]. Moreover, they induce ER stress by increasing the expression of proteins of the unfolded protein response $[277,362]$. Palmitate also promotes inflammation through the reduction of peroxisome proliferator-activated receptor gamma coactivator 1-alpha (PGC1A) and estrogen receptor $\alpha(\mathrm{ER} \alpha)$ expression [361]. Furthermore, palmitate induces de novo ceramide synthesis in microglia, which in turn promotes inflammasome assembly and IL-1 $\beta$ secretion [200]. Ceramide also promotes TLR4 stabilization and thereby enhances LPS-induced inflammatory signaling [363]. The effects of saturated fatty acids on CNS inflammation may be reversed by unsaturated fatty acids, such as linoleic acid [356].

The brain is particularly enriched with the omega-6 polyunsaturated fatty acid (PUFA) arachidonic acid and the omega-3 PUFA docosahexaenoic acid $[215,216]$. PUFAs are present in the circulation as free fatty acids or as part of lipoproteins esterified to triacylglycerides, phospholipids or cholesteryl esters [216]. They are taken up in the brain through mechanisms, which are little understood $[215,216]$. Once in the brain, PUFAs are metabolized into downstream mediators or incorporated into membrane phospholipids, from which they can be later released [215,364]. PUFAs and their derivatives regulate cell survival, synaptic function, phagocytosis and microglia-mediated inflammation $[215,216]$. In general, an imbalance between omega- 6 and omega- 3 fatty acids resulting from western diet consumption may lead to chronic peripheral and central inflammation [216,365,366]. Many studies have demonstrated that omega-3 PUFAs down-regulate microglial inflammatory activation while promoting phagocytosis and resolution of inflammation [216,366]. In humans, higher omega-3 PUFA consumption is associated with lower risk of neurodegenerative disorders [215,216]. In accordance, western diet feeding increases, while a diet rich in docosahexaenoic acid decreases, amyloid deposition and microglial activation in the hippocampus of AD transgenic mice [217,218]. Moreover, omega-3 PUFAs enhance $\mathrm{A} \beta_{42}$ phagocytosis and decrease inflammation in human microglia [367]. Docosahexaenoic acid reduces surface presentation of TLR4 and CD14, thereby inhibiting LPS-induced downstream signaling and associated proinflammatory responses $[219,220]$. Addition- 
ally, dietary docosapentaenoic acid restrains microglia-mediated neuroinflammation and promotes neuronal survival in AD mouse models [368]. In accordance, omega-3 PUFA supplementation reduces microglial inflammatory activation and mitigates neural tissue destruction after traumatic brain injury $[369,370]$. In addition, docosahexaenoic and eicosapentaenoic acids reduce IFN $\gamma$ - and myelin-induced microglial inflammatory activation, shift microglia to an anti-inflammatory phenotype and promote myelin phagocytosis in the cuprizone-induced demyelination model [371]. In conclusion, in the context of obesity an altered circulating lipidome can shape microglial function. In general, saturated fatty acids and omega-6 PUFAs favor neuroinflammation, while omega-3 PUFAs have anti-inflammatory and pre-resolving properties.

\subsection{Insulin Resistance}

Obesity is associated with hyperinsulinemia and development of peripheral and central insulin resistance $[10,180,372,373]$. In turn, central insulin resistance contributes to dysregulation of peripheral glucose and fat metabolism, thereby accelerating adiposity and associated metabolic disorders [372,374]. Epidemiological studies have shown that type 2 diabetes mellitus significantly increases the risk for cognitive decline or AD development $[116,163,180,375]$. Moreover, a clinical trial showed that moderate hyperinsulinemia induced by insulin infusion triggers an increase in cytokine and $A \beta_{42}$ levels in the cerebrospinal fluid of healthy subjects [376]. In accordance, type 2 diabetes mellitus in overweight and obese individuals is linked to reduced neuronal viability [373].

Obesity-associated insulin resistance promotes amyloid deposition in the Tg2576 AD mouse model [377]. In accordance, mice generated by crossing APP23 mice with diabetic $o b / o b$ or NSY mice display cerebrovascular inflammation and cognitive disturbances [378]. Furthermore, $d b / d b$ mice display microgliosis, increased expression of proinflammatory cytokines and decreased BDNF hippocampal expression compared to control mice $[236,379,380]$. Mouse models of type 2 diabetes mellitus also demonstrate enhanced accumulation of $\alpha$-synuclein and enhanced neuroinflammation when challenged with 1-methyl-4-phenyl-1,2,3,6-tetrahydropyridine (MPTP), a neurotoxin used to mimic cell death caused by PD [381]. In support of these findings, intracerebroventricular injection of insulin increases microglial inflammatory activation and Cyclooxygenase-2 (COX-2)/IL-1 $\beta$ levels in the hippocampus of mice [382]. The effects of insulin in the brain may become even more important in presence of peripheral inflammation since the latter enhances insulin transport into the brain [96]. Finally, macrophages chronically exposed to insulin can become insulin-resistant and display altered inflammatory responses [383]. Whether this holds true in microglia remains to be elucidated.

\subsection{Glucocorticoids}

Glucocorticoid levels may rise in obesity due to HPA axis activation and alterations in adrenocortical function; in turn, increased glucocorticoid levels promote abdominal fat deposition and insulin resistance [191,224,384-386]. HFD-fed, $d b / d b$ and streptozotocintreated mice all display increased corticosterone levels [191,224-227]. Chronically elevated corticosterone levels negatively affect CNS function leading to reduced brain volume, changes in grey and white matter structure, impaired hippocampal neurogenesis, reduced synaptic plasticity, memory deficits and depression-like behavior [201,283,284,387-389]. Although glucocorticoids exert potent anti-inflammatory effects [390], if chronically elevated, they may promote microglia-mediated neuroinflammation [192,193,391-393]. Microglia express glucocorticoid (GR) and mineralcorticoid (MR) receptors, and microglial function is regulated by glucocorticoids [394-397]. Chronic stress driving high corticosterone production leads to increased expression of microglial inflammatory markers, such as TNF, IL-6, IL-1 $\beta$, iNOS, NF-kB and NLRP3, decreased expression of anti-inflammatory markers, including IL-1ra, IL-10, TGF- $\beta$ and Ym1 (chitinase-like protein 3 (Chil3)), oxidative stress, and an enhanced inflammatory response to LPS in the rodent cortex and hippocampus [193,201,392,397,398]. Dexamethasone, a GR agonist, reduces dendritic spine 
density and induces proliferation and activation of microglia in the hippocampus of 3xTgAD mice, while the GR antagonist mifepristone exerts opposite effects [399]. Moreover, stress in early life has lasting effects on microglia-mediated neuroinflammation and may aggravate AD pathology [400,401]. Pharmacological inhibition of corticosterone synthesis with metyrapone restrains microgliosis and decreases TNF and IL- $1 \beta$ expression in the hippocampus of $d b / d b$ mice [402]. Moreover, inhibition of corticosterone action with mifepristone dampens LPS-induced proinflammatory responses and NLRP3 expression in the hippocampus in HFD-fed animals [227]. In addition, adrenalectomy and corticosterone replacement, pharmacological inhibition of glucocorticoid synthesis or lentiviral-mediated GR knockdown in $d b / d b$ mice preserve hippocampal plasticity and learning function by restoring BDNF and TRKB expression in the hippocampus [225,403,404]. These studies collectively suggest that chronic exposure to glucocorticoids may prime microglia leading to enhanced inflammatory responses [396,405-407]. However, mice bearing GR deficiency in macrophages and microglia exhibit exacerbated neuronal damage after intraparenhcymal LPS injection [395]. GR-deficient microglia also display reduced motility, amoeboid morphology and increased proinflammatory activation in a PD animal model or in response to LPS [228-230,395]. These discrepancies could be due to brain region-, dose- or timedependent differences in glucocorticoid effects [408-410], as well as brain region-dependent heterogeneity in microglial subpopulations [28].

\subsection{The Gut-Brain Axis}

Diet-induced obesity is associated with profound changes in the composition and function of the gut microbiome, termed dysbiosis [411,412]. Individuals with a low bacterial richness display more pronounced adiposity, systemic inflammation, insulin resistance and dyslipidemia compared to individuals with high bacterial richness [412]. Diet-induced alterations in the intestinal microbiome contribute to metabolic dysregulation and chronic inflammation in obesity [221,411,413,414]. Germ-free rodents are reported to be resistant to diet-induced obesity and associated insulin resistance [189,415,416] but display perturbed neurogenesis, myelination, BBB function, behavior and cognition [417]. Moreover, obesity is associated with enhanced gut permeability, leading to increased amounts of microbes and immunogenic bacterial products in the circulation $[189,221,418]$. Thus, microbiota can affect the host innate immune system, including microglia via microbial cell components, metabolites and endotoxins [189,190,221]. The intestinal microbiome composition was shown to be decisive for microglial cell proportions, maturation and innate immune responses [190,223]. Antibiotic treatment of mice with diet-induced obesity improves brain insulin signaling, neuroinflammation and depressive-like behavior, effects which are transferable to germ-free animals by fecal transplantation [222]. The effects of gut microbiota on microglia are also mediated by short-chain fatty acids deriving from bacterial fermentation and acting on G-protein coupled receptor 43 (GPR43) [190,223]. Microbiotaaccessible carbohydrates, which prevent dysbiosis and decrease systemic inflammation, suppress microglial inflammatory activation and improve insulin signaling in the hippocampus of obese mice [419]. Roux-en-Y gastric bypass in obese rats leads to beneficial changes in gut microbiota accompanied by improved intestinal integrity; in addition, it improves microglia-mediated hypothalamic inflammation and energy intake control in a gut microbiome-dependent manner [420]. Moreover, probiotic treatment attenuates sickness behavior, microglial inflammatory activation, cerebral monocyte infiltration and TNF serum levels in mice suffering peripheral inflammation [421]. In contrast, a fiber-deficient HFD leads to microbiome alterations, gut barrier impairment and increased hippocampal microglial inflammation, effects that can be reversed by long-term supplementation with $\beta$-glucan [422]. To conclude, alterations in the gut microbiome can critically influence microglia-mediated neuroinflammation and even contribute to the pathogenesis of neurodegenerative diseases [417]. Several neurologic disorders, including AD, PD, MS and major depressive disorder, are associated with altered intestinal microbiota [417,423-425]. 
Hence, obesity-associated dysbiosis may drive disturbed microglial function and development of neurodegenerative conditions.

\section{Conclusions and Future Perspectives}

The effects of obesity are not limited to the periphery but also strongly affect neuronal and innate immune functions in the brain. Circulating immune cells, proinflammatory cytokines, adipokines, dyslipidemia, glucocorticoids and bacterial endotoxins are some of the factors generating a systemic environment unfavorable for microglial homeostatic function. The chronicity of such immune, metabolic and endocrine disturbances can have detrimental effects, as it may drive inflammatory priming, reduce microglial homeostatic functions and eventually exhaust microglia. In the hypothalamus, this can lead to derailment of whole body metabolism and acceleration of metabolic disease, and in the hippocampus or other brain regions to cognitive and mood disorders.

Although the link between metabolic disease and neurodegeneration is well supported by clinical data, less is known on the underlying mechanisms. Recent studies showed that in neurodegenerative disease microglia undergo reprograming from a homeostatic to a disease-associated state $[76,78]$. However, the mechanistic cues driving this transformation remain largely obscure. Moreover, it is not known whether a similar microglial shift also occurs in response to obesity or whether obesity may accelerate such microglial reprograming in response to proinflammatory or neurodegenerative stimuli.

A pallet of single-cell approaches is available today to dissect such phenomena. These technologies can overcome the discrepancies stemming from the heterogeneity between or within microglial or other myeloid cell populations [24-28]. Moreover, development of the CX3CR1 ${ }^{\text {Cre-ERT2 }}, P 2 r y 12^{\text {Cre-ERT2 }}$ and Tmem $119^{\text {Cre-ERT2 }}$ mouse lines facilitate inducible microglia-specific gene deletion [426-428]. However, functional analyses are still hampered by the lack of appropriate in vitro microglia cell culture systems reliably reflecting the in vivo microglial properties. Although in vitro culture conditions can be improved through the addition of TGF- $\beta 2$, IL-34 and cholesterol [429], the homeostatic profile of microglia is severely affected by in vitro culture [24,103]. Instead, ex vivo culture of brain slices more successfully preserves the physiological profile of microglia [430].

Aberrant microglial inflammation is a hallmark of several neurodegenerative disease. However, current knowledge on how to precisely and efficiently target microglia is limited. Complete depletion of microglia through genetic or pharmacological manipulations is possible and was shown to successfully ameliorate the course of neurodegenerative disease by reducing neuroinflammation in several animal studies [431]. For instance, microglia and macrophage removal through CSF1R inhibition improves EAE and cuprizone-induced demyelination [432,433] and prevents cognitive deficits in a model of cranial irradiation [434]. Moreover, in combination with environmental enrichment it reduces adipose tissue and hypothalamic inflammation and improves metabolic outcomes [435]. However, microglia elimination does not prevent or may even exacerbate amyloid pathology in AD mouse models $[436,437]$ and aggravates brain ischemia, PD or coronavirus encephalitis $[50,438,439]$. Detrimental outcomes of microglia elimination in neurodegenerative disease are indicative for the critical role of microglia in resolution of inflammation and regeneration. After depletion, microglial populations are restored through self-renewal [431,440]. Enforced immune repopulation can reset a dysfunctional niche, as shown for Kupffer cells in the liver [441]. Similarly, repopulated microglia may acquire a preresolving function and promote brain tissue recovery [442].

Targeting microglia is challenging due to restriction of drug delivery by the BBB. In this aspect, small lipophilic molecules are promising candidates for microglia targeting. Steroid molecules with neuroprotective and anti-inflammatory properties, such as dehydroepiandrosterone (DHEA) or its derivatives, are especially attractive candidates [13,14,443-445]. Moreover, nanoparticles offer key advantages for drug delivery across the BBB [446]. Microglia targeting can be achieved through incorporation of ligands specific for microglial receptors on the nanoparticle structure [446]. In contrast, targeting of 
systemic factors that mediate peripheral and central inflammation may be less challenging. However, very few peripheral factors mediating microglia-mediated neuroinflammation have been studied in the context of obesity per se. Such studies are important since they could lead to the identification of targets for the management of neuroinflammation in metabolic disease.

Antidiabetic drugs, such thiazolidinediones and metformin, can restrain inflammation, while reduction of hyperglycemia may attenuate monocytosis [10,297]. A large meta-analysis showed that anti-inflammatory treatment effectively reduces symptoms of depression [447]. Furthermore, infliximab, a monoclonal antibody against TNF, exerts antidepressant effects only in patients with higher systemic inflammation and greater BMI [448], the latter pointing to the need of personalized treatments. Moreover, gender differences in microglial responses and occurrence of neurodegenerative diseases should be considered in the context of personalized therapy [80,449]. Finally, due to their applicability, dietary interventions offer attractive possibilities for the prevention of obesity-associated CNS inflammation. Return to a low-fat diet dampens neuroinflammation and restores hippocampal synaptic plasticity and cognition, although it only partially reverses adiposity [194]. Moreover, physical exercise efficiently combats obesity-associated chronic inflammation and may prevent neurodegenerative conditions $[10,450,451]$. Such interventions are safe and may be beneficial for both central and peripheral chronic immunometabolic disorders.

Funding: This work was supported by funds from the Deutsche Forschungsgemeinschaft (SFBTRR 205).

Conflicts of Interest: The author has no conflict of interest to declare.

\section{References}

1. Bluher, M. Obesity: Global epidemiology and pathogenesis. Nat. Rev. Endocrinol. 2019, 15, 288-298. [CrossRef] [PubMed]

2. Heymsfield, S.B.; Wadden, T.A. Mechanisms, pathophysiology, and management of obesity. N. Engl. J. Med. 2017, 376, 254-266. [CrossRef]

3. Kivipelto, M.; Ngandu, T.; Fratiglioni, L.; Viitanen, M.; Kareholt, I.; Winblad, B.; Helkala, E.L.; Tuomilehto, J.; Soininen, H.; Nissinen, A. Obesity and vascular risk factors at midlife and the risk of dementia and Alzheimer disease. Arch. Neurol. 2005, 62, 1556-1560. [CrossRef]

4. Whitmer, R.A.; Gustafson, D.R.; Barrett-Connor, E.; Haan, M.N.; Gunderson, E.P.; Yaffe, K. Central obesity and increased risk of dementia more than three decades later. Neurology 2008, 71, 1057-1064. [CrossRef]

5. Whitmer, R.A.; Gunderson, E.P.; Barrett-Connor, E.; Quesenberry, C.P., Jr.; Yaffe, K. Obesity in middle age and future risk of dementia: A 27 year longitudinal population based study. BMJ 2005, 330, 1360. [CrossRef]

6. Hassing, L.B.; Dahl, A.K.; Thorvaldsson, V.; Berg, S.; Gatz, M.; Pedersen, N.L.; Johansson, B. Overweight in midlife and risk of dementia: A 40-year follow-up study. Int. J. Obes. 2009, 33, 893-898. [CrossRef] [PubMed]

7. Eskelinen, M.H.; Ngandu, T.; Helkala, E.L.; Tuomilehto, J.; Nissinen, A.; Soininen, H.; Kivipelto, M. Fat intake at midlife and cognitive impairment later in life: A population-based CAIDE study. Int. J. Geriatr. Psychiatry 2008, 23, 741-747. [CrossRef]

8. Miller, A.A.; Spencer, S.J. Obesity and neuroinflammation: A pathway to cognitive impairment. Brain Behav. Immun. 2014, 42, 10-21. [CrossRef] [PubMed]

9. O'Brien, P.D.; Hinder, L.M.; Callaghan, B.C.; Feldman, E.L. Neurological consequences of obesity. Lancet Neurol. 2017, 16, 465-477. [CrossRef]

10. Michailidou, Z.; Gomez-Salazar, M.; Alexaki, V.I. Innate immune cells in the adipose tissue in health and metabolic disease. J. Innate Immun. 2021, 1-27. [CrossRef] [PubMed]

11. Nati, M.; Haddad, D.; Birkenfeld, A.L.; Koch, C.A.; Chavakis, T.; Chatzigeorgiou, A. The role of immune cells in metabolismrelated liver inflammation and development of non-alcoholic steatohepatitis (NASH). Rev. Endocrinol. Metab. Disord. 2016, 17, 29-39. [CrossRef] [PubMed]

12. Guillemot-Legris, O.; Muccioli, G.G. Obesity-induced neuroinflammation: Beyond the hypothalamus. Trends Neurosci. 2017, 40, 237-253. [CrossRef] [PubMed]

13. Alexaki, V.I.; Fodelianaki, G.; Neuwirth, A.; Mund, C.; Kourgiantaki, A.; Ieronimaki, E.; Lyroni, K.; Troullinaki, M.; Fujii, C.; Kanczkowski, W.; et al. DHEA inhibits acute microglia-mediated inflammation through activation of the TrkA-Akt1/2-CREBJmjd3 pathway. Mol. Psychiatry 2018, 23, 1410-1420. [CrossRef]

14. Yilmaz, C.; Karali, K.; Fodelianaki, G.; Gravanis, A.; Chavakis, T.; Charalampopoulos, I.; Alexaki, V.I. Neurosteroids as regulators of neuroinflammation. Front. Neuroendocrinol. 2019, 55, 100788. [CrossRef]

15. Prinz, M.; Jung, S.; Priller, J. Microglia biology: One century of evolving concepts. Cell 2019, 179, 292-311. [CrossRef] 
16. Li, Q.; Barres, B.A. Microglia and macrophages in brain homeostasis and disease. Nat. Rev. Immunol. 2018, 18, 225-242. [CrossRef] [PubMed]

17. Bohlen, C.J.; Friedman, B.A.; Dejanovic, B.; Sheng, M. Microglia in brain development, homeostasis, and neurodegeneration. Annu. Rev. Genet. 2019, 53, 263-288. [CrossRef]

18. Eyo, U.B.; Wu, L.J. Microglia: Lifelong patrolling immune cells of the brain. Prog. Neurobiol. 2019, 179, 101614. [CrossRef]

19. Kierdorf, K.; Erny, D.; Goldmann, T.; Sander, V.; Schulz, C.; Perdiguero, E.G.; Wieghofer, P.; Heinrich, A.; Riemke, P.; Holscher, C.; et al. Microglia emerge from erythromyeloid precursors via Pu.1- and Irf8-dependent pathways. Nat. Neurosci. 2013, 16, 273-280. [CrossRef]

20. Huang, Y.; Xu, Z.; Xiong, S.; Sun, F.; Qin, G.; Hu, G.; Wang, J.; Zhao, L.; Liang, Y.X.; Wu, T.; et al. Repopulated microglia are solely derived from the proliferation of residual microglia after acute depletion. Nat. Neurosci. 2018, 21, 530-540. [CrossRef]

21. Fuger, P.; Hefendehl, J.K.; Veeraraghavalu, K.; Wendeln, A.C.; Schlosser, C.; Obermuller, U.; Wegenast-Braun, B.M.; Neher, J.J.; Martus, P.; Kohsaka, S.; et al. Microglia turnover with aging and in an Alzheimer's model via long-term in vivo single-cell imaging. Nat. Neurosci. 2017, 20, 1371-1376. [CrossRef]

22. Tay, T.L.; Mai, D.; Dautzenberg, J.; Fernandez-Klett, F.; Lin, G.; Sagar Datta, M.; Drougard, A.; Stempfl, T.; Ardura-Fabregat, A.; Staszewski, O.; et al. A new fate mapping system reveals context-dependent random or clonal expansion of microglia. Nat. Neurosci. 2017, 20, 793-803. [CrossRef] [PubMed]

23. Askew, K.; Li, K.; Olmos-Alonso, A.; Garcia-Moreno, F.; Liang, Y.; Richardson, P.; Tipton, T.; Chapman, M.A.; Riecken, K.; Beccari, S.; et al. Coupled proliferation and apoptosis maintain the rapid turnover of microglia in the adult brain. Cell Rep. 2017, 18, 391-405. [CrossRef] [PubMed]

24. Butovsky, O.; Jedrychowski, M.P.; Moore, C.S.; Cialic, R.; Lanser, A.J.; Gabriely, G.; Koeglsperger, T.; Dake, B.; Wu, P.M.; Doykan, C.E.; et al. Identification of a unique TGF-beta-dependent molecular and functional signature in microglia. Nat. Neurosci. 2014, 17, 131-143. [CrossRef]

25. Gosselin, D.; Skola, D.; Coufal, N.G.; Holtman, I.R.; Schlachetzki, J.C.M.; Sajti, E.; Jaeger, B.N.; O'Connor, C.; Fitzpatrick, C.; Pasillas, M.P.; et al. An environment-dependent transcriptional network specifies human microglia identity. Science 2017, $356,6344$. [CrossRef] [PubMed]

26. Galatro, T.F.; Holtman, I.R.; Lerario, A.M.; Vainchtein, I.D.; Brouwer, N.; Sola, P.R.; Veras, M.M.; Pereira, T.F.; Leite, R.E.P.; Moller, T.; et al. Transcriptomic analysis of purified human cortical microglia reveals age-associated changes. Nat. Neurosci. 2017, 20, 1162-1171. [CrossRef] [PubMed]

27. Gosselin, D.; Link, V.M.; Romanoski, C.E.; Fonseca, G.J.; Eichenfield, D.Z.; Spann, N.J.; Stender, J.D.; Chun, H.B.; Garner, H.; Geissmann, F.; et al. Environment drives selection and function of enhancers controlling tissue-specific macrophage identities. Cell 2014, 159, 1327-1340. [CrossRef] [PubMed]

28. Grabert, K.; Michoel, T.; Karavolos, M.H.; Clohisey, S.; Baillie, J.K.; Stevens, M.P.; Freeman, T.C.; Summers, K.M.; McColl, B.W. Microglial brain region-dependent diversity and selective regional sensitivities to aging. Nat. Neurosci. 2016, 19, 504-516. [CrossRef] [PubMed]

29. Butovsky, O.; Weiner, H.L. Microglial signatures and their role in health and disease. Nat. Rev. Neurosci. 2018, 19, 622-635. [CrossRef]

30. Bennett, M.L.; Bennett, F.C.; Liddelow, S.A.; Ajami, B.; Zamanian, J.L.; Fernhoff, N.B.; Mulinyawe, S.B.; Bohlen, C.J.; Adil, A.; Tucker, A.; et al. New tools for studying microglia in the mouse and human CNS. Proc. Natl. Acad. Sci. USA 2016, 113, E1738-E1746. [CrossRef] [PubMed]

31. Zrzavy, T.; Hametner, S.; Wimmer, I.; Butovsky, O.; Weiner, H.L.; Lassmann, H. Loss of 'homeostatic' microglia and patterns of their activation in active multiple sclerosis. Brain 2017, 140, 1900-1913. [CrossRef]

32. Villa, A.; Gelosa, P.; Castiglioni, L.; Cimino, M.; Rizzi, N.; Pepe, G.; Lolli, F.; Marcello, E.; Sironi, L.; Vegeto, E.; et al. Sex-specific features of microglia from adult mice. Cell Rep. 2018, 23, 3501-3511. [CrossRef]

33. Davalos, D.; Grutzendler, J.; Yang, G.; Kim, J.V.; Zuo, Y.; Jung, S.; Littman, D.R.; Dustin, M.L.; Gan, W.B. ATP mediates rapid microglial response to local brain injury in vivo. Nat. Neurosci. 2005, 8, 752-758. [CrossRef]

34. Nimmerjahn, A.; Kirchhoff, F.; Helmchen, F. Resting microglial cells are highly dynamic surveillants of brain parenchyma in vivo. Science 2005, 308, 1314-1318. [CrossRef]

35. Miyamoto, A.; Wake, H.; Ishikawa, A.W.; Eto, K.; Shibata, K.; Murakoshi, H.; Koizumi, S.; Moorhouse, A.J.; Yoshimura, Y.; Nabekura, J. Microglia contact induces synapse formation in developing somatosensory cortex. Nat. Commun. 2016, 7, 12540. [CrossRef]

36. Wake, H.; Moorhouse, A.J.; Jinno, S.; Kohsaka, S.; Nabekura, J. Resting microglia directly monitor the functional state of synapses in vivo and determine the fate of ischemic terminals. J. Neurosci. 2009, 29, 3974-3980. [CrossRef]

37. Paolicelli, R.C.; Bolasco, G.; Pagani, F.; Maggi, L.; Scianni, M.; Panzanelli, P.; Giustetto, M.; Ferreira, T.A.; Guiducci, E.; Dumas, L.; et al. Synaptic pruning by microglia is necessary for normal brain development. Science 2011, 333, 1456-1458. [CrossRef]

38. Schafer, D.P.; Lehrman, E.K.; Kautzman, A.G.; Koyama, R.; Mardinly, A.R.; Yamasaki, R.; Ransohoff, R.M.; Greenberg, M.E.; Barres, B.A.; Stevens, B. Microglia sculpt postnatal neural circuits in an activity and complement-dependent manner. Neuron 2012, 74, 691-705. [CrossRef]

39. Stevens, B.; Allen, N.J.; Vazquez, L.E.; Howell, G.R.; Christopherson, K.S.; Nouri, N.; Micheva, K.D.; Mehalow, A.K.; Huberman, A.D.; Stafford, B.; et al. The classical complement cascade mediates CNS synapse elimination. Cell 2007, 131, 1164-1178. [CrossRef] 
40. Stephan, A.H.; Barres, B.A.; Stevens, B. The complement system: An unexpected role in synaptic pruning during development and disease. Annu. Rev. Neurosci. 2012, 35, 369-389. [CrossRef]

41. Selkoe, D.J. Alzheimer's disease is a synaptic failure. Science 2002, 298, 789-791. [CrossRef] [PubMed]

42. Vasek, M.J.; Garber, C.; Dorsey, D.; Durrant, D.M.; Bollman, B.; Soung, A.; Yu, J.; Perez-Torres, C.; Frouin, A.; Wilton, D.K.; et al. A complement-microglial axis drives synapse loss during virus-induced memory impairment. Nature 2016, 534, 538-543. [CrossRef]

43. Parkhurst, C.N.; Yang, G.; Ninan, I.; Savas, J.N.; Yates, J.R., 3rd; Lafaille, J.J.; Hempstead, B.L.; Littman, D.R.; Gan, W.B. Microglia promote learning-dependent synapse formation through brain-derived neurotrophic factor. Cell 2013, 155, 1596-1609. [CrossRef]

44. Kettenmann, H.; Kirchhoff, F.; Verkhratsky, A. Microglia: New roles for the synaptic stripper. Neuron 2013, 77, 10-18. [CrossRef]

45. Fodelianaki, G.; Lansing, F.; Bhattarai, P.; Troullinaki, M.; Zeballos, M.A.; Charalampopoulos, I.; Gravanis, A.; Mirtschink, P.; Chavakis, T.; Alexaki, V.I. Nerve growth factor modulates LPS-induced microglial glycolysis and inflammatory responses. Exp. Cell Res. 2019, 377, 10-16. [CrossRef] [PubMed]

46. Rizzi, C.; Tiberi, A.; Giustizieri, M.; Marrone, M.C.; Gobbo, F.; Carucci, N.M.; Meli, G.; Arisi, I.; D’Onofrio, M.; Marinelli, S.; et al. NGF steers microglia toward a neuroprotective phenotype. Glia 2018, 66, 1395-1416. [CrossRef]

47. Wu, S.Y.; Pan, B.S.; Tsai, S.F.; Chiang, Y.T.; Huang, B.M.; Mo, F.E.; Kuo, Y.M. BDNF reverses aging-related microglial activation. J. Neuroinflamm. 2020, 17, 210. [CrossRef]

48. Harley, S.B.R.; Willis, E.F.; Shaikh, S.N.; Blackmore, D.G.; Sah, P.; Ruitenberg, M.J.; Bartlett, P.F.; Vukovic, J. Selective ablation of BDNF from microglia reveals novel roles in self-renewal and hippocampal neurogenesis. J. Neurosci. 2021, 41, 4172-4186. [CrossRef]

49. Hines, D.J.; Hines, R.M.; Mulligan, S.J.; Macvicar, B.A. Microglia processes block the spread of damage in the brain and require functional chloride channels. Glia 2009, 57, 1610-1618. [CrossRef]

50. Szalay, G.; Martinecz, B.; Lenart, N.; Kornyei, Z.; Orsolits, B.; Judak, L.; Csaszar, E.; Fekete, R.; West, B.L.; Katona, G.; et al. Microglia protect against brain injury and their selective elimination dysregulates neuronal network activity after stroke. Nat. Commun. 2016, 7, 11499. [CrossRef]

51. David, S.; Kroner, A. Repertoire of microglial and macrophage responses after spinal cord injury. Nat. Rev. Neurosci. 2011, 12, 388-399. [CrossRef]

52. Kuno, R.; Wang, J.; Kawanokuchi, J.; Takeuchi, H.; Mizuno, T.; Suzumura, A. Autocrine activation of microglia by tumor necrosis factor-alpha. J. Neuroimmunol. 2005, 162, 89-96. [CrossRef] [PubMed]

53. Liddelow, S.A.; Guttenplan, K.A.; Clarke, L.E.; Bennett, F.C.; Bohlen, C.J.; Schirmer, L.; Bennett, M.L.; Munch, A.E.; Chung, W.S.; Peterson, T.C.; et al. Neurotoxic reactive astrocytes are induced by activated microglia. Nature 2017, 541, 481-487. [CrossRef] [PubMed]

54. Galloway, D.A.; Phillips, A.E.M.; Owen, D.R.J.; Moore, C.S. Phagocytosis in the brain: Homeostasis and disease. Front. Immunol. 2019, 10, 790. [CrossRef]

55. Mike, J.K.; Ferriero, D.M. Efferocytosis mediated modulation of injury after neonatal brain hypoxia-ischemia. Cells 2021, 10, 1025. [CrossRef] [PubMed]

56. Hill, R.A.; Li, A.M.; Grutzendler, J. Lifelong cortical myelin plasticity and age-related degeneration in the live mammalian brain. Nat. Neurosci. 2018, 21, 683-695. [CrossRef]

57. Safaiyan, S.; Kannaiyan, N.; Snaidero, N.; Brioschi, S.; Biber, K.; Yona, S.; Edinger, A.L.; Jung, S.; Rossner, M.J.; Simons, M. Age-related myelin degradation burdens the clearance function of microglia during aging. Nat. Neurosci. 2016, 19, 995-998. [CrossRef]

58. Robinson, S.; Miller, R.H. Contact with central nervous system myelin inhibits oligodendrocyte progenitor maturation. Dev. Biol. 1999, 216, 359-368. [CrossRef]

59. Kotter, M.R.; Li, W.W.; Zhao, C.; Franklin, R.J. Myelin impairs CNS remyelination by inhibiting oligodendrocyte precursor cell differentiation. J. Neurosci. 2006, 26, 328-332. [CrossRef] [PubMed]

60. Mawuenyega, K.G.; Sigurdson, W.; Ovod, V.; Munsell, L.; Kasten, T.; Morris, J.C.; Yarasheski, K.E.; Bateman, R.J. Decreased clearance of CNS beta-amyloid in Alzheimer's disease. Science 2010, 330, 1774. [CrossRef]

61. Heneka, M.T.; Carson, M.J.; El Khoury, J.; Landreth, G.E.; Brosseron, F.; Feinstein, D.L.; Jacobs, A.H.; Wyss-Coray, T.; Vitorica, J.; Ransohoff, R.M.; et al. Neuroinflammation in Alzheimer's disease. Lancet Neurol. 2015, 14, 388-405. [CrossRef]

62. Glass, C.K.; Saijo, K.; Winner, B.; Marchetto, M.C.; Gage, F.H. Mechanisms underlying inflammation in neurodegeneration. Cell 2010, 140, 918-934. [CrossRef] [PubMed]

63. Hefendehl, J.K.; Neher, J.J.; Suhs, R.B.; Kohsaka, S.; Skodras, A.; Jucker, M. Homeostatic and injury-induced microglia behavior in the aging brain. Aging Cell 2014, 13, 60-69. [CrossRef]

64. Sierra, A.; Gottfried-Blackmore, A.C.; McEwen, B.S.; Bulloch, K. Microglia derived from aging mice exhibit an altered inflammatory profile. Glia 2007, 55, 412-424. [CrossRef] [PubMed]

65. Floden, A.M.; Combs, C.K. Microglia demonstrate age-dependent interaction with amyloid-beta fibrils. J. Alzheimers Dis. 2011, 25, 279-293. [CrossRef] [PubMed]

66. Cantuti-Castelvetri, L.; Fitzner, D.; Bosch-Queralt, M.; Weil, M.T.; Su, M.; Sen, P.; Ruhwedel, T.; Mitkovski, M.; Trendelenburg, G.; Lutjohann, D.; et al. Defective cholesterol clearance limits remyelination in the aged central nervous system. Science 2018, 359, 684-688. [CrossRef] 
67. Streit, W.J.; Sammons, N.W.; Kuhns, A.J.; Sparks, D.L. Dystrophic microglia in the aging human brain. Glia 2004, 45, $208-212$. [CrossRef]

68. Savage, J.C.; Carrier, M.; Tremblay, M.E. Morphology of microglia across contexts of health and disease. Methods Mol. Biol. 2019, 2034, 13-26. [PubMed]

69. Streit, W.J. Microglial senescence: Does the brain's immune system have an expiration date? Trends Neurosci. 2006, 29, 506-510. [CrossRef] [PubMed]

70. Bussian, T.J.; Aziz, A.; Meyer, C.F.; Swenson, B.L.; van Deursen, J.M.; Baker, D.J. Clearance of senescent glial cells prevents tau-dependent pathology and cognitive decline. Nature 2018, 562, 578-582. [CrossRef]

71. Streit, W.J.; Braak, H.; Xue, Q.S.; Bechmann, I. Dystrophic (senescent) rather than activated microglial cells are associated with tau pathology and likely precede neurodegeneration in Alzheimer's disease. Acta Neuropathol. 2009, 118, 475-485. [CrossRef]

72. Angelova, D.M.; Brown, D.R. Microglia and the aging brain: Are senescent microglia the key to neurodegeneration? J. Neurochem. 2019, 151, 676-688. [CrossRef] [PubMed]

73. Kapralov, A.A.; Yang, Q.; Dar, H.H.; Tyurina, Y.Y.; Anthonymuthu, T.S.; Kim, R.; St. Croix, C.M.; Mikulska-Ruminska, K.; Liu, B.; Shrivastava, I.H.; et al. Redox lipid reprogramming commands susceptibility of macrophages and microglia to ferroptotic death. Nat. Chem. Biol. 2020, 16, 278-290. [CrossRef]

74. Perry, V.H.; Holmes, C. Microglial priming in neurodegenerative disease. Nat. Rev. Neurol. 2014, 10, 217-224. [CrossRef] [PubMed]

75. Song, W.M.; Colonna, M. The identity and function of microglia in neurodegeneration. Nat. Immunol. 2018, 19, 1048-1058. [CrossRef]

76. Keren-Shaul, H.; Spinrad, A.; Weiner, A.; Matcovitch-Natan, O.; Dvir-Szternfeld, R.; Ulland, T.K.; David, E.; Baruch, K.; LaraAstaiso, D.; Toth, B.; et al. A unique microglia type associated with restricting development of Alzheimer's disease. Cell 2017, 169, 1276-1290.e17. [CrossRef]

77. Jordao, M.J.C.; Sankowski, R.; Brendecke, S.M.; Sagar Locatelli, G.; Tai, Y.H.; Tay, T.L.; Schramm, E.; Armbruster, S.; Hagemeyer, N.; Gross, O.; et al. Single-cell profiling identifies myeloid cell subsets with distinct fates during neuroinflammation. Science 2019, 363, 6425. [CrossRef]

78. Krasemann, S.; Madore, C.; Cialic, R.; Baufeld, C.; Calcagno, N.; El Fatimy, R.; Beckers, L.; O'Loughlin, E.; Xu, Y.; Fanek, Z.; et al. The TREM2-APOE pathway drives the transcriptional phenotype of dysfunctional microglia in neurodegenerative diseases. Immunity 2017, 47, 566-581. [CrossRef] [PubMed]

79. Srinivasan, K.; Friedman, B.A.; Etxeberria, A.; Huntley, M.A.; van der Brug, M.P.; Foreman, O.; Paw, J.S.; Modrusan, Z.; Beach, T.G.; Serrano, G.E.; et al. Alzheimer's patient microglia exhibit enhanced aging and unique transcriptional activation. Cell Rep. 2020, 31, 107843. [CrossRef]

80. Sala Frigerio, C.; Wolfs, L.; Fattorelli, N.; Thrupp, N.; Voytyuk, I.; Schmidt, I.; Mancuso, R.; Chen, W.T.; Woodbury, M.E.; Srivastava, G.; et al. The major risk factors for Alzheimer's disease: Age, sex, and genes modulate the microglia response to abeta plaques. Cell Rep. 2019, 27, 1293-1306.e6. [CrossRef]

81. Ransohoff, R.M. How neuroinflammation contributes to neurodegeneration. Science 2016, 353, 777-783. [CrossRef]

82. Salter, M.W.; Stevens, B. Microglia emerge as central players in brain disease. Nat. Med. 2017, 23, 1018-1027. [CrossRef]

83. Dokalis, N.; Prinz, M. Resolution of neuroinflammation: Mechanisms and potential therapeutic option. Semin. Immunopathol. 2019, 41, 699-709. [CrossRef] [PubMed]

84. Cunha, M.I.; Su, M.; Cantuti-Castelvetri, L.; Muller, S.A.; Schifferer, M.; Djannatian, M.; Alexopoulos, I.; van der Meer, F.; Winkler, A.; van Ham, T.J.; et al. Pro-inflammatory activation following demyelination is required for myelin clearance and oligodendrogenesis. J. Exp. Med. 2020, 217, e20191390. [CrossRef]

85. Dantzer, R. Neuroimmune Interactions: From the brain to the immune system and vice versa. Physiol. Rev. 2018, 98, 477-504. [CrossRef]

86. Chrousos, G.P. The hypothalamic-pituitary-adrenal axis and immune-mediated inflammation. N. Engl. J. Med. 1995, 332, 1351-1362. [CrossRef]

87. Rivest, S. Regulation of innate immune responses in the brain. Nat. Rev. Immunol. 2009, 9, 429-439. [CrossRef]

88. Banks, W.A.; Kastin, A.J.; Broadwell, R.D. Passage of cytokines across the blood-brain barrier. Neuroimmunomodulation 1995, 2, 241-248. [CrossRef]

89. Pan, W.; Kastin, A.J. TNFalpha transport across the blood-brain barrier is abolished in receptor knockout mice. Exp. Neurol. 2002, 174, 193-200. [CrossRef]

90. Blecharz-Lang, K.G.; Wagner, J.; Fries, A.; Nieminen-Kelha, M.; Rosner, J.; Schneider, U.C.; Vajkoczy, P. Interleukin 6-mediated endothelial barrier disturbances can be attenuated by blockade of the IL6 receptor expressed in brain microvascular endothelial cells. Transl. Stroke Res. 2018, 9, 631-642. [CrossRef]

91. Wendeln, A.C.; Degenhardt, K.; Kaurani, L.; Gertig, M.; Ulas, T.; Jain, G.; Wagner, J.; Hasler, L.M.; Wild, K.; Skodras, A.; et al. Innate immune memory in the brain shapes neurological disease hallmarks. Nature 2018, 556, 332-338. [CrossRef]

92. Bras, J.P.; Bravo, J.; Freitas, J.; Barbosa, M.A.; Santos, S.G.; Summavielle, T.; Almeida, M.I. TNF-alpha-induced microglia activation requires miR-342: Impact on NF-kB signaling and neurotoxicity. Cell Death Dis. 2020, 11, 415. [CrossRef]

93. Garner, K.M.; Amin, R.; Johnson, R.W.; Scarlett, E.J.; Burton, M.D. Microglia priming by interleukin-6 signaling is enhanced in aged mice. J. Neuroimmunol. 2018, 324, 90-99. [CrossRef] 
94. Verma, S.; Nakaoke, R.; Dohgu, S.; Banks, W.A. Release of cytokines by brain endothelial cells: A polarized response to lipopolysaccharide. Brain Behav. Immun. 2006, 20, 449-455. [CrossRef]

95. Banks, W.A.; Robinson, S.M. Minimal penetration of lipopolysaccharide across the murine blood-brain barrier. Brain Behav. Immun. 2010, 24, 102-109. [CrossRef]

96. Xaio, H.; Banks, W.A.; Niehoff, M.L.; Morley, J.E. Effect of LPS on the permeability of the blood-brain barrier to insulin. Brain Res. 2001, 896, 36-42. [CrossRef]

97. Banks, W.A.; Gray, A.M.; Erickson, M.A.; Salameh, T.S.; Damodarasamy, M.; Sheibani, N.; Meabon, J.S.; Wing, E.E.; Morofuji, Y.; Cook, D.G.; et al. Lipopolysaccharide-induced blood-brain barrier disruption: Roles of cyclooxygenase, oxidative stress, neuroinflammation, and elements of the neurovascular unit. J. Neuroinflamm. 2015, 12, 223. [CrossRef]

98. Hoover, D.B. Cholinergic modulation of the immune system presents new approaches for treating inflammation. Pharmacol. Ther. 2017, 179, 1-16. [CrossRef] [PubMed]

99. Ano, Y.; Ohya, R.; Yamazaki, T.; Takahashi, C.; Taniguchi, Y.; Kondo, K.; Takashima, A.; Uchida, K.; Nakayama, H. Hop bitter acids containing a beta-carbonyl moiety prevent inflammation-induced cognitive decline via the vagus nerve and noradrenergic system. Sci. Rep. 2020, 10, 20028. [CrossRef]

100. Huffman, W.J.; Subramaniyan, S.; Rodriguiz, R.M.; Wetsel, W.C.; Grill, W.M.; Terrando, N. Modulation of neuroinflammation and memory dysfunction using percutaneous vagus nerve stimulation in mice. Brain Stimul. 2019, 12, 19-29. [CrossRef] [PubMed]

101. Kaczmarczyk, R.; Tejera, D.; Simon, B.J.; Heneka, M.T. Microglia modulation through external vagus nerve stimulation in a murine model of Alzheimer's disease. J. Neurochem. 2017. [CrossRef] [PubMed]

102. Frasch, M.G.; Szynkaruk, M.; Prout, A.P.; Nygard, K.; Cao, M.; Veldhuizen, R.; Hammond, R.; Richardson, B.S. Decreased neuroinflammation correlates to higher vagus nerve activity fluctuations in near-term ovine fetuses: A case for the afferent cholinergic anti-inflammatory pathway? J. Neuroinflamm. 2016, 13, 103. [CrossRef] [PubMed]

103. Sousa, C.; Golebiewska, A.; Poovathingal, S.K.; Kaoma, T.; Pires-Afonso, Y.; Martina, S.; Coowar, D.; Azuaje, F.; Skupin, A.; Balling, R.; et al. Single-cell transcriptomics reveals distinct inflammation-induced microglia signatures. EMBO Rep. 2018, 19, e46171. [CrossRef] [PubMed]

104. Bodea, L.G.; Wang, Y.; Linnartz-Gerlach, B.; Kopatz, J.; Sinkkonen, L.; Musgrove, R.; Kaoma, T.; Muller, A.; Vallar, L.; Di Monte, D.A.; et al. Neurodegeneration by activation of the microglial complement-phagosome pathway. J. Neurosci. 2014, 34, 8546-8556. [CrossRef]

105. Forsberg, A.; Cervenka, S.; Jonsson Fagerlund, M.; Rasmussen, L.S.; Zetterberg, H.; Erlandsson Harris, H.; Stridh, P.; Christensson, E.; Granstrom, A.; Schening, A.; et al. The immune response of the human brain to abdominal surgery. Ann. Neurol. 2017, 81, 572-582. [CrossRef] [PubMed]

106. Li, T.; Liu, T.; Chen, X.; Li, L.; Feng, M.; Zhang, Y.; Wan, L.; Zhang, C.; Yao, W. Microglia induce the transformation of A1/A2 reactive astrocytes via the CXCR7/PI3K/Akt pathway in chronic post-surgical pain. J. Neuroinflamm. 2020, 17, 211. [CrossRef] [PubMed]

107. Chen, Y.N.; Sha, H.H.; Wang, Y.W.; Zhou, Q.; Bhuiyan, P.; Li, N.N.; Qian, Y.N.; Dong, H.Q. Histamine 2/3 receptor agonists alleviate perioperative neurocognitive disorders by inhibiting microglia activation through the PI3K/AKT/FoxO1 pathway in aged rats. J. Neuroinflamm. 2020, 17, 217. [CrossRef]

108. Raffaele, S.; Lombardi, M.; Verderio, C.; Fumagalli, M. TNF production and release from microglia via extracellular vesicles: Impact on brain functions. Cells 2020, 9, 2145. [CrossRef]

109. Rizzo, F.R.; Musella, A.; de Vito, F.; Fresegna, D.; Bullitta, S.; Vanni, V.; Guadalupi, L.; Stampanoni Bassi, M.; Buttari, F.; Mandolesi, G.; et al. Tumor necrosis factor and interleukin-1beta modulate synaptic plasticity during neuroinflammation. Neural Plast. 2018, 2018, 8430123. [CrossRef]

110. Nelson, T.E.; Olde Engberink, A.; Hernandez, R.; Puro, A.; Huitron-Resendiz, S.; Hao, C.; de Graan, P.N.; Gruol, D.L. Altered synaptic transmission in the hippocampus of transgenic mice with enhanced central nervous systems expression of interleukin-6. Brain Behav. Immun. 2012, 26, 959-971. [CrossRef]

111. Riazi, K.; Galic, M.A.; Kuzmiski, J.B.; Ho, W.; Sharkey, K.A.; Pittman, Q.J. Microglial activation and TNFalpha production mediate altered CNS excitability following peripheral inflammation. Proc. Natl. Acad. Sci. USA 2008, 105, 17151-17156. [CrossRef]

112. Riazi, K.; Galic, M.A.; Kentner, A.C.; Reid, A.Y.; Sharkey, K.A.; Pittman, Q.J. Microglia-dependent alteration of glutamatergic synaptic transmission and plasticity in the hippocampus during peripheral inflammation. J. Neurosci. 2015, 35, $4942-4952$. [CrossRef]

113. Dantzer, R.; O'Connor, J.C.; Freund, G.G.; Johnson, R.W.; Kelley, K.W. From inflammation to sickness and depression: When the immune system subjugates the brain. Nat. Rev. Neurosci. 2008, 9, 46-56. [CrossRef] [PubMed]

114. Ferrari, C.C.; Tarelli, R. Parkinson's disease and systemic inflammation. Parkinsons Dis. 2011, 2011, 436813. [CrossRef]

115. Culibrk, R.A.; Hahn, M.S. The role of chronic inflammatory bone and joint disorders in the pathogenesis and progression of Alzheimer's disease. Front. Aging Neurosci. 2020, 12, 583884. [CrossRef] [PubMed]

116. Diniz Pereira, J.; Gomes Fraga, V.; Morais Santos, A.L.; Carvalho, M.D.G.; Caramelli, P.; Braga Gomes, K. Alzheimer's disease and type 2 diabetes mellitus: A systematic review of proteomic studies. J. Neurochem. 2021, 156, 753-776. [CrossRef]

117. Hayden, M.R. Type 2 diabetes mellitus increases the risk of late-onset Alzheimer's disease: Ultrastructural remodeling of the neurovascular unit and diabetic gliopathy. Brain Sci. 2019, 9, 262. [CrossRef] 
118. Kempuraj, D.; Thangavel, R.; Selvakumar, G.P.; Zaheer, S.; Ahmed, M.E.; Raikwar, S.P.; Zahoor, H.; Saeed, D.; Natteru, P.A.; Iyer, S.; et al. Brain and peripheral atypical inflammatory mediators potentiate neuroinflammation and neurodegeneration. Front. Cell Neurosci. 2017, 11, 216. [CrossRef]

119. Walker, K.A.; Ficek, B.N.; Westbrook, R. Understanding the role of systemic inflammation in Alzheimer's disease. ACS Chem. Neurosci. 2019, 10, 3340-3342. [CrossRef]

120. Park, J.C.; Han, S.H.; Mook-Jung, I. Peripheral inflammatory biomarkers in Alzheimer's disease: A brief review. BMB Rep. 2020, 53, 10-19. [CrossRef]

121. Walker, K.A.; Hoogeveen, R.C.; Folsom, A.R.; Ballantyne, C.M.; Knopman, D.S.; Windham, B.G.; Jack, C.R., Jr.; Gottesman, R.F. Midlife systemic inflammatory markers are associated with late-life brain volume: The ARIC study. Neurology 2017, 89, 2262-2270. [CrossRef]

122. Walker, K.A.; Windham, B.G.; Power, M.C.; Hoogeveen, R.C.; Folsom, A.R.; Ballantyne, C.M.; Knopman, D.S.; Selvin, E.; Jack, C.R., Jr.; Gottesman, R.F. The association of mid-to late-life systemic inflammation with white matter structure in older adults: The atherosclerosis risk in communities study. Neurobiol. Aging 2018, 68, 26-33. [CrossRef]

123. Hoeijmakers, L.; Heinen, Y.; van Dam, A.M.; Lucassen, P.J.; Korosi, A. Microglial priming and Alzheimer's disease: A possible role for (early) immune challenges and epigenetics? Front. Hum. Neurosci. 2016, 10, 398. [CrossRef]

124. Dilger, R.N.; Johnson, R.W. Aging, microglial cell priming, and the discordant central inflammatory response to signals from the peripheral immune system. J. Leuk. Biol. 2008, 84, 932-939. [CrossRef] [PubMed]

125. Sparkman, N.L.; Johnson, R.W. Neuroinflammation associated with aging sensitizes the brain to the effects of infection or stress. Neuroimmunomodulation 2008, 15, 323-330. [CrossRef]

126. Barrientos, R.M.; Higgins, E.A.; Biedenkapp, J.C.; Sprunger, D.B.; Wright-Hardesty, K.J.; Watkins, L.R.; Rudy, J.W.; Maier, S.F. Peripheral infection and aging interact to impair hippocampal memory consolidation. Neurobiol. Aging 2006, 27, 723-732. [CrossRef]

127. Godbout, J.P.; Moreau, M.; Lestage, J.; Chen, J.; Sparkman, N.L.; O'Connor, J.; Castanon, N.; Kelley, K.W.; Dantzer, R.; Johnson, R.W. Aging exacerbates depressive-like behavior in mice in response to activation of the peripheral innate immune system. Neuropsychopharmacology 2008, 33, 2341-2351. [CrossRef] [PubMed]

128. Godbout, J.P.; Chen, J.; Abraham, J.; Richwine, A.F.; Berg, B.M.; Kelley, K.W.; Johnson, R.W. Exaggerated neuroinflammation and sickness behavior in aged mice following activation of the peripheral innate immune system. FASEB J. 2005, 19, 1329-1331. [CrossRef] [PubMed]

129. Henry, C.J.; Huang, Y.; Wynne, A.M.; Godbout, J.P. Peripheral lipopolysaccharide (LPS) challenge promotes microglial hyperactivity in aged mice that is associated with exaggerated induction of both pro-inflammatory IL-1beta and anti-inflammatory IL-10 cytokines. Brain Behav. Immun. 2009, 23, 309-317. [CrossRef]

130. Chen, J.; Buchanan, J.B.; Sparkman, N.L.; Godbout, J.P.; Freund, G.G.; Johnson, R.W. Neuroinflammation and disruption in working memory in aged mice after acute stimulation of the peripheral innate immune system. Brain Behav. Immun. 2008, 22, 301-311. [CrossRef]

131. Schrepf, A.; Kaplan, C.M.; Ichesco, E.; Larkin, T.; Harte, S.E.; Harris, R.E.; Murray, A.D.; Waiter, G.D.; Clauw, D.J.; Basu, N. A multi-modal MRI study of the central response to inflammation in rheumatoid arthritis. Nat. Commun. 2018, 9, 2243. [CrossRef]

132. Kyrkanides, S.; Tallents, R.H.; Miller, J.N.; Olschowka, M.E.; Johnson, R.; Yang, M.; Olschowka, J.A.; Brouxhon, S.M.; O’Banion, M.K. Osteoarthritis accelerates and exacerbates Alzheimer's disease pathology in mice. J. Neuroinflamm. 2011, 8, 112. [CrossRef]

133. Suss, P.; Rothe, T.; Hoffmann, A.; Schlachetzki, J.C.M.; Winkler, J. The joint-brain axis: Insights from rheumatoid arthritis on the crosstalk between chronic peripheral inflammation and the brain. Front. Immunol. 2020, 11, 612104. [CrossRef]

134. Hauser, W.; Janke, K.H.; Klump, B.; Hinz, A. Anxiety and depression in patients with inflammatory bowel disease: Comparisons with chronic liver disease patients and the general population. Inflamm. Bowel Dis. 2011, 17, 621-632. [CrossRef]

135. D'Mello, C.; Swain, M.G. Liver-brain interactions in inflammatory liver diseases: Implications for fatigue and mood disorders. Brain Behav. Immun. 2014, 35, 9-20. [CrossRef]

136. Lasselin, J.; Laye, S.; Dexpert, S.; Aubert, A.; Gonzalez, C.; Gin, H.; Capuron, L. Fatigue symptoms relate to systemic inflammation in patients with type 2 diabetes. Brain Behav. Immun. 2012, 26, 1211-1219. [CrossRef]

137. Saltiel, A.R.; Olefsky, J.M. Inflammatory mechanisms linking obesity and metabolic disease. J. Clin. Investig. 2017, 127, 1-4. [CrossRef]

138. Li, C.; Xu, M.M.; Wang, K.; Adler, A.J.; Vella, A.T.; Zhou, B. Macrophage polarization and meta-inflammation. Transl. Res. 2018, 191, 29-44. [CrossRef]

139. Alexaki, V.I.; Chavakis, T. The role of innate immunity in the regulation of brown and beige adipogenesis. Rev. Endocrinol. Metab. Disord. 2016, 17, 41-49. [CrossRef]

140. Chmelar, J.; Chung, K.J.; Chavakis, T. The role of innate immune cells in obese adipose tissue inflammation and development of insulin resistance. Thromb. Haemost. 2013, 109, 399-406.

141. Brestoff, J.R.; Artis, D. Immune regulation of metabolic homeostasis in health and disease. Cell 2015, 161, 146-160. [CrossRef] [PubMed]

142. Cancello, R.; Tordjman, J.; Poitou, C.; Guilhem, G.; Bouillot, J.L.; Hugol, D.; Coussieu, C.; Basdevant, A.; Bar Hen, A.; Bedossa, P.; et al. Increased infiltration of macrophages in omental adipose tissue is associated with marked hepatic lesions in morbid human obesity. Diabetes 2006, 55, 1554-1561. [CrossRef] 
143. Harman-Boehm, I.; Bluher, M.; Redel, H.; Sion-Vardy, N.; Ovadia, S.; Avinoach, E.; Shai, I.; Kloting, N.; Stumvoll, M.; Bashan, N.; et al. Macrophage infiltration into omental versus subcutaneous fat across different populations: Effect of regional adiposity and the comorbidities of obesity. J. Clin. Endocrinol. Metab. 2007, 92, 2240-2247. [CrossRef] [PubMed]

144. Stefan, N.; Haring, H.U.; Hu, F.B.; Schulze, M.B. Metabolically healthy obesity: Epidemiology, mechanisms, and clinical implications. Lancet Diabetes Endocrinol. 2013, 1, 152-162. [CrossRef]

145. Ghaben, A.L.; Scherer, P.E. Adipogenesis and metabolic health. Nat. Rev. Mol. Cell Biol. 2019, 20, 242-258. [CrossRef] [PubMed]

146. Spalding, K.L.; Arner, E.; Westermark, P.O.; Bernard, S.; Buchholz, B.A.; Bergmann, O.; Blomqvist, L.; Hoffstedt, J.; Naslund, E.; Britton, T.; et al. Dynamics of fat cell turnover in humans. Nature 2008, 453, 783-787. [CrossRef]

147. Fasshauer, M.; Bluher, M. Adipokines in health and disease. Trends Pharmacol. Sci. 2015, 36, 461-470. [CrossRef]

148. Mancuso, P. The role of adipokines in chronic inflammation. Immunotargets Ther. 2016, 5, 47-56. [CrossRef]

149. Pan, W.W.; Myers, M.G., Jr. Leptin and the maintenance of elevated body weight. Nat. Rev. Neurosci. 2018, 19, 95-105. [CrossRef]

150. Chung, K.J.; Nati, M.; Chavakis, T.; Chatzigeorgiou, A. Innate immune cells in the adipose tissue. Rev. Endocrinol. Metab. Disord. 2018, 19, 283-292. [CrossRef] [PubMed]

151. Hill, A.A.; Reid Bolus, W.; Hasty, A.H. A decade of progress in adipose tissue macrophage biology. Immunol. Rev. 2014, 262, 134-152. [CrossRef] [PubMed]

152. Chung, K.J.; Chatzigeorgiou, A.; Economopoulou, M.; Garcia-Martin, R.; Alexaki, V.I.; Mitroulis, I.; Nati, M.; Gebler, J.; Ziemssen, T.; Goelz, S.E.; et al. A self-sustained loop of inflammation-driven inhibition of beige adipogenesis in obesity. Nat. Immunol. 2017, 18, 654-664. [CrossRef] [PubMed]

153. Lumeng, C.N.; Bodzin, J.L.; Saltiel, A.R. Obesity induces a phenotypic switch in adipose tissue macrophage polarization. J. Clin. Investig. 2007, 117, 175-184. [CrossRef] [PubMed]

154. Chatzigeorgiou, A.; Karalis, K.P.; Bornstein, S.R.; Chavakis, T. Lymphocytes in obesity-related adipose tissue inflammation. Diabetologia 2012, 55, 2583-2592. [CrossRef]

155. Wu, H.; Ballantyne, C.M. Skeletal muscle inflammation and insulin resistance in obesity. J. Clin. Investig. 2017, 127, 43-54. [CrossRef]

156. Czech, M.P. Insulin action and resistance in obesity and type 2 diabetes. Nat. Med. 2017, 23, 804-814. [CrossRef]

157. Samuel, V.T.; Shulman, G.I. The pathogenesis of insulin resistance: Integrating signaling pathways and substrate flux. J. Clin. Investig. 2016, 126, 12-22. [CrossRef]

158. Sabio, G.; Das, M.; Mora, A.; Zhang, Z.; Jun, J.Y.; Ko, H.J.; Barrett, T.; Kim, J.K.; Davis, R.J. A stress signaling pathway in adipose tissue regulates hepatic insulin resistance. Science 2008, 322, 1539-1543. [CrossRef]

159. Hirosumi, J.; Tuncman, G.; Chang, L.; Gorgun, C.Z.; Uysal, K.T.; Maeda, K.; Karin, M.; Hotamisligil, G.S. A central role for JNK in obesity and insulin resistance. Nature 2002, 420,333-336. [CrossRef]

160. Uysal, K.T.; Wiesbrock, S.M.; Marino, M.W.; Hotamisligil, G.S. Protection from obesity-induced insulin resistance in mice lacking TNF-alpha function. Nature 1997, 389, 610-614. [CrossRef]

161. Xu, H.; Barnes, G.T.; Yang, Q.; Tan, G.; Yang, D.; Chou, C.J.; Sole, J.; Nichols, A.; Ross, J.S.; Tartaglia, L.A.; et al. Chronic inflammation in fat plays a crucial role in the development of obesity-related insulin resistance. J. Clin. Investig. 2003, 112, 1821-1830. [CrossRef]

162. McLaughlin, T.; Ackerman, S.E.; Shen, L.; Engleman, E. Role of innate and adaptive immunity in obesity-associated metabolic disease. J. Clin. Investig. 2017, 127, 5-13. [CrossRef] [PubMed]

163. De la Monte, S.M.; Longato, L.; Tong, M.; Wands, J.R. Insulin resistance and neurodegeneration: Roles of obesity, type 2 diabetes mellitus and non-alcoholic steatohepatitis. Curr. Opin. Investig. Drugs 2009, 10, 1049-1060.

164. Procaccini, C.; Santopaolo, M.; Faicchia, D.; Colamatteo, A.; Formisano, L.; de Candia, P.; Galgani, M.; de Rosa, V.; Matarese, G. Role of metabolism in neurodegenerative disorders. Metabolism 2016, 65, 1376-1390. [CrossRef]

165. Balasubramanian, P.; Kiss, T.; Tarantini, S.; Nyul-Toth, A.; Ahire, C.; Yabluchanskiy, A.; Csipo, T.; Lipecz, A.; Tabak, A.; Institoris, A.; et al. Obesity-induced cognitive impairment in older adults: A microvascular perspective. Am. J. Physiol. Heart Circ. Physiol. 2021, 320, H740-H761. [CrossRef] [PubMed]

166. Milaneschi, Y.; Simmons, W.K.; van Rossum, E.F.C.; Penninx, B.W. Depression and obesity: Evidence of shared biological mechanisms. Mol. Psychiatry 2019, 24, 18-33. [CrossRef]

167. Anstey, K.J.; Cherbuin, N.; Budge, M.; Young, J. Body mass index in midlife and late-life as a risk factor for dementia: A meta-analysis of prospective studies. Obes. Rev. 2011, 12, e426-e437. [CrossRef]

168. Gudala, K.; Bansal, D.; Schifano, F.; Bhansali, A. Diabetes mellitus and risk of dementia: A meta-analysis of prospective observational studies. J. Diabetes Investig. 2013, 4, 640-650. [CrossRef]

169. Kanaya, A.M.; Lindquist, K.; Harris, T.B.; Launer, L.; Rosano, C.; Satterfield, S.; Yaffe, K.; Health, A.B.C.S. Total and regional adiposity and cognitive change in older adults: The Health, Aging and Body Composition (ABC) study. Arch. Neurol. 2009, 66, 329-335. [CrossRef]

170. Gunstad, J.; Lhotsky, A.; Wendell, C.R.; Ferrucci, L.; Zonderman, A.B. Longitudinal examination of obesity and cognitive function: Results from the Baltimore longitudinal study of aging. Neuroepidemiology 2010, 34, 222-229. [CrossRef]

171. Benito-Leon, J.; Mitchell, A.J.; Hernandez-Gallego, J.; Bermejo-Pareja, F. Obesity and impaired cognitive functioning in the elderly: A population-based cross-sectional study (NEDICES). Eur. J. Neurol. 2013, 20, 899-e77. [CrossRef] 
172. Munger, K.L.; Chitnis, T.; Ascherio, A. Body size and risk of MS in two cohorts of US women. Neurology 2009, 73, 1543-1550. [CrossRef] [PubMed]

173. Hedstrom, A.K.; Olsson, T.; Alfredsson, L. High body mass index before age 20 is associated with increased risk for multiple sclerosis in both men and women. Mult. Scler. 2012, 18, 1334-1336. [CrossRef] [PubMed]

174. Langer-Gould, A.; Brara, S.M.; Beaber, B.E.; Koebnick, C. Childhood obesity and risk of pediatric multiple sclerosis and clinically isolated syndrome. Neurology 2013, 80, 548-552. [CrossRef] [PubMed]

175. Mokry, L.E.; Ross, S.; Timpson, N.J.; Sawcer, S.; Davey Smith, G.; Richards, J.B. Obesity and multiple sclerosis: A mendelian randomization study. PLoS Med. 2016, 13, e1002053. [CrossRef]

176. Schachter, J.; Martel, J.; Lin, C.S.; Chang, C.J.; Wu, T.R.; Lu, C.C.; Ko, Y.F.; Lai, H.C.; Ojcius, D.M.; Young, J.D. Effects of obesity on depression: A role for inflammation and the gut microbiota. Brain Behav. Immun. 2018, 69, 1-8. [CrossRef] [PubMed]

177. Quek, Y.H.; Tam, W.W.S.; Zhang, M.W.B.; Ho, R.C.M. Exploring the association between childhood and adolescent obesity and depression: A meta-analysis. Obes. Rev. 2017, 18, 742-754. [CrossRef]

178. Jokela, M.; Hamer, M.; Singh-Manoux, A.; Batty, G.D.; Kivimaki, M. Association of metabolically healthy obesity with depressive symptoms: Pooled analysis of eight studies. Mol. Psychiatry 2014, 19, 910-914. [CrossRef]

179. Kullmann, S.; Schweizer, F.; Veit, R.; Fritsche, A.; Preissl, H. Compromised white matter integrity in obesity. Obes. Rev. 2015, 16, 273-281. [CrossRef]

180. Kullmann, S.; Heni, M.; Hallschmid, M.; Fritsche, A.; Preissl, H.; Haring, H.U. Brain insulin resistance at the crossroads of metabolic and cognitive disorders in humans. Physiol. Rev. 2016, 96, 1169-1209. [CrossRef] [PubMed]

181. Ward, M.A.; Carlsson, C.M.; Trivedi, M.A.; Sager, M.A.; Johnson, S.C. The effect of body mass index on global brain volume in middle-aged adults: A cross sectional study. BMC Neurol. 2005, 5, 23. [CrossRef]

182. Cazettes, F.; Cohen, J.I.; Yau, P.L.; Talbot, H.; Convit, A. Obesity-mediated inflammation may damage the brain circuit that regulates food intake. Brain Res. 2011, 1373, 101-109. [CrossRef] [PubMed]

183. Samara, A.; Murphy, T.; Strain, J.; Rutlin, J.; Sun, P.; Neyman, O.; Sreevalsan, N.; Shimony, J.S.; Ances, B.M.; Song, S.K.; et al. Neuroinflammation and white matter alterations in obesity assessed by diffusion basis spectrum imaging. Front. Hum. Neurosci. 2019, 13, 464. [CrossRef] [PubMed]

184. De Strooper, B.; Karran, E. The cellular phase of Alzheimer's disease. Cell 2016, 164, 603-615. [CrossRef]

185. Bartels, T.; de Schepper, S.; Hong, S. Microglia modulate neurodegeneration in Alzheimer's and Parkinson's diseases. Science 2020, 370, 66-69. [CrossRef] [PubMed]

186. Voet, S.; Prinz, M.; van Loo, G. Microglia in central nervous system inflammation and multiple sclerosis pathology. Trends Mol. Med. 2019, 25, 112-123. [CrossRef]

187. Troubat, R.; Barone, P.; Leman, S.; Desmidt, T.; Cressant, A.; Atanasova, B.; Brizard, B.; El Hage, W.; Surget, A.; Belzung, C.; et al. Neuroinflammation and depression: A review. Eur. J. Neurosci. 2021, 53, 151-171. [CrossRef]

188. Frohnert, B.I.; Jacobs, D.R., Jr.; Steinberger, J.; Moran, A.; Steffen, L.M.; Sinaiko, A.R. Relation between serum free fatty acids and adiposity, insulin resistance, and cardiovascular risk factors from adolescence to adulthood. Diabetes 2013, 62, 3163-3169. [CrossRef] [PubMed]

189. Levy, M.; Kolodziejczyk, A.A.; Thaiss, C.A.; Elinav, E. Dysbiosis and the immune system. Nat. Rev. Immunol. 2017, 17, 219-232. [CrossRef]

190. Erny, D.; Hrabe de Angelis, A.L.; Jaitin, D.; Wieghofer, P.; Staszewski, O.; David, E.; Keren-Shaul, H.; Mahlakoiv, T.; Jakobshagen, K.; Buch, T.; et al. Host microbiota constantly control maturation and function of microglia in the CNS. Nat. Neurosci. 2015, 18, 965-977. [CrossRef] [PubMed]

191. Swierczynska, M.M.; Mateska, I.; Peitzsch, M.; Bornstein, S.R.; Chavakis, T.; Eisenhofer, G.; Lamounier-Zepter, V.; Eaton, S. Changes in morphology and function of adrenal cortex in mice fed a high-fat diet. Int. J. Obes. 2015, 39, 321-330. [CrossRef] [PubMed]

192. Sorrells, S.F.; Caso, J.R.; Munhoz, C.D.; Sapolsky, R.M. The stressed CNS: When glucocorticoids aggravate inflammation. Neuron 2009, 64, 33-39. [CrossRef] [PubMed]

193. Sorrells, S.F.; Munhoz, C.D.; Manley, N.C.; Yen, S.; Sapolsky, R.M. Glucocorticoids increase excitotoxic injury and inflammation in the hippocampus of adult male rats. Neuroendocrinology 2014, 100, 129-140. [CrossRef] [PubMed]

194. Hao, S.; Dey, A.; Yu, X.; Stranahan, A.M. Dietary obesity reversibly induces synaptic stripping by microglia and impairs hippocampal plasticity. Brain Behav. Immun. 2016, 51, 230-239. [CrossRef] [PubMed]

195. Cope, E.C.; LaMarca, E.A.; Monari, P.K.; Olson, L.B.; Martinez, S.; Zych, A.D.; Katchur, N.J.; Gould, E. Microglia play an active role in obesity-associated cognitive decline. J. Neurosci. 2018, 38, 8889-8904. [CrossRef] [PubMed]

196. Butler, M.J.; Cole, R.M.; Deems, N.P.; Belury, M.A.; Barrientos, R.M. Fatty food, fatty acids, and microglial priming in the adult and aged hippocampus and amygdala. Brain Behav. Immun. 2020, 89, 145-158. [CrossRef]

197. Kawamura, N.; Katsuura, G.; Yamada-Goto, N.; Novianti, E.; Inui, A.; Asakawa, A. Impaired brain fractalkine-CX3CR1 signaling is implicated in cognitive dysfunction in diet-induced obese mice. BMJ Open Diabetes Res. Care 2021, 9, 1. [CrossRef]

198. Cai, M.; Wang, H.; Li, J.J.; Zhang, Y.L.; Xin, L.; Li, F.; Lou, S.J. The signaling mechanisms of hippocampal endoplasmic reticulum stress affecting neuronal plasticity-related protein levels in high fat diet-induced obese rats and the regulation of aerobic exercise. Brain Behav. Immun. 2016, 57, 347-359. [CrossRef] [PubMed] 
199. Nakandakari, S.; Munoz, V.R.; Kuga, G.K.; Gaspar, R.C.; Sant'Ana, M.R.; Pavan, I.C.B.; da Silva, L.G.S.; Morelli, A.P.; Simabuco, F.M.; da Silva, A.S.R.; et al. Short-term high-fat diet modulates several inflammatory, ER stress, and apoptosis markers in the hippocampus of young mice. Brain Behav. Immun. 2019, 79, 284-293. [CrossRef]

200. Scheiblich, H.; Schlutter, A.; Golenbock, D.T.; Latz, E.; Martinez-Martinez, P.; Heneka, M.T. Activation of the NLRP3 inflammasome in microglia: The role of ceramide. J. Neurochem. 2017, 143, 534-550. [CrossRef] [PubMed]

201. Feng, X.; Zhao, Y.; Yang, T.; Song, M.; Wang, C.; Yao, Y.; Fan, H. Glucocorticoid-driven NLRP3 inflammasome activation in hippocampal microglia mediates chronic stress-induced depressive-like behaviors. Front. Mol. Neurosci. 2019, 12, 210. [CrossRef]

202. Jeon, B.T.; Jeong, E.A.; Shin, H.J.; Lee, Y.; Lee, D.H.; Kim, H.J.; Kang, S.S.; Cho, G.J.; Choi, W.S.; Roh, G.S. Resveratrol attenuates obesity-associated peripheral and central inflammation and improves memory deficit in mice fed a high-fat diet. Diabetes 2012, 61, 1444-1454. [CrossRef] [PubMed]

203. Sims-Robinson, C.; Bakeman, A.; Glasser, R.; Boggs, J.; Pacut, C.; Feldman, E.L. The role of endoplasmic reticulum stress in hippocampal insulin resistance. Exp. Neurol. 2016, 277, 261-267. [CrossRef]

204. Stranahan, A.M.; Norman, E.D.; Lee, K.; Cutler, R.G.; Telljohann, R.S.; Egan, J.M.; Mattson, M.P. Diet-induced insulin resistance impairs hippocampal synaptic plasticity and cognition in middle-aged rats. Hippocampus 2008, 18, 1085-1088. [CrossRef] [PubMed]

205. Kroner, A.; Greenhalgh, A.D.; Zarruk, J.G.; Passos Dos Santos, R.; Gaestel, M.; David, S. TNF and increased intracellular iron alter macrophage polarization to a detrimental M1 phenotype in the injured spinal cord. Neuron 2014, 83, 1098-1116. [CrossRef] [PubMed]

206. Siddiqui, T.A.; Lively, S.; Schlichter, L.C. Complex molecular and functional outcomes of single versus sequential cytokine stimulation of rat microglia. J. Neuroinflamm. 2016, 13, 66. [CrossRef] [PubMed]

207. Gao, Y.; Vidal-Itriago, A.; Milanova, I.; Korpel, N.L.; Kalsbeek, M.J.; Tom, R.Z.; Kalsbeek, A.; Hofmann, S.M.; Yi, C.X. Deficiency of leptin receptor in myeloid cells disrupts hypothalamic metabolic circuits and causes body weight increase. Mol. Metab. 2018, 7, 155-160. [CrossRef] [PubMed]

208. Tang, C.H.; Lu, D.Y.; Yang, R.S.; Tsai, H.Y.; Kao, M.C.; Fu, W.M.; Chen, Y.F. Leptin-induced IL-6 production is mediated by leptin receptor, insulin receptor substrate-1, phosphatidylinositol 3-kinase, Akt, NF-kappaB, and p300 pathway in microglia. J. Immunol. 2007, 179, 1292-1302. [CrossRef]

209. Lafrance, V.; Inoue, W.; Kan, B.; Luheshi, G.N. Leptin modulates cell morphology and cytokine release in microglia. Brain Behav. Immun. 2010, 24, 358-365. [CrossRef] [PubMed]

210. Fernandez-Martos, C.M.; Gonzalez, P.; Rodriguez, F.J. Acute leptin treatment enhances functional recovery after spinal cord injury. PLoS ONE 2012, 7, e35594. [CrossRef]

211. Vinuesa, A.; Bentivegna, M.; Calfa, G.; Filipello, F.; Pomilio, C.; Bonaventura, M.M.; Lux-Lantos, V.; Matzkin, M.E.; Gregosa, A.; Presa, J.; et al. Early exposure to a high-fat diet impacts on hippocampal plasticity: Implication of microglia-derived exosome-like extracellular vesicles. Mol. Neurobiol. 2019, 56, 5075-5094. [CrossRef] [PubMed]

212. Milanski, M.; Degasperi, G.; Coope, A.; Morari, J.; Denis, R.; Cintra, D.E.; Tsukumo, D.M.; Anhe, G.; Amaral, M.E.; Takahashi, H.K.; et al. Saturated fatty acids produce an inflammatory response predominantly through the activation of TLR4 signaling in hypothalamus: Implications for the pathogenesis of obesity. J. Neurosci. 2009, 29, 359-370. [CrossRef]

213. Yanguas-Casas, N.; Crespo-Castrillo, A.; de Ceballos, M.L.; Chowen, J.A.; Azcoitia, I.; Arevalo, M.A.; Garcia-Segura, L.M. Sex differences in the phagocytic and migratory activity of microglia and their impairment by palmitic acid. Glia 2018, 66, 522-537. [CrossRef] [PubMed]

214. Wang, Z.; Liu, D.; Wang, F.; Liu, S.; Zhao, S.; Ling, E.A.; Hao, A. Saturated fatty acids activate microglia via Toll-like receptor 4/NF-kappaB signalling. Br. J. Nutr. 2012, 107, 229-241. [CrossRef]

215. Bazinet, R.P.; Laye, S. Polyunsaturated fatty acids and their metabolites in brain function and disease. Nat. Rev. Neurosci. 2014, 15, 771-785. [CrossRef] [PubMed]

216. Laye, S.; Nadjar, A.; Joffre, C.; Bazinet, R.P. Anti-inflammatory effects of omega-3 fatty acids in the brain: Physiological mechanisms and relevance to pharmacology. Pharmacol. Rev. 2018, 70, 12-38. [CrossRef]

217. Oksman, M.; Iivonen, H.; Hogyes, E.; Amtul, Z.; Penke, B.; Leenders, I.; Broersen, L.; Lutjohann, D.; Hartmann, T.; Tanila, H. Impact of different saturated fatty acid, polyunsaturated fatty acid and cholesterol containing diets on beta-amyloid accumulation in APP/PS1 transgenic mice. Neurobiol. Dis. 2006, 23, 563-572. [CrossRef] [PubMed]

218. Ma, Q.L.; Yang, F.; Rosario, E.R.; Ubeda, O.J.; Beech, W.; Gant, D.J.; Chen, P.P.; Hudspeth, B.; Chen, C.; Zhao, Y.; et al. Beta-amyloid oligomers induce phosphorylation of tau and inactivation of insulin receptor substrate via c-Jun N-terminal kinase signaling: Suppression by omega-3 fatty acids and curcumin. J. Neurosci. 2009, 29, 9078-9089. [CrossRef]

219. De Smedt-Peyrusse, V.; Sargueil, F.; Moranis, A.; Harizi, H.; Mongrand, S.; Laye, S. Docosahexaenoic acid prevents lipopolysaccharide-induced cytokine production in microglial cells by inhibiting lipopolysaccharide receptor presentation but not its membrane subdomain localization. J. Neurochem. 2008, 105, 296-307. [CrossRef] [PubMed]

220. Antonietta Ajmone-Cat, M.; Lavinia Salvatori, M.; de Simone, R.; Mancini, M.; Biagioni, S.; Bernardo, A.; Cacci, E.; Minghetti, L. Docosahexaenoic acid modulates inflammatory and antineurogenic functions of activated microglial cells. J. Neurosci. Res. 2012, 90, 575-587. [CrossRef]

221. Mulders, R.J.; de Git, K.C.G.; Schele, E.; Dickson, S.L.; Sanz, Y.; Adan, R.A.H. Microbiota in obesity: Interactions with enteroendocrine, immune and central nervous systems. Obes. Rev. 2018, 19, 435-451. [CrossRef] 
222. Soto, M.; Herzog, C.; Pacheco, J.A.; Fujisaka, S.; Bullock, K.; Clish, C.B.; Kahn, C.R. Gut microbiota modulate neurobehavior through changes in brain insulin sensitivity and metabolism. Mol. Psychiatry 2018, 23, 2287-2301. [CrossRef] [PubMed]

223. Sampson, T.R.; Debelius, J.W.; Thron, T.; Janssen, S.; Shastri, G.G.; Ilhan, Z.E.; Challis, C.; Schretter, C.E.; Rocha, S.; Gradinaru, V.; et al. Gut microbiota regulate motor deficits and neuroinflammation in a model of Parkinson's disease. Cell 2016, 167, 1469-1480.e12. [CrossRef]

224. Witt, A.; Mirtschink, P.; Palladini, A.; Mateska, I.; Abdelmegeed, H.; Grzybek, M.; Wielockx, B.; Peitzsch, M.; Coskun, Ü.; Chavakis, T.; et al. Obesity-associated lipidomic remodeling of the adrenal gland indicates an important role of the FADS2-arachidonic acid axis in adrenocortical hormone production. bioRxiv 2020. [CrossRef]

225. Stranahan, A.M.; Arumugam, T.V.; Cutler, R.G.; Lee, K.; Egan, J.M.; Mattson, M.P. Diabetes impairs hippocampal function through glucocorticoid-mediated effects on new and mature neurons. Nat. Neurosci. 2008, 11, 309-317. [CrossRef]

226. Hofmann, A.; Peitzsch, M.; Brunssen, C.; Mittag, J.; Jannasch, A.; Frenzel, A.; Brown, N.; Weldon, S.M.; Eisenhofer, G.; Bornstein, S.R.; et al. Elevated steroid hormone production in the $\mathrm{db} / \mathrm{db}$ mouse model of obesity and type 2 diabetes. Horm. Metab. Res. 2017, 49, 43-49. [CrossRef]

227. Sobesky, J.L.; D'Angelo, H.M.; Weber, M.D.; Anderson, N.D.; Frank, M.G.; Watkins, L.R.; Maier, S.F.; Barrientos, R.M. Glucocorticoids mediate short-term high-fat diet induction of neuroinflammatory priming, the NLRP3 inflammasome, and the danger signal HMGB1. eNeuro 2016, 3. [CrossRef]

228. Van Olst, L.; Bielefeld, P.; Fitzsimons, C.P.; de Vries, H.E.; Schouten, M. Glucocorticoid-mediated modulation of morphological changes associated with aging in microglia. Aging Cell 2018, 17, e12790. [CrossRef] [PubMed]

229. Ros-Bernal, F.; Hunot, S.; Herrero, M.T.; Parnadeau, S.; Corvol, J.C.; Lu, L.; Alvarez-Fischer, D.; Carrillo-de Sauvage, M.A.; Saurini, F.; Coussieu, C.; et al. Microglial glucocorticoid receptors play a pivotal role in regulating dopaminergic neurodegeneration in parkinsonism. Proc. Natl. Acad. Sci. USA 2011, 108, 6632-6637. [CrossRef]

230. Maatouk, L.; Compagnion, A.C.; Sauvage, M.C.; Bemelmans, A.P.; Leclere-Turbant, S.; Cirotteau, V.; Tohme, M.; Beke, A.; Trichet, M.; Bazin, V.; et al. TLR9 activation via microglial glucocorticoid receptors contributes to degeneration of midbrain dopamine neurons. Nat. Commun. 2018, 9, 2450. [CrossRef] [PubMed]

231. Valladolid-Acebes, I.; Fole, A.; Martin, M.; Morales, L.; Cano, M.V.; Ruiz-Gayo, M.; Del Olmo, N. Spatial memory impairment and changes in hippocampal morphology are triggered by high-fat diets in adolescent mice. Is there a role of leptin? Neurobiol. Learn. Mem. 2013, 106, 18-25. [CrossRef] [PubMed]

232. Heyward, F.D.; Walton, R.G.; Carle, M.S.; Coleman, M.A.; Garvey, W.T.; Sweatt, J.D. Adult mice maintained on a high-fat diet exhibit object location memory deficits and reduced hippocampal SIRT1 gene expression. Neurobiol. Learn. Mem. 2012, 98, 25-32. [CrossRef]

233. Hwang, L.L.; Wang, C.H.; Li, T.L.; Chang, S.D.; Lin, L.C.; Chen, C.P.; Chen, C.T.; Liang, K.C.; Ho, I.K.; Yang, W.S.; et al. Sex differences in high-fat diet-induced obesity, metabolic alterations and learning, and synaptic plasticity deficits in mice. Obesity 2010, 18, 463-469. [CrossRef] [PubMed]

234. Woo, J.; Shin, K.O.; Park, S.Y.; Jang, K.S.; Kang, S. Effects of exercise and diet change on cognition function and synaptic plasticity in high fat diet induced obese rats. Lipids Health Dis. 2013, 12, 144. [CrossRef] [PubMed]

235. Granholm, A.C.; Bimonte-Nelson, H.A.; Moore, A.B.; Nelson, M.E.; Freeman, L.R.; Sambamurti, K. Effects of a saturated fat and high cholesterol diet on memory and hippocampal morphology in the middle-aged rat. J. Alzheimers Dis. 2008, 14, 133-145. [CrossRef]

236. Erion, J.R.; Wosiski-Kuhn, M.; Dey, A.; Hao, S.; Davis, C.L.; Pollock, N.K.; Stranahan, A.M. Obesity elicits interleukin 1-mediated deficits in hippocampal synaptic plasticity. J. Neurosci. 2014, 34, 2618-2631. [CrossRef]

237. Bocarsly, M.E.; Fasolino, M.; Kane, G.A.; LaMarca, E.A.; Kirschen, G.W.; Karatsoreos, I.N.; McEwen, B.S.; Gould, E. Obesity diminishes synaptic markers, alters microglial morphology, and impairs cognitive function. Proc. Natl. Acad. Sci. USA 2015, 112, 15731-15736. [CrossRef] [PubMed]

238. Shinohara, M.; Tashiro, Y.; Shinohara, M.; Hirokawa, J.; Suzuki, K.; Onishi-Takeya, M.; Mukouzono, M.; Takeda, S.; Saito, T.; Fukumori, A.; et al. Increased levels of Abeta42 decrease the lifespan of ob/ob mice with dysregulation of microglia and astrocytes. FASEB J. 2020, 34, 2425-2435. [CrossRef]

239. Sobesky, J.L.; Barrientos, R.M.; de May, H.S.; Thompson, B.M.; Weber, M.D.; Watkins, L.R.; Maier, S.F. High-fat diet consumption disrupts memory and primes elevations in hippocampal IL-1beta, an effect that can be prevented with dietary reversal or IL-1 receptor antagonism. Brain Behav. Immun. 2014, 42, 22-32. [CrossRef]

240. Brykczynska, U.; Geigges, M.; Wiedemann, S.J.; Dror, E.; Boni-Schnetzler, M.; Hess, C.; Donath, M.Y.; Paro, R. Distinct transcriptional responses across tissue-resident macrophages to short-term and long-term metabolic challenge. Cell Rep. 2020, 30, 1627-1643.e7. [CrossRef]

241. Dror, E.; Dalmas, E.; Meier, D.T.; Wueest, S.; Thevenet, J.; Thienel, C.; Timper, K.; Nordmann, T.M.; Traub, S.; Schulze, F.; et al. Postprandial macrophage-derived IL-1beta stimulates insulin, and both synergistically promote glucose disposal and inflammation. Nat. Immunol. 2017, 18, 283-292. [CrossRef]

242. Cavaliere, G.; Trinchese, G.; Penna, E.; Cimmino, F.; Pirozzi, C.; Lama, A.; Annunziata, C.; Catapano, A.; Mattace Raso, G.; Meli, R.; et al. High-fat diet induces neuroinflammation and mitochondrial impairment in mice cerebral cortex and synaptic fraction. Front. Cell Neurosci. 2019, 13, 509. [CrossRef] [PubMed] 
243. Cai, M.; Hu, J.Y.; Liu, B.B.; Li, J.J.; Li, F.; Lou, S. The molecular mechanisms of excessive hippocampal endoplasmic reticulum stress depressing cognition-related proteins expression and the regulatory effects of Nrf2. Neuroscience 2020, 431, 152-165. [CrossRef] [PubMed]

244. Tucsek, Z.; Toth, P.; Sosnowska, D.; Gautam, T.; Mitschelen, M.; Koller, A.; Szalai, G.; Sonntag, W.E.; Ungvari, Z.; Csiszar, A. Obesity in aging exacerbates blood-brain barrier disruption, neuroinflammation, and oxidative stress in the mouse hippocampus: Effects on expression of genes involved in beta-amyloid generation and Alzheimer's disease. J. Gerontol. A Biol. Sci. Med. Sci. 2014, 69, 1212-1226. [CrossRef] [PubMed]

245. Graham, L.C.; Harder, J.M.; Soto, I.; de Vries, W.N.; John, S.W.; Howell, G.R. Chronic consumption of a western diet induces robust glial activation in aging mice and in a mouse model of Alzheimer's disease. Sci. Rep. 2016, 6, 21568. [CrossRef] [PubMed]

246. Valcarcel-Ares, M.N.; Tucsek, Z.; Kiss, T.; Giles, C.B.; Tarantini, S.; Yabluchanskiy, A.; Balasubramanian, P.; Gautam, T.; Galvan, V.; Ballabh, P.; et al. Obesity in aging exacerbates neuroinflammation, dysregulating synaptic function-related genes and altering eicosanoid synthesis in the mouse hippocampus: Potential role in impaired synaptic plasticity and cognitive decline. J. Gerontol. A Biol. Sci. Med. Sci. 2019, 74, 290-298. [CrossRef] [PubMed]

247. Yin, Z.; Raj, D.D.; Schaafsma, W.; van der Heijden, R.A.; Kooistra, S.M.; Reijne, A.C.; Zhang, X.; Moser, J.; Brouwer, N.; Heeringa, P.; et al. Low-fat diet with caloric restriction reduces white matter microglia activation during aging. Front. Mol. Neurosci. 2018, 11, 65. [CrossRef] [PubMed]

248. Julien, C.; Tremblay, C.; Phivilay, A.; Berthiaume, L.; Emond, V.; Julien, P.; Calon, F. High-fat diet aggravates amyloid-beta and tau pathologies in the 3xTg-AD mouse model. Neurobiol. Aging 2010, 31, 1516-1531. [CrossRef] [PubMed]

249. Leboucher, A.; Laurent, C.; Fernandez-Gomez, F.J.; Burnouf, S.; Troquier, L.; Eddarkaoui, S.; Demeyer, D.; Caillierez, R.; Zommer, N.; Vallez, E.; et al. Detrimental effects of diet-induced obesity on tau pathology are independent of insulin resistance in tau transgenic mice. Diabetes 2013, 62, 1681-1688. [CrossRef] [PubMed]

250. Maesako, M.; Uemura, K.; Kubota, M.; Kuzuya, A.; Sasaki, K.; Hayashida, N.; Asada-Utsugi, M.; Watanabe, K.; Uemura, M.; Kihara, T.; et al. Exercise is more effective than diet control in preventing high fat diet-induced beta-amyloid deposition and memory deficit in amyloid precursor protein transgenic mice. J. Biol. Chem. 2012, 287, 23024-23033. [CrossRef] [PubMed]

251. Ivanova, N.; Liu, Q.; Agca, C.; Agca, Y.; Noble, E.G.; Whitehead, S.N.; Cechetto, D.F. White matter inflammation and cognitive function in a co-morbid metabolic syndrome and prodromal Alzheimer's disease rat model. J. Neuroinflamm. 2020, 17, 29. [CrossRef]

252. Choi, J.Y.; Jang, E.H.; Park, C.S.; Kang, J.H. Enhanced susceptibility to 1-methyl-4-phenyl-1,2,3,6-tetrahydropyridine neurotoxicity in high-fat diet-induced obesity. Free Radic. Biol. Med. 2005, 38, 806-816. [CrossRef] [PubMed]

253. Morris, J.K.; Bomhoff, G.L.; Stanford, J.A.; Geiger, P.C. Neurodegeneration in an animal model of Parkinson's disease is exacerbated by a high-fat diet. Am. J. Physiol. Regul. Integr. Comp. Physiol. 2010, 299, R1082-R1090. [CrossRef] [PubMed]

254. Boitard, C.; Cavaroc, A.; Sauvant, J.; Aubert, A.; Castanon, N.; Laye, S.; Ferreira, G. Impairment of hippocampal-dependent memory induced by juvenile high-fat diet intake is associated with enhanced hippocampal inflammation in rats. Brain Behav. Immun. 2014, 40, 9-17. [CrossRef]

255. Andre, C.; Dinel, A.L.; Ferreira, G.; Laye, S.; Castanon, N. Diet-induced obesity progressively alters cognition, anxiety-like behavior and lipopolysaccharide-induced depressive-like behavior: Focus on brain indoleamine 2,3-dioxygenase activation. Brain Behav. Immun. 2014, 41, 10-21. [CrossRef]

256. Gao, Y.; Ottaway, N.; Schriever, S.C.; Legutko, B.; Garcia-Caceres, C.; de la Fuente, E.; Mergen, C.; Bour, S.; Thaler, J.P.; Seeley, R.J.; et al. Hormones and diet, but not body weight, control hypothalamic microglial activity. Glia 2014, 62, 17-25. [CrossRef]

257. Thaler, J.P.; Yi, C.X.; Schur, E.A.; Guyenet, S.J.; Hwang, B.H.; Dietrich, M.O.; Zhao, X.; Sarruf, D.A.; Izgur, V.; Maravilla, K.R.; et al. Obesity is associated with hypothalamic injury in rodents and humans. J. Clin. Investig. 2012, 122, 153-162. [CrossRef]

258. Baufeld, C.; Osterloh, A.; Prokop, S.; Miller, K.R.; Heppner, F.L. High-fat diet-induced brain region-specific phenotypic spectrum of CNS resident microglia. Acta Neuropathol. 2016, 132, 361-375. [CrossRef] [PubMed]

259. Zhang, X.; Zhang, G.; Zhang, H.; Karin, M.; Bai, H.; Cai, D. Hypothalamic IKKbeta/NF-kappaB and ER stress link overnutrition to energy imbalance and obesity. Cell 2008, 135, 61-73. [CrossRef]

260. Horvath, T.L.; Sarman, B.; Garcia-Caceres, C.; Enriori, P.J.; Sotonyi, P.; Shanabrough, M.; Borok, E.; Argente, J.; Chowen, J.A.; Perez-Tilve, D.; et al. Synaptic input organization of the melanocortin system predicts diet-induced hypothalamic reactive gliosis and obesity. Proc. Natl. Acad. Sci. USA 2010, 107, 14875-14880. [CrossRef]

261. Butler, M.J.; Perrini, A.A.; Eckel, L.A. Estradiol treatment attenuates high fat diet-induced microgliosis in ovariectomized rats. Horm. Behav. 2020, 120, 104675. [CrossRef]

262. De Souza, C.T.; Araujo, E.P.; Bordin, S.; Ashimine, R.; Zollner, R.L.; Boschero, A.C.; Saad, M.J.; Velloso, L.A. Consumption of a fat-rich diet activates a proinflammatory response and induces insulin resistance in the hypothalamus. Endocrinology 2005, 146, 4192-4199. [CrossRef] [PubMed]

263. Posey, K.A.; Clegg, D.J.; Printz, R.L.; Byun, J.; Morton, G.J.; Vivekanandan-Giri, A.; Pennathur, S.; Baskin, D.G.; Heinecke, J.W.; Woods, S.C.; et al. Hypothalamic proinflammatory lipid accumulation, inflammation, and insulin resistance in rats fed a high-fat diet. Am. J. Physiol. Endocrinol. Metab. 2009, 296, E1003-E1012. [CrossRef] [PubMed]

264. Cavaliere, G.; Viggiano, E.; Trinchese, G.; de Filippo, C.; Messina, A.; Monda, V.; Valenzano, A.; Cincione, R.I.; Zammit, C.; Cimmino, F.; et al. Long feeding high-fat diet induces hypothalamic oxidative stress and inflammation, and prolonged hypothalamic AMPK activation in rat animal model. Front. Physiol. 2018, 9, 818. [CrossRef] [PubMed] 
265. Ozcan, L.; Ergin, A.S.; Lu, A.; Chung, J.; Sarkar, S.; Nie, D.; Myers, M.G., Jr.; Ozcan, U. Endoplasmic reticulum stress plays a central role in development of leptin resistance. Cell Metab. 2009, 9, 35-51. [CrossRef]

266. Weissmann, L.; Quaresma, P.G.; Santos, A.C.; de Matos, A.H.; Pascoal, V.D.; Zanotto, T.M.; Castro, G.; Guadagnini, D.; da Silva, J.M.; Velloso, L.A.; et al. IKKepsilon is key to induction of insulin resistance in the hypothalamus, and its inhibition reverses obesity. Diabetes 2014, 63, 3334-3345. [CrossRef] [PubMed]

267. Andre, C.; Guzman-Quevedo, O.; Rey, C.; Remus-Borel, J.; Clark, S.; Castellanos-Jankiewicz, A.; Ladeveze, E.; Leste-Lasserre, T.; Nadjar, A.; Abrous, D.N.; et al. Inhibiting microglia expansion prevents diet-induced hypothalamic and peripheral inflammation. Diabetes 2017, 66, 908-919. [CrossRef] [PubMed]

268. Valdearcos, M.; Robblee, M.M.; Benjamin, D.I.; Nomura, D.K.; Xu, A.W.; Koliwad, S.K. Microglia dictate the impact of saturated fat consumption on hypothalamic inflammation and neuronal function. Cell Rep. 2014, 9, 2124-2138. [CrossRef]

269. Valdearcos, M.; Douglass, J.D.; Robblee, M.M.; Dorfman, M.D.; Stifler, D.R.; Bennett, M.L.; Gerritse, I.; Fasnacht, R.; Barres, B.A.; Thaler, J.P.; et al. Microglial inflammatory signaling orchestrates the hypothalamic immune response to dietary excess and mediates obesity susceptibility. Cell Metab. 2017, 26, 185-197.e3. [CrossRef] [PubMed]

270. Li, J.; Tang, Y.; Cai, D. IKKbeta/NF-kappaB disrupts adult hypothalamic neural stem cells to mediate a neurodegenerative mechanism of dietary obesity and pre-diabetes. Nat. Cell Biol. 2012, 14, 999-1012. [CrossRef]

271. McNay, D.E.; Briancon, N.; Kokoeva, M.V.; Maratos-Flier, E.; Flier, J.S. Remodeling of the arcuate nucleus energy-balance circuit is inhibited in obese mice. J. Clin. Investig. 2012, 122, 142-152. [CrossRef]

272. Jais, A.; Bruning, J.C. Hypothalamic inflammation in obesity and metabolic disease. J. Clin. Investig. 2017, 127, 24-32. [CrossRef]

273. Dionysopoulou, S.; Charmandari, E.; Bargiota, A.; Vlahos, N.; Mastorakos, G.; Valsamakis, G. The role of hypothalamic inflammation in diet-induced obesity and its association with cognitive and mood disorders. Nutrients 2021, 13, 498. [CrossRef]

274. Dorfman, M.D.; Thaler, J.P. Hypothalamic inflammation and gliosis in obesity. Curr. Opin. Endocrinol. Diabetes Obes. 2015, 22, 325-330. [CrossRef]

275. Schur, E.A.; Melhorn, S.J.; Oh, S.K.; Lacy, J.M.; Berkseth, K.E.; Guyenet, S.J.; Sonnen, J.A.; Tyagi, V.; Rosalynn, M.; de Leon, B.; et al. Radiologic evidence that hypothalamic gliosis is associated with obesity and insulin resistance in humans. Obesity 2015, 23, 2142-2148. [CrossRef]

276. Puig, J.; Blasco, G.; Daunis, I.E.J.; Molina, X.; Xifra, G.; Ricart, W.; Pedraza, S.; Fernandez-Aranda, F.; Fernandez-Real, J.M. Hypothalamic damage is associated with inflammatory markers and worse cognitive performance in obese subjects. J. Clin. Endocrinol. Metab. 2015, 100, E276-E281. [CrossRef] [PubMed]

277. Contreras, C.; Gonzalez-Garcia, I.; Martinez-Sanchez, N.; Seoane-Collazo, P.; Jacas, J.; Morgan, D.A.; Serra, D.; Gallego, R.; Gonzalez, F.; Casals, N.; et al. Central ceramide-induced hypothalamic lipotoxicity and ER stress regulate energy balance. Cell Rep. 2014, 9, 366-377. [CrossRef]

278. Kleinridders, A.; Schenten, D.; Konner, A.C.; Belgardt, B.F.; Mauer, J.; Okamura, T.; Wunderlich, F.T.; Medzhitov, R.; Bruning, J.C. MyD88 signaling in the CNS is required for development of fatty acid-induced leptin resistance and diet-induced obesity. Cell Metab. 2009, 10, 249-259. [CrossRef] [PubMed]

279. Yang, H.; Graham, L.C.; Reagan, A.M.; Grabowska, W.A.; Schott, W.H.; Howell, G.R. Transcriptome profiling of brain myeloid cells revealed activation of Itgal, Trem1, and Spp1 in western diet-induced obesity. J. Neuroinflamm. 2019, 16, 169. [CrossRef] [PubMed]

280. Shigemoto-Mogami, Y.; Hoshikawa, K.; Sato, K. Activated Microglia disrupt the blood-brain barrier and induce chemokines and cytokines in a rat in vitro model. Front. Cell Neurosci. 2018, 12, 494. [CrossRef] [PubMed]

281. Bar-Or, A.; Nuttall, R.K.; Duddy, M.; Alter, A.; Kim, H.J.; Ifergan, I.; Pennington, C.J.; Bourgoin, P.; Edwards, D.R.; Yong, V.W. Analyses of all matrix metalloproteinase members in leukocytes emphasize monocytes as major inflammatory mediators in multiple sclerosis. Brain 2003, 126 Pt 12, 2738-2749. [CrossRef]

282. Muri, L.; Leppert, D.; Grandgirard, D.; Leib, S.L. MMPs and ADAMs in neurological infectious diseases and multiple sclerosis. Cell. Mol. Life Sci. 2019, 76, 3097-3116. [CrossRef] [PubMed]

283. Amaya, J.M.; Suidgeest, E.; Sahut-Barnola, I.; Dumontet, T.; Montanier, N.; Pages, G.; Keller, C.; van der Weerd, L.; Pereira, A.M.; Martinez, A.; et al. Effects of long-term endogenous corticosteroid exposure on brain volume and glial cells in the AdKO mouse. Front. Neurosci. 2021, 15, 604103. [CrossRef] [PubMed]

284. Van der Werff, S.J.; Andela, C.D.; Nienke Pannekoek, J.; Meijer, O.C.; van Buchem, M.A.; Rombouts, S.A.; van der Mast, R.C.; Biermasz, N.R.; Pereira, A.M.; van der Wee, N.J. Widespread reductions of white matter integrity in patients with long-term remission of Cushing's disease. Neuroimage Clin. 2014, 4, 659-667. [CrossRef]

285. Tucsek, Z.; Toth, P.; Tarantini, S.; Sosnowska, D.; Gautam, T.; Warrington, J.P.; Giles, C.B.; Wren, J.D.; Koller, A.; Ballabh, P.; et al. Aging exacerbates obesity-induced cerebromicrovascular rarefaction, neurovascular uncoupling, and cognitive decline in mice. $J$. Gerontol. A Biol. Sci. Med. Sci. 2014, 69, 1339-1352. [CrossRef] [PubMed]

286. Profaci, C.P.; Munji, R.N.; Pulido, R.S.; Daneman, R. The blood-brain barrier in health and disease: Important unanswered questions. J. Exp. Med. 2020, 217, e20190062. [CrossRef] [PubMed]

287. Jolivel, V.; Bicker, F.; Biname, F.; Ploen, R.; Keller, S.; Gollan, R.; Jurek, B.; Birkenstock, J.; Poisa-Beiro, L.; Bruttger, J.; et al. Perivascular microglia promote blood vessel disintegration in the ischemic penumbra. Acta Neuropathol. 2015, 129, 279-295. [CrossRef] 
288. Haruwaka, K.; Ikegami, A.; Tachibana, Y.; Ohno, N.; Konishi, H.; Hashimoto, A.; Matsumoto, M.; Kato, D.; Ono, R.; Kiyama, H.; et al. Dual microglia effects on blood brain barrier permeability induced by systemic inflammation. Nat. Commun. 2019, 10,5816 . [CrossRef]

289. Sumi, N.; Nishioku, T.; Takata, F.; Matsumoto, J.; Watanabe, T.; Shuto, H.; Yamauchi, A.; Dohgu, S.; Kataoka, Y. Lipopolysaccharideactivated microglia induce dysfunction of the blood-brain barrier in rat microvascular endothelial cells co-cultured with microglia. Cell Mol. Neurobiol. 2010, 30, 247-253. [CrossRef] [PubMed]

290. Kanoski, S.E.; Zhang, Y.; Zheng, W.; Davidson, T.L. The effects of a high-energy diet on hippocampal function and blood-brain barrier integrity in the rat. J. Alzheimers Dis. 2010, 21, 207-219. [CrossRef] [PubMed]

291. Davidson, T.L.; Monnot, A.; Neal, A.U.; Martin, A.A.; Horton, J.J.; Zheng, W. The effects of a high-energy diet on hippocampaldependent discrimination performance and blood-brain barrier integrity differ for diet-induced obese and diet-resistant rats. Physiol. Behav. 2012, 107, 26-33. [CrossRef] [PubMed]

292. Acharya, N.K.; Levin, E.C.; Clifford, P.M.; Han, M.; Tourtellotte, R.; Chamberlain, D.; Pollaro, M.; Coretti, N.J.; Kosciuk, M.C.; Nagele, E.P.; et al. Diabetes and hypercholesterolemia increase blood-brain barrier permeability and brain amyloid deposition: Beneficial effects of the LpPLA2 inhibitor darapladib. J. Alzheimers Dis. 2013, 35, 179-198. [CrossRef]

293. Hargrave, S.L.; Davidson, T.L.; Zheng, W.; Kinzig, K.P. Western diets induce blood-brain barrier leakage and alter spatial strategies in rats. Behav. Neurosci. 2016, 130, 123-135. [CrossRef] [PubMed]

294. Fuller, J.P.; Stavenhagen, J.B.; Teeling, J.L. New roles for Fc receptors in neurodegeneration-the impact on Immunotherapy for Alzheimer's disease. Front. Neurosci. 2014, 8, 235. [CrossRef]

295. Davalos, D.; Ryu, J.K.; Merlini, M.; Baeten, K.M.; Le Moan, N.; Petersen, M.A.; Deerinck, T.J.; Smirnoff, D.S.; Bedard, C.; Hakozaki, H.; et al. Fibrinogen-induced perivascular microglial clustering is required for the development of axonal damage in neuroinflammation. Nat. Commun. 2012, 3, 1227. [CrossRef]

296. Merlini, M.; Rafalski, V.A.; Rios Coronado, P.E.; Gill, T.M.; Ellisman, M.; Muthukumar, G.; Subramanian, K.S.; Ryu, J.K.; Syme, C.A.; Davalos, D.; et al. Fibrinogen induces microglia-mediated spine elimination and cognitive impairment in an Alzheimer's disease model. Neuron 2019, 101, 1099-1108.e6. [CrossRef]

297. Nagareddy, P.R.; Kraakman, M.; Masters, S.L.; Stirzaker, R.A.; Gorman, D.J.; Grant, R.W.; Dragoljevic, D.; Hong, E.S.; Abdel-Latif, A.; Smyth, S.S.; et al. Adipose tissue macrophages promote myelopoiesis and monocytosis in obesity. Cell Metab. 2014, 19, 821-835. [CrossRef] [PubMed]

298. Christou, K.A.; Christou, G.A.; Karamoutsios, A.; Vartholomatos, G.; Gartzonika, K.; Tsatsoulis, A.; Tigas, S. Metabolically Healthy Obesity is Characterized by a Proinflammatory Phenotype of Circulating Monocyte Subsets. Metab. Syndr. Relat. Disord. 2019, 17, 259-265. [CrossRef]

299. Friedrich, K.; Sommer, M.; Strobel, S.; Thrum, S.; Bluher, M.; Wagner, U.; Rossol, M. Perturbation of the monocyte compartment in human obesity. Front. Immunol. 2019, 10, 1874. [CrossRef]

300. Satoh, N.; Shimatsu, A.; Himeno, A.; Sasaki, Y.; Yamakage, H.; Yamada, K.; Suganami, T.; Ogawa, Y. Unbalanced M1/M2 phenotype of peripheral blood monocytes in obese diabetic patients: Effect of pioglitazone. Diabetes Care 2010, 33, e7. [CrossRef]

301. Devevre, E.F.; Renovato-Martins, M.; Clement, K.; Sautes-Fridman, C.; Cremer, I.; Poitou, C. Profiling of the three circulating monocyte subpopulations in human obesity. J. Immunol. 2015, 194, 3917-3923. [CrossRef]

302. Alfakry, H.; Malle, E.; Koyani, C.N.; Pussinen, P.J.; Sorsa, T. Neutrophil proteolytic activation cascades: A possible mechanistic link between chronic periodontitis and coronary heart disease. Innate Immun. 2016, 22, 85-99. [CrossRef]

303. Niu, H.; Li, Y.; Li, H.; Chi, Y.; Zhuang, M.; Zhang, T.; Liu, M.; Nie, L. Matrix metalloproteinase 12 modulates high-fat-diet induced glomerular fibrogenesis and inflammation in a mouse model of obesity. Sci. Rep. 2016, 6, 20171. [CrossRef] [PubMed]

304. Fischoeder, A.; Meyborg, H.; Stibenz, D.; Fleck, E.; Graf, K.; Stawowy, P. Insulin augments matrix metalloproteinase-9 expression in monocytes. Cardiovasc. Res. 2007, 73, 841-848. [CrossRef]

305. Sindhu, S.; Al-Roub, A.; Koshy, M.; Thomas, R.; Ahmad, R. Palmitate-induced MMP-9 expression in the human monocytic cells is mediated through the TLR4-MyD88 dependent mechanism. Cell Physiol. Biochem. 2016, 39, 889-900. [CrossRef] [PubMed]

306. Lee, J.T.; Pamir, N.; Liu, N.C.; Kirk, E.A.; Averill, M.M.; Becker, L.; Larson, I.; Hagman, D.K.; Foster-Schubert, K.E.; van Yserloo, B.; et al. Macrophage metalloelastase (MMP12) regulates adipose tissue expansion, insulin sensitivity, and expression of inducible nitric oxide synthase. Endocrinology 2014, 155, 3409-3420. [CrossRef]

307. Behl, T.; Kaur, G.; Sehgal, A.; Bhardwaj, S.; Singh, S.; Buhas, C.; Judea-Pusta, C.; Uivarosan, D.; Munteanu, M.A.; Bungau, S. Multifaceted role of matrix metalloproteinases in neurodegenerative diseases: Pathophysiological and therapeutic perspectives. Int. J. Mol. Sci. 2021, 22, 1413. [CrossRef]

308. Kouwenhoven, M.; Ozenci, V.; Gomes, A.; Yarilin, D.; Giedraitis, V.; Press, R.; Link, H. Multiple sclerosis: Elevated expression of matrix metalloproteinases in blood monocytes. J. Autoimmun. 2001, 16, 463-470. [CrossRef]

309. Ong, C.W.; Pabisiak, P.J.; Brilha, S.; Singh, P.; Roncaroli, F.; Elkington, P.T.; Friedland, J.S. Complex regulation of neutrophil-derived MMP-9 secretion in central nervous system tuberculosis. J. Neuroinflamm. 2017, 14, 31. [CrossRef] [PubMed]

310. Feng, S.; Cen, J.; Huang, Y.; Shen, H.; Yao, L.; Wang, Y.; Chen, Z. Matrix metalloproteinase-2 and -9 secreted by leukemic cells increase the permeability of blood-brain barrier by disrupting tight junction proteins. PLoS ONE 2011, 6, e20599. [CrossRef]

311. Goyal, R.; Faizy, A.F.; Siddiqui, S.S.; Singhai, M. Evaluation of TNF-alpha and IL-6 levels in obese and non-obese diabetics: Pre-and postinsulin effects. N. Am. J. Med. Sci. 2012, 4, 180-184. 
312. Alzamil, H. Elevated serum TNF-alpha is related to obesity in type 2 diabetes mellitus and is associated with glycemic control and insulin resistance. J. Obes. 2020, 2020, 5076858. [CrossRef] [PubMed]

313. Jung, C.; Gerdes, N.; Fritzenwanger, M.; Figulla, H.R. Circulating levels of interleukin-1 family cytokines in overweight adolescents. Mediat. Inflamm. 2010, 2010, 958403. [CrossRef] [PubMed]

314. Shoda, H.; Nagafuchi, Y.; Tsuchida, Y.; Sakurai, K.; Sumitomo, S.; Fujio, K.; Yamamoto, K. Increased serum concentrations of IL-1 beta, IL-21 and Th17 cells in overweight patients with rheumatoid arthritis. Arthritis Res. Ther. 2017, 19, 111. [CrossRef]

315. Knoll, J.G.; Krasnow, S.M.; Marks, D.L. Interleukin-1beta signaling in fenestrated capillaries is sufficient to trigger sickness responses in mice. J. Neuroinflamm. 2017, 14, 219. [CrossRef]

316. Lively, S.; Schlichter, L.C. Microglia responses to pro-inflammatory stimuli (LPS, IFNgamma+TNFalpha) and reprogramming by resolving cytokines (IL-4, IL-10). Front. Cell Neurosci. 2018, 12, 215. [CrossRef]

317. Chen, A.Q.; Fang, Z.; Chen, X.L.; Yang, S.; Zhou, Y.F.; Mao, L.; Xia, Y.P.; Jin, H.J.; Li, Y.N.; You, M.F.; et al. Microglia-derived TNF-alpha mediates endothelial necroptosis aggravating blood brain-barrier disruption after ischemic stroke. Cell Death Dis. 2019, 10, 487. [CrossRef] [PubMed]

318. Guadagno, J.; Xu, X.; Karajgikar, M.; Brown, A.; Cregan, S.P. Microglia-derived TNFalpha induces apoptosis in neural precursor cells via transcriptional activation of the Bcl-2 family member Puma. Cell Death Dis. 2013, 4, e538. [CrossRef]

319. Rothaug, M.; Becker-Pauly, C.; Rose-John, S. The role of interleukin-6 signaling in nervous tissue. Biochim. Biophys. Acta 2016, 1863 (Pt 6), 1218-1227. [CrossRef]

320. Hunter, C.A.; Jones, S.A. IL-6 as a keystone cytokine in health and disease. Nat. Immunol. 2015, 16, 448-457. [CrossRef]

321. Tapia-Gonzalez, S.; Garcia-Segura, L.M.; Tena-Sempere, M.; Frago, L.M.; Castellano, J.M.; Fuente-Martin, E.; Garcia-Caceres, C.; Argente, J.; Chowen, J.A. Activation of microglia in specific hypothalamic nuclei and the cerebellum of adult rats exposed to neonatal overnutrition. J. Neuroendocrinol. 2011, 23, 365-370. [CrossRef] [PubMed]

322. Recasens, M.; Almolda, B.; Perez-Clausell, J.; Campbell, I.L.; Gonzalez, B.; Castellano, B. Chronic exposure to IL-6 induces a desensitized phenotype of the microglia. J. Neuroinflamm. 2021, 18, 31. [CrossRef] [PubMed]

323. Gyengesi, E.; Rangel, A.; Ullah, F.; Liang, H.; Niedermayer, G.; Asgarov, R.; Venigalla, M.; Gunawardena, D.; Karl, T.; Munch, G. Chronic microglial activation in the GFAP-IL6 mouse contributes to age-dependent cerebellar volume loss and impairment in motor function. Front. Neurosci. 2019, 13, 303. [CrossRef]

324. Wallenius, V.; Wallenius, K.; Ahren, B.; Rudling, M.; Carlsten, H.; Dickson, S.L.; Ohlsson, C.; Jansson, J.O. Interleukin-6-deficient mice develop mature-onset obesity. Nat. Med. 2002, 8, 75-79. [CrossRef] [PubMed]

325. Mishra, D.; Richard, J.E.; Maric, I.; Porteiro, B.; Haring, M.; Kooijman, S.; Musovic, S.; Eerola, K.; Lopez-Ferreras, L.; Peris, E.; et al Parabrachial interleukin-6 reduces body weight and food intake and increases thermogenesis to regulate energy metabolism. Cell Rep. 2019, 26, 3011-3026.e5. [CrossRef]

326. Ropelle, E.R.; Flores, M.B.; Cintra, D.E.; Rocha, G.Z.; Pauli, J.R.; Morari, J.; de Souza, C.T.; Moraes, J.C.; Prada, P.O.; Guadagnini, D.; et al. IL-6 and IL-10 anti-inflammatory activity links exercise to hypothalamic insulin and leptin sensitivity through IKKbeta and ER stress inhibition. PLoS Biol. 2010, 8, e1000465. [CrossRef]

327. Funk, J.A.; Gohlke, J.; Kraft, A.D.; McPherson, C.A.; Collins, J.B.; Jean Harry, G. Voluntary exercise protects hippocampal neurons from trimethyltin injury: Possible role of interleukin-6 to modulate tumor necrosis factor receptor-mediated neurotoxicity. Brain Behav. Immun. 2011, 25, 1063-1077. [CrossRef] [PubMed]

328. Willis, E.F.; MacDonald, K.P.A.; Nguyen, Q.H.; Garrido, A.L.; Gillespie, E.R.; Harley, S.B.R.; Bartlett, P.F.; Schroder, W.A.; Yates, A.G.; Anthony, D.C.; et al. Repopulating microglia promote brain repair in an IL-6-dependent manner. Cell 2020, 180, 833-846.e16. [CrossRef]

329. Ahima, R.S.; Flier, J.S. Leptin. Annu. Rev. Physiol. 2000, 62, 413-437. [CrossRef]

330. Zhao, S.; Kusminski, C.M.; Elmquist, J.K.; Scherer, P.E. Leptin: Less is more. Diabetes 2020, 69, 823-829. [CrossRef]

331. Caron, A.; Lee, S.; Elmquist, J.K.; Gautron, L. Leptin and brain-adipose crosstalks. Nat. Rev. Neurosci. 2018, 19, 153-165. [CrossRef] [PubMed]

332. Fujita, Y.; Yamashita, T. The effects of leptin on glial cells in neurological diseases. Front. Neurosci. 2019, 13, 828. [CrossRef] [PubMed]

333. McGregor, G.; Harvey, J. Leptin regulation of synaptic function at hippocampal TA-CA1 and SC-CA1 synapses: Implications for health and disease. Neurochem. Res. 2019, 44, 650-660. [CrossRef] [PubMed]

334. Achari, A.E.; Jain, S.K. Adiponectin, a therapeutic target for obesity, diabetes, and endothelial dysfunction. Int. J. Mol. Sci. 2017, 18, 1321. [CrossRef]

335. Liu, Y.; Palanivel, R.; Rai, E.; Park, M.; Gabor, T.V.; Scheid, M.P.; Xu, A.; Sweeney, G. Adiponectin stimulates autophagy and reduces oxidative stress to enhance insulin sensitivity during high-fat diet feeding in mice. Diabetes 2015, 64, 36-48. [CrossRef]

336. Kusminski, C.M.; McTernan, P.G.; Schraw, T.; Kos, K.; O’Hare, J.P.; Ahima, R.; Kumar, S.; Scherer, P.E. Adiponectin complexes in human cerebrospinal fluid: Distinct complex distribution from serum. Diabetologia 2007, 50, 634-642. [CrossRef]

337. Liu, J.; Guo, M.; Zhang, D.; Cheng, S.Y.; Liu, M.; Ding, J.; Scherer, P.E.; Liu, F.; Lu, X.Y. Adiponectin is critical in determining susceptibility to depressive behaviors and has antidepressant-like activity. Proc. Natl. Acad. Sci. USA 2012, 109, 12248-12253. [CrossRef]

338. Qi, Y.; Takahashi, N.; Hileman, S.M.; Patel, H.R.; Berg, A.H.; Pajvani, U.B.; Scherer, P.E.; Ahima, R.S. Adiponectin acts in the brain to decrease body weight. Nat. Med. 2004, 10, 524-529. [CrossRef] 
339. Yau, S.Y.; Li, A.; Hoo, R.L.; Ching, Y.P.; Christie, B.R.; Lee, T.M.; Xu, A.; So, K.F. Physical exercise-induced hippocampal neurogenesis and antidepressant effects are mediated by the adipocyte hormone adiponectin. Proc. Natl. Acad. Sci. USA 2014, 111, 15810-15815. [CrossRef]

340. Lee, H.; Tu, T.H.; Park, B.S.; Yang, S.; Kim, J.G. Adiponectin reverses the hypothalamic microglial inflammation during short-term exposure to fat-rich diet. Int. J. Mol. Sci. 2019, 20, 5738. [CrossRef]

341. Ng, R.C.; Cheng, O.Y.; Jian, M.; Kwan, J.S.; Ho, P.W.; Cheng, K.K.; Yeung, P.K.; Zhou, L.L.; Hoo, R.L.; Chung, S.K.; et al. Chronic adiponectin deficiency leads to Alzheimer's disease-like cognitive impairments and pathologies through AMPK inactivation and cerebral insulin resistance in aged mice. Mol. Neurodegener. 2016, 11, 71. [CrossRef]

342. Ng, R.C.; Jian, M.; Ma, O.K.; Bunting, M.; Kwan, J.S.; Zhou, G.J.; Senthilkumar, K.; Iyaswamy, A.; Chan, P.K.; Li, M.; et al. Chronic oral administration of adipoRon reverses cognitive impairments and ameliorates neuropathology in an Alzheimer's disease mouse model. Mol. Psychiatry 2020. [CrossRef] [PubMed]

343. Chabry, J.; Nicolas, S.; Cazareth, J.; Murris, E.; Guyon, A.; Glaichenhaus, N.; Heurteaux, C.; Petit-Paitel, A. Enriched environment decreases microglia and brain macrophages inflammatory phenotypes through adiponectin-dependent mechanisms: Relevance to depressive-like behavior. Brain Behav. Immun. 2015, 50, 275-287. [CrossRef] [PubMed]

344. Nicolas, S.; Veyssiere, J.; Gandin, C.; Zsurger, N.; Pietri, M.; Heurteaux, C.; Glaichenhaus, N.; Petit-Paitel, A.; Chabry, J. Neurogenesis-independent antidepressant-like effects of enriched environment is dependent on adiponectin. Psychoneuroendocrinology 2015, 57, 72-83. [CrossRef]

345. Nicolas, S.; Cazareth, J.; Zarif, H.; Guyon, A.; Heurteaux, C.; Chabry, J.; Petit-Paitel, A. Globular adiponectin limits microglia pro-inflammatory phenotype through an AdipoR1/NF-kappaB signaling pathway. Front. Cell Neurosci. 2017, 11, 352. [CrossRef]

346. Song, J.; Choi, S.M.; Kim, B.C. Adiponectin regulates the polarization and function of microglia via PPAR-gamma signaling under amyloid beta toxicity. Front. Cell Neurosci. 2017, 11, 64. [CrossRef]

347. Jian, M.; Kwan, J.S.; Bunting, M.; Ng, R.C.; Chan, K.H. Adiponectin suppresses amyloid-beta oligomer (AbetaO)-induced inflammatory response of microglia via AdipoR1-AMPK-NF-kappaB signaling pathway. J. Neuroinflamm. 2019, 16, 110. [CrossRef] [PubMed]

348. Zheng, J.; Sun, Z.; Liang, F.; Xu, W.; Lu, J.; Shi, L.; Shao, A.; Yu, J.; Zhang, J. AdipoRon attenuates neuroinflammation after intracerebral hemorrhage through AdipoR1-AMPK pathway. Neuroscience 2019, 412, 116-130. [CrossRef] [PubMed]

349. Zhao, L.; Chen, S.; Sherchan, P.; Ding, Y.; Zhao, W.; Guo, Z.; Yu, J.; Tang, J.; Zhang, J.H. Recombinant CTRP9 administration attenuates neuroinflammation via activating adiponectin receptor 1 after intracerebral hemorrhage in mice. J. Neuroinflamm. 2018, 15, 215. [CrossRef] [PubMed]

350. Hahm, J.R.; Jo, M.H.; Ullah, R.; Kim, M.W.; Kim, M.O. Metabolic stress alters antioxidant systems, suppresses the adiponectin receptor 1 and induces Alzheimer's like pathology in mice brain. Cells 2020, 9, 249. [CrossRef]

351. Bays, H.E.; Toth, P.P.; Kris-Etherton, P.M.; Abate, N.; Aronne, L.J.; Brown, W.V.; Gonzalez-Campoy, J.M.; Jones, S.R.; Kumar, R.; La Forge, R.; et al. Obesity, adiposity, and dyslipidemia: A consensus statement from the National Lipid Association. J. Clin. Lipidol. 2013, 7, 304-383. [CrossRef] [PubMed]

352. Zhou, H.; Urso, C.J.; Jadeja, V. Saturated fatty acids in obesity-associated inflammation. J. Inflamm. Res. 2020, 13, 1-14. [CrossRef]

353. Zhao, L.; Ni, Y.; Ma, X.; Zhao, A.; Bao, Y.; Liu, J.; Chen, T.; Xie, G.; Panee, J.; Su, M.; et al. A panel of free fatty acid ratios to predict the development of metabolic abnormalities in healthy obese individuals. Sci. Rep. 2016, 6, 28418. [CrossRef]

354. Dumas, J.A.; Bunn, J.Y.; Nickerson, J.; Crain, K.I.; Ebenstein, D.B.; Tarleton, E.K.; Makarewicz, J.; Poynter, M.E.; Kien, C.L. Dietary saturated fat and monounsaturated fat have reversible effects on brain function and the secretion of pro-inflammatory cytokines in young women. Metabolism 2016, 65, 1582-1588. [CrossRef]

355. Pakiet, A.; Jakubiak, A.; Mierzejewska, P.; Zwara, A.; Liakh, I.; Sledzinski, T.; Mika, A. The effect of a high-fat diet on the fatty acid composition in the hearts of mice. Nutrients 2020, 12, 824. [CrossRef] [PubMed]

356. Tu, T.H.; Kim, H.; Yang, S.; Kim, J.K.; Kim, J.G. Linoleic acid rescues microglia inflammation triggered by saturated fatty acid. Biochem. Biophys. Res. Commun. 2019, 513, 201-206. [CrossRef] [PubMed]

357. Karmi, A.; Iozzo, P.; Viljanen, A.; Hirvonen, J.; Fielding, B.A.; Virtanen, K.; Oikonen, V.; Kemppainen, J.; Viljanen, T.; Guiducci, L.; et al. Increased brain fatty acid uptake in metabolic syndrome. Diabetes 2010, 59, 2171-2177. [CrossRef]

358. Borg, M.L.; Omran, S.F.; Weir, J.; Meikle, P.J.; Watt, M.J. Consumption of a high-fat diet, but not regular endurance exercise training, regulates hypothalamic lipid accumulation in mice. J. Physiol. 2012, 590, 4377-4389. [CrossRef]

359. Melo, H.M.; Seixas da Silva, G.D.S.; Sant'Ana, M.R.; Teixeira, C.V.L.; Clarke, J.R.; Miya Coreixas, V.S.; de Melo, B.C.; Fortuna, J.T.S.; Forny-Germano, L.; Ledo, J.H.; et al. Palmitate is increased in the cerebrospinal fluid of humans with obesity and induces memory impairment in mice via pro-inflammatory TNF-alpha. Cell Rep. 2020, 30, 2180-2194.e8. [CrossRef]

360. Spinelli, M.; Fusco, S.; Mainardi, M.; Scala, F.; Natale, F.; Lapenta, R.; Mattera, A.; Rinaudo, M.; Li Puma, D.D.; Ripoli, C.; et al. Brain insulin resistance impairs hippocampal synaptic plasticity and memory by increasing GluA1 palmitoylation through FoxO3a. Nat. Commun. 2017, 8, 2009. [CrossRef]

361. Morselli, E.; Fuente-Martin, E.; Finan, B.; Kim, M.; Frank, A.; Garcia-Caceres, C.; Navas, C.R.; Gordillo, R.; Neinast, M.; Kalainayakan, S.P.; et al. Hypothalamic PGC-1alpha protects against high-fat diet exposure by regulating ERalpha. Cell Rep. 2014, 9, 633-645. [CrossRef] [PubMed] 
362. Marwarha, G.; Claycombe, K.; Schommer, J.; Collins, D.; Ghribi, O. Palmitate-induced endoplasmic reticulum stress and subsequent C/EBPalpha Homologous Protein activation attenuates leptin and Insulin-like growth factor 1 expression in the brain. Cell Sign. 2016, 28, 1789-1805. [CrossRef] [PubMed]

363. Plociennikowska, A.; Hromada-Judycka, A.; Borzecka, K.; Kwiatkowska, K. Co-operation of TLR4 and raft proteins in LPSinduced pro-inflammatory signaling. Cell. Mol. Life Sci. 2015, 72, 557-581. [CrossRef] [PubMed]

364. Bosetti, F. Arachidonic acid metabolism in brain physiology and pathology: Lessons from genetically altered mouse models. J. Neurochem. 2007, 102, 577-586. [CrossRef]

365. Simopoulos, A.P. Evolutionary aspects of diet: The omega-6/omega-3 ratio and the brain. Mol. Neurobiol. 2011, 44, 203-215. [CrossRef]

366. Serhan, C.N.; Chiang, N. Resolution phase lipid mediators of inflammation: Agonists of resolution. Curr. Opin. Pharmacol. 2013, 13, 632-640. [CrossRef]

367. Hjorth, E.; Zhu, M.; Toro, V.C.; Vedin, I.; Palmblad, J.; Cederholm, T.; Freund-Levi, Y.; Faxen-Irving, G.; Wahlund, L.O.; Basun, H.; et al. Omega-3 fatty acids enhance phagocytosis of Alzheimer's disease-related amyloid-beta42 by human microglia and decrease inflammatory markers. J. Alzheimers Dis. 2013, 35, 697-713. [CrossRef]

368. Ma, Q.L.; Zhu, C.; Morselli, M.; Su, T.; Pelligrini, M.; Lu, Z.; Jones, M.; Denver, P.; Castro, D.; Gu, X.; et al. The novel omega-6 fatty acid docosapentaenoic acid positively modulates brain innate immune response for resolving neuroinflammation at early and late stages of humanized APOE-based Alzheimer's disease Models. Front. Immunol. 2020, 11, 558036. [CrossRef]

369. Chen, X.; Wu, S.; Chen, C.; Xie, B.; Fang, Z.; Hu, W.; Chen, J.; Fu, H.; He, H. Omega-3 polyunsaturated fatty acid supplementation attenuates microglial-induced inflammation by inhibiting the HMGB1/TLR4/NF-kappaB pathway following experimental traumatic brain injury. J. Neuroinflamm. 2017, 14, 143. [CrossRef]

370. Chen, X.; Chen, C.; Fan, S.; Wu, S.; Yang, F.; Fang, Z.; Fu, H.; Li, Y. Omega-3 polyunsaturated fatty acid attenuates the inflammatory response by modulating microglia polarization through SIRT1-mediated deacetylation of the HMGB1/NF-kappaB pathway following experimental traumatic brain injury. J. Neuroinflamm. 2018, 15, 116. [CrossRef]

371. Chen, S.; Zhang, H.; Pu, H.; Wang, G.; Li, W.; Leak, R.K.; Chen, J.; Liou, A.K.; Hu, X. n-3 PUFA supplementation benefits microglial responses to myelin pathology. Sci. Rep. 2014, 4, 7458. [CrossRef]

372. Chen, W.; Balland, E.; Cowley, M.A. Hypothalamic insulin resistance in obesity: Effects on glucose homeostasis. Neuroendocrinology 2017, 104, 364-381. [CrossRef] [PubMed]

373. Lee, S.; Joo, Y.J.; Kim, R.Y.; Hwang, J.; Lim, S.M.; Yoon, S.; Kim, J. Obesity may connect insulin resistance to decreased neuronal viability in human diabetic brain. Obesity 2020, 28, 1626-1630. [CrossRef] [PubMed]

374. Kullmann, S.; Valenta, V.; Wagner, R.; Tschritter, O.; Machann, J.; Haring, H.U.; Preissl, H.; Fritsche, A.; Heni, M. Brain insulin sensitivity is linked to adiposity and body fat distribution. Nat. Commun. 2020, 11, 1841. [CrossRef]

375. Maher, P.A.; Schubert, D.R. Metabolic links between diabetes and Alzheimer's disease. Expert Rev. Neurother. 2009, 9, 617-630. [CrossRef]

376. Fishel, M.A.; Watson, G.S.; Montine, T.J.; Wang, Q.; Green, P.S.; Kulstad, J.J.; Cook, D.G.; Peskind, E.R.; Baker, L.D.; Goldgaber, D.; et al. Hyperinsulinemia provokes synchronous increases in central inflammation and beta-amyloid in normal adults. Arch. Neurol. 2005, 62, 1539-1544. [CrossRef] [PubMed]

377. Ho, L.; Qin, W.; Pompl, P.N.; Xiang, Z.; Wang, J.; Zhao, Z.; Peng, Y.; Cambareri, G.; Rocher, A.; Mobbs, C.V.; et al. Diet-induced insulin resistance promotes amyloidosis in a transgenic mouse model of Alzheimer's disease. FASEB J. 2004, 18, 902-904. [CrossRef]

378. Takeda, S.; Sato, N.; Uchio-Yamada, K.; Sawada, K.; Kunieda, T.; Takeuchi, D.; Kurinami, H.; Shinohara, M.; Rakugi, H.; Morishita, R. Diabetes-accelerated memory dysfunction via cerebrovascular inflammation and Abeta deposition in an Alzheimer mouse model with diabetes. Proc. Natl. Acad. Sci. USA 2010, 107, 7036-7041. [CrossRef]

379. Dinel, A.L.; Andre, C.; Aubert, A.; Ferreira, G.; Laye, S.; Castanon, N. Cognitive and emotional alterations are related to hippocampal inflammation in a mouse model of metabolic syndrome. PLoS ONE 2011, 6, e24325. [CrossRef]

380. Pistell, P.J.; Morrison, C.D.; Gupta, S.; Knight, A.G.; Keller, J.N.; Ingram, D.K.; Bruce-Keller, A.J. Cognitive impairment following high fat diet consumption is associated with brain inflammation. J. Neuroimmunol. 2010, 219, 25-32. [CrossRef]

381. Wang, L.; Zhai, Y.Q.; Xu, L.L.; Qiao, C.; Sun, X.L.; Ding, J.H.; Lu, M.; Hu, G. Metabolic inflammation exacerbates dopaminergic neuronal degeneration in response to acute MPTP challenge in type 2 diabetes mice. Exp. Neurol. 2014, 251, 22-29. [CrossRef] [PubMed]

382. Haas, C.B.; de Carvalho, A.K.; Muller, A.P.; Eggen, B.J.L.; Portela, L.V. Insulin activates microglia and increases COX-2/IL-1beta expression in young but not in aged hippocampus. Brain Res. 2020, 1741, 146884. [CrossRef]

383. Ieronymaki, E.; Theodorakis, E.M.; Lyroni, K.; Vergadi, E.; Lagoudaki, E.; Al-Qahtani, A.; Aznaourova, M.; Neofotistou-Themeli, E.; Eliopoulos, A.G.; Vaporidi, K.; et al. Insulin resistance in macrophages alters their metabolism and promotes an M2-like phenotype. J. Immunol. 2019, 202, 1786-1797. [CrossRef] [PubMed]

384. Galitzky, J.; Bouloumie, A. Human visceral-fat-specific glucocorticoid tuning of adipogenesis. Cell Metab. 2013, 18, 3-5. [CrossRef]

385. Mateska, I.; Nanda, K.; Dye, N.A.; Alexaki, V.I.; Eaton, S. Range of SHH signaling in adrenal gland is limited by membrane contact to cells with primary cilia. J. Cell Biol. 2020, 219, e201910087. [CrossRef] 
386. Steffensen, C.; Dekkers, O.M.; Lyhne, J.; Pedersen, B.G.; Rasmussen, F.; Rungby, J.; Poulsen, P.L.; Jorgensen, J.O.L. Hypercortisolism in Newly Diagnosed Type 2 Diabetes: A Prospective Study of 384 Newly Diagnosed Patients. Horm. Metab. Res. 2019, $51,62-68$. [CrossRef] [PubMed]

387. Yau, S.Y.; Lau, B.W.; Tong, J.B.; Wong, R.; Ching, Y.P.; Qiu, G.; Tang, S.W.; Lee, T.M.; So, K.F. Hippocampal neurogenesis and dendritic plasticity support running-improved spatial learning and depression-like behaviour in stressed rats. PLoS ONE 2011, 6 , e24263. [CrossRef]

388. Brummelte, S.; Galea, L.A. Chronic high corticosterone reduces neurogenesis in the dentate gyrus of adult male and female rats. Neuroscience 2010, 168, 680-690. [CrossRef]

389. Park, H.J.; Lee, S.; Jung, J.W.; Kim, B.C.; Ryu, J.H.; Kim, D.H. Glucocorticoid- and long-term stress-induced aberrant synaptic plasticity are mediated by activation of the glucocorticoid receptor. Arch. Pharm. Res. 2015, 38, 1204-1212. [CrossRef]

390. Coutinho, A.E.; Chapman, K.E. The anti-inflammatory and immunosuppressive effects of glucocorticoids, recent developments and mechanistic insights. Mol. Cell. Endocrinol. 2011, 335, 2-13. [CrossRef]

391. Munhoz, C.D.; Sorrells, S.F.; Caso, J.R.; Scavone, C.; Sapolsky, R.M. Glucocorticoids exacerbate lipopolysaccharide-induced signaling in the frontal cortex and hippocampus in a dose-dependent manner. J. Neurosci. 2010, 30, 13690-13698. [CrossRef]

392. Munhoz, C.D.; Lepsch, L.B.; Kawamoto, E.M.; Malta, M.B.; Lima Lde, S.; Avellar, M.C.; Sapolsky, R.M.; Scavone, C. Chronic unpredictable stress exacerbates lipopolysaccharide-induced activation of nuclear factor-kappaB in the frontal cortex and hippocampus via glucocorticoid secretion. J. Neurosci. 2006, 26, 3813-3820. [CrossRef]

393. Garcia-Bueno, B.; Madrigal, J.L.; Perez-Nievas, B.G.; Leza, J.C. Stress mediators regulate brain prostaglandin synthesis and peroxisome proliferator-activated receptor-gamma activation after stress in rats. Endocrinology 2008, 149, 1969-1978. [CrossRef]

394. Sierra, A.; Gottfried-Blackmore, A.; Milner, T.A.; McEwen, B.S.; Bulloch, K. Steroid hormone receptor expression and function in microglia. Glia 2008, 56, 659-674. [CrossRef]

395. Carrillo-de Sauvage, M.A.; Maatouk, L.; Arnoux, I.; Pasco, M.; Sanz Diez, A.; Delahaye, M.; Herrero, M.T.; Newman, T.A.; Calvo, C.F.; Audinat, E.; et al. Potent and multiple regulatory actions of microglial glucocorticoid receptors during CNS inflammation. Cell Death Differ. 2013, 20, 1546-1557. [CrossRef] [PubMed]

396. Frank, M.G.; Fonken, L.K.; Watkins, L.R.; Maier, S.F. Microglia: Neuroimmune-sensors of stress. Semin. Cell Dev. Biol. 2019, 94, 176-185. [CrossRef]

397. Sanguino-Gomez, J.; Buurstede, J.C.; Abiega, O.; Fitzsimons, C.P.; Lucassen, P.J.; Eggen, B.J.L.; Lesuis, S.L.; Meijer, O.C.; Krugers, H.J. An emerging role for microglia in stress-effects on memory. Eur. J. Neurosci. 2021. [CrossRef] [PubMed]

398. De Pablos, R.M.; Villaran, R.F.; Arguelles, S.; Herrera, A.J.; Venero, J.L.; Ayala, A.; Cano, J.; Machado, A. Stress increases vulnerability to inflammation in the rat prefrontal cortex. J. Neurosci. 2006, 26, 5709-5719. [CrossRef] [PubMed]

399. Pedrazzoli, M.; Losurdo, M.; Paolone, G.; Medelin, M.; Jaupaj, L.; Cisterna, B.; Slanzi, A.; Malatesta, M.; Coco, S.; Buffelli, M. Glucocorticoid receptors modulate dendritic spine plasticity and microglia activity in an animal model of Alzheimer's disease. Neurobiol. Dis. 2019, 132, 104568. [CrossRef]

400. Hoeijmakers, L.; Ruigrok, S.R.; Amelianchik, A.; Ivan, D.; van Dam, A.M.; Lucassen, P.J.; Korosi, A. Early-life stress lastingly alters the neuroinflammatory response to amyloid pathology in an Alzheimer's disease mouse model. Brain Behav. Immun. 2017, 63, 160-175. [CrossRef]

401. Catale, C.; Gironda, S.; Lo Iacono, L.; Carola, V. Microglial function in the effects of early-life stress on brain and behavioral development. J. Clin. Med. 2020, 9, 468. [CrossRef] [PubMed]

402. Dey, A.; Hao, S.; Erion, J.R.; Wosiski-Kuhn, M.; Stranahan, A.M. Glucocorticoid sensitization of microglia in a genetic mouse model of obesity and diabetes. J. Neuroimmunol. 2014, 269, 20-27. [CrossRef] [PubMed]

403. Stranahan, A.M.; Arumugam, T.V.; Mattson, M.P. Lowering corticosterone levels reinstates hippocampal brain-derived neurotropic factor and Trkb expression without influencing deficits in hypothalamic brain-derived neurotropic factor expression in leptin receptor-deficient mice. Neuroendocrinology 2011, 93, 58-64. [CrossRef] [PubMed]

404. Wosiski-Kuhn, M.; Erion, J.R.; Gomez-Sanchez, E.P.; Gomez-Sanchez, C.E.; Stranahan, A.M. Glucocorticoid receptor activation impairs hippocampal plasticity by suppressing BDNF expression in obese mice. Psychoneuroendocrinology 2014, 42, 165-177. [CrossRef]

405. Frank, M.G.; Baratta, M.V.; Sprunger, D.B.; Watkins, L.R.; Maier, S.F. Microglia serve as a neuroimmune substrate for stressinduced potentiation of CNS pro-inflammatory cytokine responses. Brain Behav. Immun. 2007, 21, 47-59. [CrossRef]

406. Frank, M.G.; Thompson, B.M.; Watkins, L.R.; Maier, S.F. Glucocorticoids mediate stress-induced priming of microglial proinflammatory responses. Brain Behav. Immun. 2012, 26, 337-345. [CrossRef]

407. Duque Ede, A.; Munhoz, C.D. The pro-inflammatory effects of glucocorticoids in the brain. Front. Endocrinol. 2016, 7, 78. [CrossRef]

408. Lim, H.Y.; Muller, N.; Herold, M.J.; van den Brandt, J.; Reichardt, H.M. Glucocorticoids exert opposing effects on macrophage function dependent on their concentration. Immunology 2007, 122, 47-53. [CrossRef]

409. Dhabhar, F.S.; McEwen, B.S. Enhancing versus suppressive effects of stress hormones on skin immune function. Proc. Natl. Acad. Sci. USA 1999, 96, 1059-1064. [CrossRef]

410. Quatrini, L.; Ugolini, S. New insights into the cell- and tissue-specificity of glucocorticoid actions. Cell. Mol. Immunol. 2020, 18, 269-278. [CrossRef] 
411. Tilg, H.; Zmora, N.; Adolph, T.E.; Elinav, E. The intestinal microbiota fuelling metabolic inflammation. Nat. Rev. Immunol. 2020, 20, 40-54. [CrossRef] [PubMed]

412. Le Chatelier, E.; Nielsen, T.; Qin, J.; Prifti, E.; Hildebrand, F.; Falony, G.; Almeida, M.; Arumugam, M.; Batto, J.M.; Kennedy, S.; et al. Richness of human gut microbiome correlates with metabolic markers. Nature 2013, 500, 541-546. [CrossRef] [PubMed]

413. Wu, G.D.; Chen, J.; Hoffmann, C.; Bittinger, K.; Chen, Y.Y.; Keilbaugh, S.A.; Bewtra, M.; Knights, D.; Walters, W.A.; Knight, R.; et al. Linking long-term dietary patterns with gut microbial enterotypes. Science 2011, 334, 105-108. [CrossRef] [PubMed]

414. Ridaura, V.K.; Faith, J.J.; Rey, F.E.; Cheng, J.; Duncan, A.E.; Kau, A.L.; Griffin, N.W.; Lombard, V.; Henrissat, B.; Bain, J.R.; et al. Gut microbiota from twins discordant for obesity modulate metabolism in mice. Science 2013, 341, 1241214. [CrossRef]

415. Backhed, F.; Manchester, J.K.; Semenkovich, C.F.; Gordon, J.I. Mechanisms underlying the resistance to diet-induced obesity in germ-free mice. Proc. Natl. Acad. Sci. USA 2007, 104, 979-984. [CrossRef]

416. Rabot, S.; Membrez, M.; Bruneau, A.; Gerard, P.; Harach, T.; Moser, M.; Raymond, F.; Mansourian, R.; Chou, C.J. Germ-free C57BL/6J mice are resistant to high-fat-diet-induced insulin resistance and have altered cholesterol metabolism. FASEB J. 2010, 24, 4948-4959.

417. Fung, T.C.; Olson, C.A.; Hsiao, E.Y. Interactions between the microbiota, immune and nervous systems in health and disease. Nat. Neurosci. 2017, 20, 145-155. [CrossRef]

418. Bischoff, S.C.; Barbara, G.; Buurman, W.; Ockhuizen, T.; Schulzke, J.D.; Serino, M.; Tilg, H.; Watson, A.; Wells, J.M. Intestinal permeability-a new target for disease prevention and therapy. BMC Gastroenterol. 2014, 14, 189. [CrossRef]

419. Shi, H.; Wang, Q.; Zheng, M.; Hao, S.; Lum, J.S.; Chen, X.; Huang, X.F.; Yu, Y.; Zheng, K. Supplement of microbiota-accessible carbohydrates prevents neuroinflammation and cognitive decline by improving the gut microbiota-brain axis in diet-induced obese mice. J. Neuroinflamm. 2020, 17, 77. [CrossRef]

420. Chen, J.; Haase, N.; Haange, S.B.; Sucher, R.; Munzker, J.; Jager, E.; Schischke, K.; Seyfried, F.; von Bergen, M.; Hankir, M.K.; et al. Roux-en-Y gastric bypass contributes to weight loss-independent improvement in hypothalamic inflammation and leptin sensitivity through gut-microglia-neuron-crosstalk. Mol. Metab. 2021, 48, 101214. [CrossRef] [PubMed]

421. D’Mello, C.; Ronaghan, N.; Zaheer, R.; Dicay, M.; Le, T.; MacNaughton, W.K.; Surrette, M.G.; Swain, M.G. Probiotics improve inflammation-associated sickness behavior by altering communication between the peripheral immune system and the brain. $J$. Neurosci. 2015, 35, 10821-10830. [CrossRef]

422. Shi, H.; Yu, Y.; Lin, D.; Zheng, P.; Zhang, P.; Hu, M.; Wang, Q.; Pan, W.; Yang, X.; Hu, T.; et al. beta-glucan attenuates cognitive impairment via the gut-brain axis in diet-induced obese mice. Microbiome 2020, 8, 143. [CrossRef] [PubMed]

423. Jangi, S.; Gandhi, R.; Cox, L.M.; Li, N.; von Glehn, F.; Yan, R.; Patel, B.; Mazzola, M.A.; Liu, S.; Glanz, B.L.; et al. Alterations of the human gut microbiome in multiple sclerosis. Nat. Commun. 2016, 7, 12015. [CrossRef]

424. Keshavarzian, A.; Green, S.J.; Engen, P.A.; Voigt, R.M.; Naqib, A.; Forsyth, C.B.; Mutlu, E.; Shannon, K.M. Colonic bacterial composition in Parkinson's disease. Mov. Disord. 2015, 30, 1351-1360. [CrossRef] [PubMed]

425. Jiang, H.; Ling, Z.; Zhang, Y.; Mao, H.; Ma, Z.; Yin, Y.; Wang, W.; Tang, W.; Tan, Z.; Shi, J.; et al. Altered fecal microbiota composition in patients with major depressive disorder. Brain Behav. Immun. 2015, 48, 186-194. [CrossRef]

426. Kaiser, T.; Feng, G. Tmem119-EGFP and Tmem119-CreERT2 transgenic mice for labeling and manipulating microglia. eNeuro 2019, 6. [CrossRef]

427. Goldmann, T.; Wieghofer, P.; Muller, P.F.; Wolf, Y.; Varol, D.; Yona, S.; Brendecke, S.M.; Kierdorf, K.; Staszewski, O.; Datta, M.; et al. A new type of microglia gene targeting shows TAK1 to be pivotal in CNS autoimmune inflammation. Nat. Neurosci. 2013, 16, 1618-1626. [CrossRef]

428. McKinsey, G.L.; Lizama, C.O.; Keown-Lang, A.E.; Niu, A.; Santander, N.; Larpthaveesarp, A.; Chee, E.; Gonzalez, F.F.; Arnold, T.D. A new genetic strategy for targeting microglia in development and disease. Elife 2020, 9, e54590. [CrossRef]

429. Bohlen, C.J.; Bennett, F.C.; Tucker, A.F.; Collins, H.Y.; Mulinyawe, S.B.; Barres, B.A. Diverse requirements for microglial survival, specification, and function revealed by defined-medium cultures. Neuron 2017, 94, 759-773.e8. [CrossRef]

430. Delbridge, A.R.D.; Huh, D.; Brickelmaier, M.; Burns, J.C.; Roberts, C.; Challa, R.; Raymond, N.; Cullen, P.; Carlile, T.M.; Ennis, K.A.; et al. Organotypic brain slice culture microglia exhibit molecular similarity to acutely-isolated adult microglia and provide a platform to study neuroinflammation. Front. Cell Neurosci. 2020, 14, 592005. [CrossRef]

431. Han, J.; Zhu, K.; Zhang, X.M.; Harris, R.A. Enforced microglial depletion and repopulation as a promising strategy for the treatment of neurological disorders. Glia 2019, 67, 217-231. [CrossRef]

432. Nissen, J.C.; Thompson, K.K.; West, B.L.; Tsirka, S.E. Csf1R inhibition attenuates experimental autoimmune encephalomyelitis and promotes recovery. Exp. Neurol. 2018, 307, 24-36. [CrossRef]

433. Beckmann, N.; Giorgetti, E.; Neuhaus, A.; Zurbruegg, S.; Accart, N.; Smith, P.; Perdoux, J.; Perrot, L.; Nash, M.; Desrayaud, S.; et al. Brain region-specific enhancement of remyelination and prevention of demyelination by the CSF1R kinase inhibitor BLZ945. Acta Neuropathol. Commun. 2018, 6, 9. [CrossRef]

434. Acharya, M.M.; Green, K.N.; Allen, B.D.; Najafi, A.R.; Syage, A.; Minasyan, H.; Le, M.T.; Kawashita, T.; Giedzinski, E.; Parihar, V.K.; et al. Elimination of microglia improves cognitive function following cranial irradiation. Sci. Rep. 2016, 6, 31545. [CrossRef]

435. Ali, S.; Mansour, A.G.; Huang, W.; Queen, N.J.; Mo, X.; Anderson, J.M.; Hassan, Q.N., 2nd; Patel, R.S.; Wilkins, R.K.; Caligiuri, M.A.; et al. CSF1R inhibitor PLX5622 and environmental enrichment additively improve metabolic outcomes in middle-aged female mice. Aging 2020, 12, 2101-2122. [CrossRef] 
436. Spangenberg, E.E.; Lee, R.J.; Najafi, A.R.; Rice, R.A.; Elmore, M.R.; Blurton-Jones, M.; West, B.L.; Green, K.N. Eliminating microglia in Alzheimer's mice prevents neuronal loss without modulating amyloid-beta pathology. Brain 2016, 139 Pt 4, 1265-1281. [CrossRef]

437. Zhao, R.; Hu, W.; Tsai, J.; Li, W.; Gan, W.B. Microglia limit the expansion of beta-amyloid plaques in a mouse model of Alzheimer's disease. Mol. Neurodegener. 2017, 12, 47. [CrossRef]

438. Wheeler, D.L.; Sariol, A.; Meyerholz, D.K.; Perlman, S. Microglia are required for protection against lethal coronavirus encephalitis in mice. J. Clin. Investig. 2018, 128, 931-943. [CrossRef] [PubMed]

439. Yang, X.; Ren, H.; Wood, K.; Li, M.; Qiu, S.; Shi, F.D.; Ma, C.; Liu, Q. Depletion of microglia augments the dopaminergic neurotoxicity of MPTP. FASEB J. 2018, 32, 3336-3345. [CrossRef]

440. Varvel, N.H.; Grathwohl, S.A.; Baumann, F.; Liebig, C.; Bosch, A.; Brawek, B.; Thal, D.R.; Charo, I.F.; Heppner, F.L.; Aguzzi, A.; et al. Microglial repopulation model reveals a robust homeostatic process for replacing CNS myeloid cells. Proc. Natl. Acad. Sci. USA 2012, 109, 18150-18155. [CrossRef]

441. Scott, C.L.; Zheng, F.; de Baetselier, P.; Martens, L.; Saeys, Y.; de Prijck, S.; Lippens, S.; Abels, C.; Schoonooghe, S.; Raes, G.; et al. Bone marrow-derived monocytes give rise to self-renewing and fully differentiated Kupffer cells. Nat. Commun. 2016, 7, 10321. [CrossRef]

442. Rice, R.A.; Pham, J.; Lee, R.J.; Najafi, A.R.; West, B.L.; Green, K.N. Microglial repopulation resolves inflammation and promotes brain recovery after injury. Glia 2017, 65, 931-944. [CrossRef]

443. Lazaridis, I.; Charalampopoulos, I.; Alexaki, V.I.; Avlonitis, N.; Pediaditakis, I.; Efstathopoulos, P.; Calogeropoulou, T.; Castanas, E.; Gravanis, A. Neurosteroid dehydroepiandrosterone interacts with nerve growth factor (NGF) receptors, preventing neuronal apoptosis. PLoS Biol. 2011, 9, e1001051. [CrossRef]

444. Pediaditakis, I.; Efstathopoulos, P.; Prousis, K.C.; Zervou, M.; Arevalo, J.C.; Alexaki, V.I.; Nikoletopoulou, V.; Karagianni, E.; Potamitis, C.; Tavernarakis, N.; et al. Selective and differential interactions of BNN27, a novel C17-spiroepoxy steroid derivative, with TrkA receptors, regulating neuronal survival and differentiation. Neuropharmacology 2016, 111, 266-282. [CrossRef] [PubMed]

445. Ziogas, A.; Maekawa, T.; Wiessner, J.R.; Le, T.T.; Sprott, D.; Troullinaki, M.; Neuwirth, A.; Anastasopoulou, V.; Grossklaus, S.; Chung, K.J.; et al. DHEA inhibits leukocyte recruitment through regulation of the integrin antagonist DEL-1. J. Immunol. 2020, 204, 1214-1224. [CrossRef]

446. Zhao, N.; Francis, N.L.; Calvelli, H.R.; Moghe, P.V. Microglia-targeting nanotherapeutics for neurodegenerative diseases. APL Bioeng. 2020, 4, 030902. [CrossRef]

447. Kohler, O.; Benros, M.E.; Nordentoft, M.; Farkouh, M.E.; Iyengar, R.L.; Mors, O.; Krogh, J. Effect of anti-inflammatory treatment on depression, depressive symptoms, and adverse effects: A systematic review and meta-analysis of randomized clinical trials. JAMA Psychiatry 2014, 71, 1381-1391. [CrossRef] [PubMed]

448. Raison, C.L.; Rutherford, R.E.; Woolwine, B.J.; Shuo, C.; Schettler, P.; Drake, D.F.; Haroon, E.; Miller, A.H. A randomized controlled trial of the tumor necrosis factor antagonist infliximab for treatment-resistant depression: The role of baseline inflammatory biomarkers. JAMA Psychiatry 2013, 70, 31-41. [CrossRef]

449. Kodama, L.; Gan, L. Do microglial sex differences contribute to sex differences in neurodegenerative diseases? Trends Mol. Med. 2019, 25, 741-749. [CrossRef]

450. Mee-Inta, O.; Zhao, Z.W.; Kuo, Y.M. Physical exercise inhibits inflammation and microglial activation. Cells 2019, 8, 691. [CrossRef] [PubMed]

451. Madore, C.; Yin, Z.; Leibowitz, J.; Butovsky, O. Microglia, Lifestyle stress, and neurodegeneration. Immunity 2020, 52, 222-240. [CrossRef] [PubMed] 